\title{
Daniel Rincon
}

\section{Estudos de DNA Mitocondrial em Populações Remanescentes de Quilombos do Vale do Ribeira - São Paulo.}


Daniel Rincon

\title{
Estudos de DNA Mitocondrial em Populações Remanescentes de Quilombos do Vale do Ribeira - São Paulo.
}

\author{
Dissertação apresentada ao Instituto \\ de Biociências da Universidade de \\ São Paulo, para a obtenção de Título \\ de Mestre em Ciências, na Área de \\ Biologia/Genética.
}

Orientador(a): Profa. Dra. Regina Célia Mingroni Netto

São Paulo

2009 


\section{Ficha Catalográfica}

Rincon, Daniel

Estudos de DNA mitocondrial em

populações remanescentes de quilombos do

Vale do Ribeira - São Paulo.

136p.

Dissertação (Mestrado) - Instituto de Biociências da Universidade de São Paulo.

Departamento de Genética e Biologia Evolutiva.

1. DNA mitocondrial 2.

Variabilidade genética 3. Populações afrobrasileiras 4. Quilombos I. Universidade de São Paulo. Instituto de Biociências.

Departamento de Genética e Biologia Evolutiva.

\section{Comissão Julgadora:}


Ao meu pai, Prof. Dr. Edécio Cunha Netto, fonte de inspiração e meu maior exemplo de dedicação e sucesso na ciência. 
"Is it on his grandfather's or his grandmother's side that Mr. Huxley claims descent from the apes?" (Samuel Wilberforce, Bishop of Oxford).

"As to whether I would prefer to have a miserable ape for a grandfather or a man highly endowed by nature and possessed of great means of influence, and yet who employs those faculties and that influence for the mere purpose of introducing ridicule into a grave scientific discussion, I unhesitatingly affirm my preference for the ape." (T.H. Huxley's reply to Bishop Wilberforce's question).

"If we knew what it was we were doing, it would not be called research, would it?" (Albert Einstein). 


\section{Agradecimentos}

À minha orientadora Profa. Dra. Regina Célia Mingroni Netto, pela paciência, pela dedicação e ensinamentos todos esses anos.

Aos Drs. João Pedro Vicente, Roberto Maluf e Franklin Albert S. Kono, médicos da equipe de pesquisa, pelo exame clínico de todos os indivíduos dos quilombos.

Ao Prof. Dr. Diogo Meyer e seu alunos Rodrigo dos Santos Francisco, Rodrigo Fernandes Ramalho e Kelly Nunes, do Departamento de Genética e Biologia Evolutiva, pelo auxílio e sugestões com as análises populacionais.

À Profa. Dra. Ândrea Kelly Ribeiro dos Santos e seu aluno Bruno Maia Carvalho, da UFPA, pelo inestimável auxílio nas análises de sequências do DNA mitocondrial.

À Maria Teresa B.de M. Auricchio, pela amizade e apoio técnico. Às colegas Lilian Kimura e Claudia B. Angeli, companheiras de viagem e de laboratório, pela agradável companhia.

Aos colegas de trabalho Renata Thieli, Daniela Tiaki, Ana Carla Batissoco, Vitor Dantas, Renata Nonose, Karina Lezirovitz e Ronaldo Serafim, pela amizade, ajuda e incentivo.

À Profa. Dra. Angela Morgante, ao Prof. Dr. Paulo Alberto Otto e todos os colegas do Laboratório de Genética Humana, pelo apoio e agradáveis momentos, com especial atenção aos funcionários Paulo Rogério, Fátima, Mara e Maraísa.

À minha família, minha mãe Lucía e irmãs Paula e Luísa, pelo incentivo e apoio incondicionais e em especial ao meu pai de criação e coração, Prof. Dr. Edécio Cunha Netto, pelo suporte físico e psicológico, sem os quais realizar este trabalho teria sido impossível.

À minha querida Martha Johanna Sepúlveda Flórez, cada vez mais meu principal motivo para olhar o futuro com esperança. Obrigado pelo sincero carinho e amor, pelas descobertas e lições de vida.

Às técnicas de laboratório Maria Cristina Ferreira Costa e Martha Lima Cozzo, pelo auxílio no sequenciamento do DNA.

Aos motoristas do IBUSP, pela competência durante as viagens.

À Maria Ignez Maricondi, do ITESP, e a Rosemeire Saco, do ISA, pela ajuda no levantamento de dados e mapas sobre a área estudada. 
Às irmãs Maria Antonieta Biagioni e Maria Sueli Berlanga, da Casa Pariquial de Eldorado e a Antônio Carlos Nicomedes, do MOAB, pela ajuda no contato com as comunidades.

ÀS prefeituras dos municípios de Eldorado e Iporanga pelo apoio.

Ao CNPq e FAPESP, pelo auxílio financeiro.

Às comunidades quilombolas, especialmente às lideranças e aos agentes de saúde, pela colaboração na concretização deste trabalho.

Ao Departamento de Genética e Biologia Evolutiva do Instituto de Biociências e seus funcionários da secretaria pela garantia da estrutura para o desenvolvimento desse trabalho. 


\section{Sumário}

$\begin{array}{ll}\text { Resumo } & 13\end{array}$

$\begin{array}{lr}\text { Abstract } & 15\end{array}$

1. Introdução 17

1. 1. Polimorfismos Genéticos e a Genética de Populações 18

1. 2. Estudos sobre a variabilidade humana em escala global 22

1. 2. 1. Projeto da Diversidade do Genoma Humano (HGDP) 23

1. 2. 2. The International HapMap Consortium 24

1. 2. 3. Projeto Genográfico 24

1. 3. Estudos com Polimorfismos Genéticos no Brasil 25

1. 4. O DNA Mitocondrial 28

1. 4. 1. Polimorfismos de DNA mitocondrial 31

1. 4. 2. Propriedades do DNA Mitocondrial 36

1. 5. Diversidade genética do DNA mitocondrial nos brasileiros atuais 38

1. 5. 1. Populações Ameríndias 38

1. 5. 2. Populações Urbanas Predominantemente Brancas 40

1. 5. 3. Populações Afro-descendentes 41

1. 6. Ocupação Humana do Brasil 42

1. 6. 1. O Colonizador Português 43

1. 6. 2. Os Nativos brasileiros 44

1. 6. 3. Os Africanos 45

1. 7. Os Remanescentes de Quilombos

1. 7. 1. Remanescentes de quilombos do Vale do Ribeira - São Paulo

2. Objetivos

3. Material e Métodos

3. 1. Amostras 56

3. 2. Metodologia 58

3. 2. 1. Extração de DNA genômico e quantificação do DNA 58

3. 2. 2. Estudo dos polimorfismos de DNA mitocondrial 58

3. 2. 3. Metodologias de PCR-RFLP e de estudo da deleção de $9 \mathrm{pb}$

3. 2. 4. Metodologia do sequenciamento da região hipervariável (HVS-I) 59

3. 2. 5. Análise Estatística dos Resultados 61

3. 2. 5. 1. Mistura Interétnica 61

3. 2. 5. 2. Redes de Haplótipos (Networks) 62

3. 2. 5. 3. Diversidade Genética 62

3. 2. 5. 4. Diferença Par-a-Par (Pairwise Difference) 63

3. 2. 5. 5. Distância Genética 63

4. Resultados $\quad 65$

4. 1. Frequência dos Haplogrupos Mitocondriais e Mistura Interétnica 66 
4. 2. Redes de Haplótipos (Networks) 76

4. 3. Estimativas de Diversidade Genética 85

4. 3. 1. Diversidade haplotípica e nucleotídica 85

4. 3. 2. Distribuição das diferenças par-a-par 87

4. 4. Distância Genética 93

5. Discussão 96

5. 1. Frequência dos Haplogrupos Mitocondriais e Mistura Interétnica 97

5. 1. 1. Populações Afro-Descendentes do Vale do Ribeira 97

5. 1. 2. População miscigenada da cidade de São Paulo 101

5. 2. Redes de haplótipos $\quad 102$

5. 3. A Origem das sequências HVS-I dos Haplótipos Mitocondriais 103

5. 4. Estimativas de Diversidade Genética $\quad 110$

5. 4. 1. Diversidade haplotípica e nucleotídica 110

5. 4. 2. Diferenças par-a-par (Pairwise Differences) 114

5. 5. Distância Genética $\quad 115$

6. Conclusões 123

7. Referências $\quad 126$

$\begin{array}{lr}\text { Anexo I } & 146\end{array}$ 


\section{Lista de Figuras}

Figura 1 - Mapa do DNA mitocondrial humano.

Figura 2a - Distribuição geográfica mundial dos haplogrupos e inferências sobre o padrão das migrações humana.

Figura 2b - Filogenia simplificada dos haplogrupos de DNA mitocondrial.

Figura 3 - Representação esquemática das principais rotas e períodos do tráfico de escravos entre o continente africano e o território brasileiro.

Figura 4 - Mapa dos estados de São Paulo e Paraná, com área indicando a localização dos remanescentes de quilombos.

Figura 5 - Localização geográfica das comunidades remanescentes de quilombos na região do Vale do Ribeira.

Figura 6a - Casa característica das comunidades de quilombos (quilombo de Nhunguara).

Figura 6b - Balsa utilizada para chegar às comunidades de Pilões e de Maria Rosa.

Figura 7 - Eletroforese em gel de agarose dos produtos da digestão com a enzima de restrição $H p a$ I, indicando os fragmentos em que a digestão não ocorreu (300pb) e os fragmentos em que a digestão ocorreu (150pb).

Figura 8 - Eletroforese em gel de agarose a 3\% dos produtos da amplificação da PCR, indicando fragmentos portadores da deleção (112pb) e fragmentos sem deleção (121pb).

Figura 9 - Resultado do sequenciamento da região hipervariável do DNA mitocondrial (HVS-I) com o primer reverse.

Figura 10 - Rede das linhagens do sub-haplogrupo L1b africano.

Figura 11 - Rede das linhagens do sub-haplogrupo L1c africano.

Figura 12 - Rede das linhagens do haplogrupo L1 africano.

Figura 13 - Rede das linhagens do haplogrupo L2 africano.

Figura 14 - Rede das linhagens do haplogrupo L3 africano.

Figura 15 - Rede das linhagens do haplogrupo A e B amerindio. 
Figura 16 - Rede das linhagens dos haplogrupo C e D ameríndios.

Figura 17 - Rede de todas as linhagens ameríndias.

Figura 18 - Rede de todas as linhagens africanas.

Figura 19 - Distribuição das diferenças par-a-par entre 197 sequências da região hipervariável do DNA mitocondrial de linhagens africanas das doze comunidades remanescentes de quilombos do Vale do Ribeira.

Figura 20 - Distribuição das diferenças par-a-par entre 192 sequências da região hipervariável I do DNA mitocondrial de linhagens ameríndias das doze comunidades remanescentes de quilombos do Vale do Ribeira.

Figura 21 - Distribuição das diferenças par-a-par entre 382 sequências da região hipervariável I do DNA mitocondrial de linhagens das doze comunidades remanescentes de quilombos do Vale do Ribeira reunidas.

Figura 22 - Distribuição das diferenças par-a-par entre 104 sequências da região hipervariável I do DNA mitocondrial de linhagens da amostra da cidade de São Paulo.

Figura 23 - Árvore das relações filogenéticas entre as comunidades remanescentes de quilombos do Vale do Ribeira e uma amostra da cidade de São Paulo, com base na distância Fst entre as linhagens mitocondriais.

Figura 24 - Árvore das relações filogenéticas entre as comunidades remanescentes de quilombos do Vale do Ribeira, uma amostra da cidade de São Paulo e populações de referência, com base na distância $F$ st entre as linhagens mitocondriais.

Figura 25 - Árvore das relações filogenéticas considerando os grandes grupos populacionais com base na distância $F s t$ entre as linhagens mitocondriais. 


\section{Lista de Tabelas}

Tabela I - Populações, número de adultos e o total de habitantes de cada uma das populações estudadas.

Tabela II - Resultados da determinação dos haplogrupos mitocondriais nas 12 comunidades remanescentes de quilombos do Vale do Ribeira.

Tabela III - Resultados da análise molecular do DNA mitocondrial (HVS-I) das 12 comunidades remanescentes de quilombos do Vale do Ribeira.

Tabela IV - Resultados das análises moleculares do DNA mitocondrial, referentes a amostra de indivíduos da cidade de São Paulo.

Tabela V - Diversidades haplotípicas e nucleotídicas nas amostras dos remanescentes de quilombos do Vale do Ribeira e de uma amostra da cidade de São Paulo com base na região hipervariável I do DNA mitocondrial.

Tabela VI - Estimativas de diversidade nucleotídica do DNA mitocondrial em populações indígenas e na fração ameríndia de afro-descendentes do Vale do Ribeira.

Tabela VII - Estimativas de diversidades genéticas, representadas pelas estimativas de diversidade haplotípica (Hd) e média das diferenças nucleotídicas (k), em populações do continente africano e no estoque de linhagens africanas nos afro-descendentes do Vale do Ribeira. 


\section{Resumo}

O Vale do Ribeira é uma área que ocupa cerca de $10 \%$ da região sul do estado de São Paulo e abriga pelo menos 30 remanescentes de quilombos. Dessas, 24 já foram oficialmente reconhecidos ou estão em fase de reconhecimento.

Com a finalidade de contribuir para o conhecimento da estrutura populacional e da história de formação dessas comunidades afro-descendentes, estudamos o DNA mitocondrial de 939 indivíduos adultos de doze populações de quilombos: Abobral Margem Esquerda (100), Abobral Margem Direita (41), Galvão (59), São Pedro (65), Pedro Cubas (100), Pilões (49), Maria Rosa (19), André Lópes (110), Nhunguara (123), Sapatu (95), Ivaporunduva (133), Poça (51), além de uma amostra de 104 indivíduos da cidade de São Paulo. As estratégias empregadas para a determinação dos haplogrupos de DNA mitocondrial se basearam em PCR-RFLP (sítio 3592 com a enzima Hpa I), estudo da deleção de $9 \mathrm{pb}$ (entre os genes da COII e RNAt ${ }^{\text {Lys }}$ ) e sequenciamento da região hipervariável I do DNA mitocondrial (HVS-I).

Nas doze populações de quilombos, importante contribuição ameríndia (com 49,3\% de linhagens) e africana (49,2\% das linhagens) foram detectadas e poucas linhagens européias foram observadas. Resultados de estudos sobre a origem dos cromossomo Y, realizados nas mesmas comunidades do Vale do Ribeira por nossa equipe contrastam com as análises de DNA mitocondrial, pois indicaram reduzida contribuição ameríndia. Essa assimetria sugere pouca importância do homem indígena e muita importância da mulher indígena na origem dessas comunidades. Os resultados de sequenciamento da HVS-I indicaram a provável origem na região centro-oeste africana (Bantos) para as linhagens africanas, com destaque para o atual território de Angola. Uma possível contribuiçãodas populações indígenas Guarani e Kaigang na origem das linhagens ameríndias foi detectada.

Foi possível identificar em quase todas as populações afro-descendentes haplótipos predominantes, tanto de origem africana como ameríndia, candidatos a fundadores, com exceção feita a Maria Rosa, André Lópes, Nhunguara e Poça. Galvão foi a comunidade de quilombo que evidenciou maior efeito de fundador e, consequentemente, onde se observou o menor índice de diversidade haplotípica.

$\mathrm{Na}$ análise dos dendrogramas, os remanescentes de quilombos de Galvão, São Pedro, Sapatu e Ivaporunduva mostram-se mais próximos das populações ameríndias do que das 
demais populações da literatura. As demais comunidades remanescentes de quilombos (André Lópes, Poça, Pedro Cubas, Abobral, Nhunguara, Pilões e Maria Rosa) estão geneticamente mais próximas de populações da etnia Banto. A comunidade da Poça se manteve próxima a São Paulo e separada das demais comunidades quilombolas, provavelmente devido à maior presença de material genético europeu nessa comunidade. As proximidades genéticas observadas entre os grupos de populações Galvão e São Pedro; Abobral Margem Esquerda e Margem Direita; São Pedro, Galvão, Sapatu e Ivapotunduva e, finalmente, entre Nhunguara e André Lopes, é confirmada pelos registros históricos, que atestam para proximidade genealógica e geográfica desses grupos. Pilões e Maria Rosa não se apresentaram tão próximas entre si, como esperado, provavelmente devido à redução do tamanho populacional. Finalmente, como esperado pelos registros históricos, os demais afro-descendentes do Brasil e populações africanas da etnia banto formaram um clado, assim como os brasileiros brancos e as populações de origem portuguesa que também formaram um clado.

Os nossos resultados apontam para uma formação genética e histórica muito rica e diversa nos remanescentes de quilombos. Especialmente relevante foi a constatação de importante contribuição genética indígena preservada nos quilombos. Essas populações, paradoxalmente, podem fornecer um excelente material para investigar a diversidade genética dos ameríndios. Este fato é é importante, se considerarmos o processo contínuo de depopulação indígena provocada pela entrada de grupos europeus no continente americano. 


\section{Abstract}

At least 30 quilombo remnants are supposed to exist in the Vale do Ribeira region, located in the southern part of São Paulo State. Twenty-four of those African-derived have already been identified and officially recognized as quilombo remnants.

In order to shed light on the structure and history of the foundation of these quilombo remnants we investigated the mitochondrial DNA of 939 individuals from twelve populations: Abobral Left Margin (100), Abobral Right Margin (41), Galvão (59), São Pedro (65), Pedro Cubas (100), Pilões (49), Maria Rosa (19), André Lópes (110), Nhunguara (123), Sapatu (95), Ivaporunduva (133), Poça (51). In addition, we investigated 104 individuals sampled from the city of São Paulo. The mitochondrial DNA haplogroups were identified by PCR-RFLP (site 3592 with the Hpa I enzyme), a 9pb deletion (between COII e RNAt ${ }^{\text {Lys }}$ genes) and sequencing of the first mitochondrial DNA hipervariable region (HVS-I).

The twelve African-derived populations investigated showed high frequencies of Amerindian (49,3\%) and African (49,2\%) lineages and a small European contribution $(1,5 \%)$. Studies based on Y chromosome haplotypes carried out with the same quilombo populations in our laboratory presented contrasting results with the analyses of mtDNA and showed reduced amerindian contribution. This asymmetry suggests reduced genetic contribution of Amerindian men and an important role of Amerindian women during the foundation process of these populations. The sequencing data indicated a probable geographic origin in Central and Western Africa (Bantu) for the African lineages, especially in the current territory of Angola. A possible Guarani and Kaigang origin for the amerindian lineages was indicated.

It was possible to identified in almost all the afro-derived populations, frequent haplotypes considered as candidates to founders, some African and some Amerindian. Exceptions to this rule occurred in Maria Rosa, André Lopes, Nhunguara e Poça populations. Galvão showed the lowest genetic diversity, indicating that this population was the most influenced by founder effect.

In the neighbor-joining tree, built with haplotypic frequencies found in the quilombos, São Paulo and other previously reported populations, the quilombos of Galvão, São Pedro, Sapatu and Ivaporunduva were closer to the Amerindian populations. The remaining 
populations (André Lopes, Poça, Pedro Cubas, Abobral Left Margin, Abobral Right Margin, Nhunguara, Pilões and Maria Rosa) were closer to African Bantu populations. The genetic similarities observed between the population groups of Galvão and São Pedro, Abobral Left Margin and Abobral Right Margin; Nhunguara and André Lopes, and São Pedro, Galvão, Sapatu and Ivaporunduva, were confirmed by historical records that support their geographic and genealogical proximity. Pilões and Maria Rosa, also geographically close, did not cluster together as expected, probably due to a recent population bottleneck. Poça clustered with São Paulo, but kept distant from the remaining quilombo remnants, probably due to the highest relative European ancestral contribution. As expected based on historical records, other Brazilian African-derived populations and African Bantu populations grouped. The same was observed with white Brazilian and Portuguese populations.

Our results indicated a diverse genetic background in the foundation of the quilombo populations. Interestingly, these studies have revealed a high matrilineal genetic contribution of Amerindians. The quilombo remnant populations, paradoxically, seem to be an excellent source of material to investigate the genetic diversity of Amerindian populations. This is of great relevance, taking into account the depopulation of Brazilian native populations which happened after the beginning of the occupation process by European colonizers. 


\section{1 - INTRODUÇÃO}




\section{1 - Introdução}

\section{1 - Polimorfismos Genéticos e a Genética de Populações}

As metodologias históricas, sociológicas e antropológicas eram e ainda são as tradicionais ferramentas nos estudos e da origem do povo brasileiro. Dentro deste contexto, podemos destacar as obras de Paulo Prado em Retrato do Brasil de 1927, de Gilberto Freyre em Casa Grande e Senzala de 1933, de Sérgio Buarque de Holanda em Raízes do Brasil de 1936 e de Darcy Ribeiro em várias obras, como, por exemplo, em O Povo Brasileiro, de 1995, como trabalhos marcantes sobre as origens do povo brasileiro.

Neste esforço multidisciplinar que é reconstruir aspectos da história da formação e miscigenação da população brasileira, a genética molecular e a genética de populações constituem as mais novas ferramentas na compreensão do processo que gerou o brasileiro atual. Dentro deste novo panorama, a filogeografia, ramo da ciência que estuda os processos que governam a distribuição geográfica de linhagens genealógicas dentro das espécies, com ênfase em fatores históricos, ganha um papel importante, integrando conhecimentos da genética molecular, genética de populações, demografia e geografia histórica.

Duas estratégias de estudo são empregadas na genética molecular para a análise da história passada dos humanos: o estudo genético de populações atuais, que permitem inferências sobre a sua história, e o de populações do passado, por meio de estudo genético de ossadas e múmias. Esta segunda estratégia também pode ser chamada de arqueologia molecular (Renfrew e Boyle, 2000).

Por muito tempo predominaram os polimorfismos protéicos, hoje chamados de polimorfismos clássicos, como objeto dos estudos sobre a variabilidade genética humana. Os mais difundidos foram os estudos sobre polimorfismos de grupos sanguíneos, de proteínas do complexo de histocompatibilidade (HLA), de imunoglobulinas e de outras proteínas plasmáticas ou presentes nas hemácias (Cavalli-Sforza e col, 1996; CavalliSforza, 1998; revisão em Cavalli-Sforza e Feldman, 2003).

Os antígenos que caracterizam os diferentes grupos sanguíneos se encontram na superfície das hemácias e podem ser identificados por meio de técnicas imunológicas. Os 
grupos sanguíneos mais estudados são aqueles de importância clínica, como ABO e Rh, mas muitos outros foram estudados.

As proteínas do HLA também se encontram na superfície de certas células, os linfócitos. O sistema antígeno leucocitário humano, ou HLA (do inglês: Human leukocyte antigen), é o nome do complexo principal de histocompatibilidade (MHC) humano. Essas proteínas participam de processos que culminam com a formação dos anticorpos e seu estudo é importante em transplantes de órgãos. O grau de polimorfismo nos genes dessa super família gênica é muito elevado (Cavalli-Sforza e col, 1996; Cavalli-Sforza, 1998; revisão em Cavalli-Sforza e Feldman, 2003). As proteínas da família das imunoglobulinas, os anticorpos, são também muito polimórficas e podem ser estudadas quanto a variações.

Os estudos com marcadores clássicos predominaram entre os anos de 1950 a 1980, aproximadamente. Eles mostram apenas uma pequena parcela da variação genética existente, isto é, apenas aquela que resulta em modificações do produto gênico. Contudo, as análises com polimorfismos protéicos são ainda muito úteis em estudos evolutivos de longo prazo, uma vez que as variações protéicas são evolutivamente mais conservadas que variações de sequências de DNA.

Com o desenvolvimento de métodos investigativos de sequências de DNA, a base molecular desses polimorfismos pode ser diretamente observada. As inferências evolutivas puderam a partir de então ser realizadas não somente pela análise de frequências alélicas, mas também pela comparação molecular entre os diferentes alelos, ou seja, de suas sequências nucleotídicas. Além disso, as regiões não codificadoras de polipeptídeos passaram também a ser alvo de estudo. Os estudos genético-populacionais tornaram-se especialmente mais atraentes e factíveis com o emprego dos marcadores polimórficos de DNA, mais numerosos e, em geral, com maior número de variações do que os polimorfismos protéicos. Ainda acrescenta-se a vantagem de terem sua análise menos trabalhosa e cada vez mais veloz em virtude da automação dos métodos de análise. Diversos marcadores polimórficos de DNA se encontram distribuídos em todo o genoma e são empregados na identificação individual e mapeamento de genes, além dos estudos genético-populacionais.

Polimorfismos de DNA são sequências de nucleotídeos que apresentam duas ou mais diferentes formas. Nos dias de hoje, pode-se aplicar a denominação de "alelos" a qualquer 
variante das sequências de base do DNA. Para se considerar que existe polimorfismo, protéico ou de DNA, o alelo mais raro não deve ter sido mantido na população somente por mutações recorrentes e deve ocorrer com uma frequência maior que 1\% (Kendrew, 1999). É importante destacar que esse limiar de frequência para que se considere um alelo como polimórfico é essencialmente arbitrário e outras propostas para esse valor coexistem na literatura. É problemática não somente a definição de polimorfismo, mas também a confusão que abrange termos como variante ou mesmo mutação, especialmente entre profissionais das área de genética evolutiva e genética médica (Cummings, 2000; Condit e col, 2002).

A seguir apresentaremos uma breve revisão sobre os tipos de polimorfismos genéticos. Esta revisão foi compilada de algumas fontes, como Cavalli-Sforza (1998), Nei e Kumar (2000), "International Human Genome Sequencing Consortium" (2001), Cavalli-Sforza e Feldman (2003), Jobling (2004) e "The International HapMap Consortium” (2007).

Polimorfismos de DNA se originam devido a deleções, substituições e inserções de um ou mais nucleotídeos, devido a variações no número de cópias de sequências repetidas ou também a inserções de elementos genéticos móveis.

Alterações em um único nucleotídeo, causadas por deleções, substituições e inserções, são conhecidas como SNPs (single nucleotide polymorphisms) e podem ser identificados por alterações em sítios de restrição de enzimas, que podem ser criados ou suprimidos (técnica de RFLP), ou pelo sequenciamento de um segmento de DNA. Dados do projeto HapMap registram aproximadamente 3,1 milhões de SNPs mapeados e genotipados em 270 indivíduos de quatro regiões geográficas do planeta (International HapMap Comsortium, 2007).

Variações no número de cópias de sequências repetidas são conhecidas como VNTRs (variable number of tandem repeats). Uma repetição em série (tandem repeat) é uma sequência de DNA que é repetida em série e adjacente num locos cromossômico específico. As repetições em série são encontradas ao longo de todo o genoma humano e o número de unidades repetidas varia entre indivíduos. As vantagens das VNTRs são a existência de grande número de alelos diferentes na população e o fato de serem muito numerosas, consistindo em cerca de 3\% do total do genoma humano. Elas podem ser classificadas de acordo com o tamanho de suas unidades de repetição. As mais abundantes no genoma 
humano são as repetições do tipo microssatélites, com unidades de repetição entre uma a 13 bases. Existem também as repetições do tipo minissatélites, com unidades de repetição que variam de 14 a cerca de 500 bases (International Human Genome Sequencing, 2001). Há outros critérios, no entanto, para a classificação de microssatélites e minissatélites, em função do tamanho da unidade de repetição.

Outro grupo de polimorfismos é aquele relacionado às inserções de elementos retrotransponíveis, divididos em LINEs (long interspersed elements) e SINEs (short interspersed elements). As inserções de sequências Alu, um tipo de SINE, são uma classe de DNA repetitivo encontrada no genoma de mamíferos, composta principalmente por sequências que se originaram como transcritos reversos de moléculas de RNA 7SL. A família de elementos Alu representa a SINE mais frequente, correspondendo a cerca de $14 \%$ do genoma humano. A LINE mais abundante no genoma humano é a L1, correspondendo a cerca de $21 \%$ do genoma humano. As LINEs possuem sequências codificadoras de transcriptase reversa e de endonuclease, sequências reguladoras de transcrição e regiões promotoras. Possuem, portanto, a maquinaria enzimática completa necessária à sua retrotransposição, o que não ocorre com as SINEs. A presença ou a ausência das inserções tanto de Alu quanto de LINEs caracterizam dois alelos: um em que ocorreu a inserção e outro em que ela não ocorreu.

Os diferentes tipos de marcadores polimórficos possuem uma taxa de evolução característica. Essas taxas podem ser classificadas como lentas ou rápidas. Os marcadores com taxas lentas (SNPs e inserções de elementos retrotransponíveis) têm a vantagem de diminuir a probabilidade de mutações recorrentes, mas se limitam a uma menor diversidade de alelos na população. Os marcadores com taxas evolutivas rápidas (VNTRs) contam com a vantagem de serem altamente polimórficos, estando, porém, mais sujeitos às mutações recorrentes. Mutações recorrentes podem levar a interpretações errôneas sobre a relação entre as entidades em estudo, sejam elas espécies ou moléculas.

O segmento exclusivo não recombinante do cromossomo Y e o DNA mitocondrial (DNAmt) possuem particularidades genéticas que os tornam atraentes para o estudo da história humana. Primeiro, eles são herdados de apenas um dos pais: o cromossomo Y é transmitido pelo espermatozóide apenas para descendentes do sexo masculino e o DNA mitocondrial é transmitido por meio do óvulo para filhos e filhas. Em segundo lugar, não 
trocam genes com segmentos genômicos semelhantes, isto é, não sofrem recombinação, sendo transmitidos em bloco às gerações seguintes.

Os polimorfismos encontrados no DNAmt e no segmento exclusivo não recombinante do cromossomo Y são fruto única e exclusivamente de mutações que ocorreram ao acaso ao longo do tempo e são transmitidas às gerações futuras de forma inalterada. As mutações ocorridas ao longo da evolução geram, portanto, as variações que servem como marcadores de linhagens. Estas características permitem estudos sobre as histórias matrilineares e patrilineares, respectivamente, das populações humanas, fornecendo informações complementares.

Contudo, devemos considerar as eventuais perdas de informação quando se estudam populações atuais. Isto ocorre, pois as linhagens de DNAmt e de cromossomo Y podem ser mais facilmente extintas do que outros tipos de sequiências presentes nos autossomos. Isto acarreta que a informação obtida corresponde a uma pequena parcela da contribuição genética total dos antepassados de um indivíduo (Hedges e col, 1992).

\section{2 - Estudos sobre a variabilidade humana em escala global}

Questões amplas como a origem do homem moderno e os grandes trajetos da sua dispersão pelo globo, bem como as grandes migrações intercontinentais que ocorreram ao longo de milhares de anos e que moldaram a atual diversidade de povos foram tratadas em diversos estudos por meio de análises de polimorfismos de DNA (e.g, Schurr e col, 1990; Torroni e col, 1992, 1993; Forster e col, 1996; Underhill e col, 2000; Underhill e col, 2001; Fiedel, 2000; Ingman e Gyllensten, 2001; Fix, 2002; Forster, 2004; Schurr, 2004; Schurr e Sherry, 2004; Ballard e Rand, 2005; Forster e Matsumura, 2005; Mellars, 2006; Underhill e Kivisild, 2007; Derenko e col, 2007; Atkinson e col, 2008).

Como a modernização das técnicas de análise de DNA e com o acúmulo de informações dos estudos genético-populacionais, surgiram nos últimos anos diversas iniciativas em escala global de unificar os esforços dos estudos sobre a variabilidade genética humana. Com esse objetivo, vale a pena citar três importantes e audaciosos projetos para mapear a diversidade genética humana. Questões sobre as origens do homem moderno, os padrões de dispersão das populações humanas, padrões de diversidade genética e possíveis aplicações dessas informações na área biomédica estão entre os objetivos comuns a essas iniciativas. 


\subsection{1 - Projeto da Diversidade do Genoma Humano (HGDP)}

O primeiro projeto de um estudo sistemático da diversidade genética humana com base nas moléculas de DNA teve início nos anos 90. O geneticista Luigi Cavalli-Sforza, do Morrison Institute da Universidade de Stanford, propôs um projeto para construir uma grande coleção de informações genéticas de populações das mais diversas partes do mundo para a realização de estudos comparativos sobre variabilidade humana (http://www.stanford.edu/group/morrinst/hgdp.html). A proposta foi conhecida como HGDP (The Human Genomic Diversity Project). Logo no início do projeto, em 1994, dificuldades éticas e obstáculos políticos atrasaram o andamento das investigações. Um importante obstáculo inicial foi o questionamento de povos indígenas e organizações nãogovernamentais quanto a um possível envolvimento de interesses comerciais no projeto (Cavalli-Sforza, 2005). De 1994 a 1997 os organizadores do HGDP reorganizaram o projeto que foi submetido a análise no NAS-NCR (National Research Council of the National Academy of Sciences) dos EUA, recebendo aprovação no final de 1997. O projeto desde então é supervisonado pelo NIH (National Institute of Health). O principal esforço do HGDP foi organizar uma coleção de linhagens celulares linfoblastóides provenientes de populações de diversas partes do planeta. Esta coleção está sediada no CEPH (Center for the Study of Human Polymorphims) localizado na Fundação Jean Dausset em Paris, França. Este centro também é responsável pela distribuição de amostras de DNA da coleção para laboratórios interessados em pesquisas antropológicas e biomédicas. Atualmente, a coleção consiste em 1064 linhagens celulares provenientes de 52 populações ao redor do globo. Até o momento, 56 laboratórios já realizaram pedidos para ter acesso à coleção.

Em 2002, Rosenberg e col. realizaram o primeiro estudo populacional com enfoque bioantropológico utilizando a coleção do HGDP. Analizando 377 locus de microsatélites distribuídos em todos os autossomos, encontraram resultados que dão ênfase ao isolamento geográfico aliado ao efeito de deriva genética como importante fator determinante da diversidade genética humana.

$\mathrm{Na}$ área biomédica, a coleção também mostrou ser uma ferramenta valiosa. Seu valor está relacionado, além de outras potenciais aplicações, a ser um importante provedor de amostras populacionais para uso como grupos controle. Estudos de associação que buscam 
por variantes gênicas que influenciam a susceptibilidade a diversas doenças genéticas humanas encontram uma dificuldade importante que é a obtenção de grupos controle confiáveis. A coleção se propõe a se tornar uma ferramenta importante para a obtenção de amostras apropriadas para tais estudos (Cavalli-Sforza, 2005).

\subsection{2 - The International HapMap Consortium}

O objetivo do projeto internacional do HapMap é desenvolver um mapa de haplótipos do genoma humano. Tem como objetivo descrever os padrões frequentes da variação da seqüência do DNA humano, pelo método de genotipagem de $S N P$ s. Espera-se que o HapMap seja um importante recurso para que os pesquisadores possam encontrar genes associados às doenças e às respostas às drogas.

Dados da segunda fase do projeto apontam para aproximadamente 3,1 milhões de SNPs mapeados e genotipados em 270 indivíduos de quatro regiões geográficas do planeta (The International HapMap Consortium, 2007). Dados podem ser acessados publicamente no dbSNP (The Single Nucleotide Polymorphism database) hospedado no NCBI (National Center for Biotechnology Information) e acessados em: http://www.ncbi.nlm.nih.gov/projects/SNP/.

\subsection{3 - Projeto Genográfico}

Em 2005, a National Geographic Society e a IBM deram início a um projeto na tentativa de recompor a história das migrações da espécie humana. O Projeto Genográfico (Genographic Project) pretende análisar amostras de DNA, por meio de marcadores mitocondriais, do cromossomo $\mathrm{Y}$ e dos autossomos, de centenas de milhares de pessoas, incluindo representantes de populações nativas e de diversos segmentos da sociedade em geral, para rastrear a história do povoamento da Terra. Liderado por Spencer Wells, PhD, pesquisador-residente da National Geographic, um grupo de cientistas irá coletar amostras, analisar os resultados e elaborar relatórios a respeito das raízes genéticas dos seres humanos contemporâneos. Dez centros de pesquisas estão distribuídos em áreas estratégicas nos cinco continentes, para a coleta de amostras de DNA de comunidades nativas locais. O projeto conta com a aprovação do IRB (Social and Behavioral Sciences Institutional 
Review Board) da University of Pennsylvania Office Regulatory Affairs, desde abril de 2005.

Espera-se que o projeto revele detalhes a respeito da história da migração e que leve a uma nova abordagem das conexões e diferenças que ocorrem entre os indivíduos da espécie humana. O banco de dados público resultante do trabalho abrigará uma das maiores coleções de informações genéticas sobre os humanos.

Os dados preliminares do projeto podem ser acessados publicamente em: http://www.nationalgeographic.com/genographic. O estudo iniciou em 2005 e há a previsão de que vai durar cinco anos. Dados até agora coletados totalizam 78.590 genótipos provenientes de indivíduos de diversas partes do mundo (Behar e col, 2007).

\section{3 - Estudos com Polimorfismos Genéticos no Brasil}

No Brasil, os estudos com marcadores clássicos, realizados predominantemente com populações do nordeste e do sudeste do país, já demonstravam um certo grau miscigenação da população brasileira, cujo padrão variava de acordo com a região analisada (revisão em Salzano, 1997; Callegari-Jacques e Salzano, 1999; Dornelles e col, 1999; Guerreiro e col., 1999; Salzano, 2002). Estudos realizados em comunidades afro-brasileiras nas regiões Norte, Sul e Nordeste do Brasil, revelaram em suas estimativas de mistura interétnica uma maior contribuição de genes de origem africana em relação a contribuição de origem ameríndia e européia (Schneider e col, 1987; Bortolini e col, 1995, 1998; Guerreiro e col, 1999). Estes resultados ratificam a história de formação dessas comunidades, que são de

origem predominantemente africana. Por outro lado, estudos com populações brancas da região Sul do Brasil (Rio Grande do Sul e Santa Catarina) revelaram, como esperado, maior contribuição de genes de origem européia (Dornelles e col, 1999). Em relação às populações indígenas do Brasil, diversos trabalhos realizaram estudos sobre a variabilidade genética por meio de marcadores clássicos (Salzano e Callegari-Jacques, 1988; Salzano e col, 1991; Callegari-Jacques e col, 1994, 1996; Salzano e col, 1997; Bortolini e col, 1997). O achado mais importante desses trabalhos é a tendência geral das estimativas de diversidade genética nos ameríndios serem menores quando comparadas com qualquer outro grupo populacional, miscigenado ou não. O despovoamento provocado pelo colonizador português e os prováveis efeitos de graves gargalos sofridos durante o processo 
de expansão do homem moderno da Ásia para a América, foram as explicações frequentemente levantadas para explicar esses relativos baixos índices de diversidade.

Desde a década de 80, os polimorfismos de DNA (presentes nos autossomos, no cromossomo $\mathrm{Y}$ e no DNA mitocondrial) foram utilizados no Brasil em estudos relacionados à origem e formação da população brasileira e relacionados também à origem do homem no Novo Mundo (e.g, Santos e col, 1993; Pena e col, 1995; Rodriguez-Delfin e col, 1997; Santos e col, 1999; revisão em Salzano, 1997; Bonatto e col, 1997a, 1997b; Bortolini e col, 1997b, 1999, 2002, 2003; Callegari-Jacques e Salzano, 1999; Alves-Silva e col, 2000; Carvalho-Silva e col, 2001; Rodriguez-Delfin e col, 2001; Tarazona-Santos e col, 2001; Tarazona-Santos e Santos, 2002; Battilana e col, 2002; Fagundes e col, 2002; Marrero e col, 2005; Dornelles e col, 2005; Ribeiro-dos-Santos e col, 2002; Feio-dosSantos e col, 2006; Salzano e Callegari-Jacques, 2006; Ribeiro-dos-Santos e col, 2007; Wang e col, 2007; Carvalho e col, 2008; Barbosa e col, 2008; Fagundes e col, 2008a, 2008b).

Dois estudos importantes foram realizados sobre a caracterização de populações brasileiras brancas de grandes centros urbanos, utilizando marcadores de DNA mitocondrial (Alves-Silva e col, 2000) e do cromossomo Y (Carvalho e col, 2001). Os resultados destes estudos indicaram que cerca de 60 a $80 \%$ dos cromossomos $\mathrm{Y}$ dos brasileiros brancos são de origem européia, provavelmente portuguesa. Não foi encontrado nenhum cromossomo $\mathrm{Y}$ de origem ameríndia nessas amostras. Em relação às linhagens de DNA mitocondrial, os resultados são bem diferentes: cerca de $40 \%$ são de origem européia, $30 \%$ de origem africana e 30\% de arigem ameríndia ou asiática. Esse elevado grau de miscigenação em indivíduos considerados brancos é um achado notável. A importância da contribuição negra na população brasileira foi também reforçada pelas estimativas de miscigenação obtidas pela análise de polimorfismos autossômicos (Pena e Bortolini, 2004). Neste trabalho foi estimado que 87\% dos brasileiros (cerca de 146 milhões de pessoas) apresentam mais de $10 \%$ de ancestralidade genômica africana.

O grau elevado de miscigenação da população brasileira ficou também evidente em um estudo realizado por Parra e col, em 2003. Os pesquisadores analisaram 10 marcadores moleculares autossômicos (inserções de Alu e SNPs) e características morfológicas (cor da pele, forma do nariz, lábios e tipo de cabelo) comumente usadas para definição de raças. O 
objetivo do trabalho foi verificar a existência de uma correlação entre cor de pele dos brasileiros e alelos considerados específicos de africanos, ameríndios e portugueses. Nenhuma correlação foi encontrada entre estimativas genéticas de ancestralidade e as características morfológicas comumente utilizadas para definição de raças. Outros trabalhos na mesma linha reforçam conceito de que no Brasil, a cor da pele nem sempre mostra correlação direta com a ancestralidade (Pimenta e col, 2006).

Com o objetivo de avaliar a constituição genética e origem do estoque africano presente no Brasil, diversos estudos analisaram populações afro-brasileiras rurais (remanescentes de quilombos) (eg. Schneider e col, 1987; Guerreiro e col, 1999; Bortolini e col, 1992, 1995, 1998, 1999; Silva Jr. e col, 2006; Ribeiro-dos-Santos e col, 2002, 2007; Carvalho e col, 2008) e urbanas (eg. Bortolini e col, 1995, 1997a, 1997b, 1999; Silva Jr. e col, 2006; Hünemeier e col, 2007; Gonçalves e col, 2008) além de populações urbanas miscigenadas (eg. Feio-dos-Santos e col, 2006; Barbosa e col, 2008).

Um exemplo recente de estudo com afro-brasileiros do estado de São Paulo foi o de Gonçalves e col. (2008). Foi detectado que $48 \%$ das linhagens de cromossomo Y e $85 \%$ das linhagens mitocondriais eram originárias da África subsaariana. Apenas 1,7\% das patrilinhagens possuíam origem ameríndia. A presença de linhagens de cromossomo Y européias foi significativa, provavelmente causada pelo fenômeno de cruzamento direcional entre homens europeus e mulheres africanas. Assimetrias sexuais similares foram também descritas em populações afro-americanas (e.g. revisão em Lind e col, 2007; Mendizabal e col, 2008).

Vale a pena também destacar alguns trabalhos que procuraram obter estimativas da origem geográfica da contribuição africana na população brasileira por meio do estudo de pacientes afetados por anemia falciforme (Zago e col, 1992; Gonçalves e col, 1994; Figueiredo e col, 1994; Wagner e col, 1996; Pante-de-Souza e col, 1998; Gonçalves e col, 2003; revisão em Cardoso e Guerreiro, 2006). Sabe-se que existem cinco haplótipos de RFLPs ligados à mutação que causa a anemia falciforme, nomeados de acordo com sua área de ocorrência. Desses, quatro são africanos: haplótipo Banto, presente nos afetados da região Sul e central da África (inclui Congo, Angola e África do Sul) e regiões da África oriental (que inclui Moçambique); haplótipo Senegal, predominante na África Ocidental (Senegal e Gâmbia); haplótipo Benin, presente na região de Benin, Nigéria, e haplótipo 
Camarões, presente na região de Camarões. O quinto haplótipo, chamado de Indo-árabe, ocorre na região sul da Ásia. O quadro geral obtido nesses estudos indicou que cerca de $69 \%$ dos indivíduos afetados têm o haplótipo Banto, 30\% o haplótipo Benin e $1 \%$ o haplótipo Senegal. O haplótipo Benin foi o mais frequente somente em Salvador (45\%), o que comprova o grande fluxo de escravos entre essas duas regiões. Em um trabalho do nosso grupo realizado com afro-descendentes dos remanescentes de quilombos do Vale do Ribeira, região Sudeste do Brasil (Auricchio e col, 2007), ao se analisarem 86 indivíduos com traço falcêmico de 11 comunidades, o haplótipo Banto foi também o mais frequente $(81,4 \%)$, seguido dos haplótipos Benin e Senegal $(8,1 \%)$ e finalmente do haplótipo Camarões (2,3\%). Esta proporção corrobora os relatos históricos de que a maior parte dos escravos africanos teriam origem nos Bantos, grupo étnico que habita a região central da África (Congo, Angola) e regiões da África oriental (Moçambique).

Em relação aos estudos realizados em populações ameríndias brasileiras destacam-se aqueles realizados com a análise de polimorfismos mitocondriais e de cromossomo Y (e.g, Santos e col, 1996; Bortolini e col, 1997; Bonatto e col, 1997a, 1997b; Bortolini e col, 2002; Marrero e col, 2007; Fagundes e col, 2008a, 2008b). Reforçando os achados obtidos com marcadores clássicos, esses trabalhos com ameríndios também indicaram baixa diversidade genética com elevada diferenciação interpopulacional e, em alguns casos, presença de material genético não indígena devido a fluxo gênico com europeus e africanos.

\section{4 - O DNA Mitocondrial}

A mitocôndria é a organela produtora de energia nas células eucarióticas. Uma característica peculiar da mitocôndria é a presença de material genético próprio circular de dupla-hélice, o chamado DNA mitocondrial (DNAmt). O DNAmt é um material de fácil manuseio em laboratório pois se apresenta já naturalmente muito amplificado. Isto se deve ao fato de que cada célula possui muitas mitocôndrias. O número de mitocôndrias por célula varia significativamente de acordo com o tipo de célula e função biológica que exerce, variando de algumas centenas a alguns milhares destas organelas por célula (revisão em Scheffler, 2001). Além disso, cada mitocôndria apresenta várias cópias de seu próprio 
genoma. Essas características resultam na obtenção de uma quantidade razoável de DNA em uma amostra pequena de tecido coletado.

Nos últimos 30 anos tem sido consolidada a teoria endossímbiótica para a origem da organela mitocondrial. Segundo essa teoria, os ancestrais da organela mitocondrial eram organismos procarióticos, que passaram a viver dentro dos ancestrais das células eucarióticas modernas. Após a consolidação de uma relação de simbiose entre a célula procariótica e a célula hospedeira, o ancestral mitocondrial (endossimbionte) perdeu genes e teve início um processo de transferência desses genes para o núcleo da célula eucariótica ancestral (revisão em Scheffer, 2001). Essas transferências são provavelmente responsáveis pelas variações no tamanho e capacidade codificante nos diferentes DNAs mitocondriais em diversas espécies de eucariotos.

$\mathrm{Na}$ maior parte dos genomas mitocondriais há um pequeno número de genes que codificam constituintes dos complexo da cadeia de transporte de elétrons e de um complexo da ATP sintase. Usualmente, em mamíferos e em grande parte dos metazoários, encontramse 13 proteínas, integrantes desses complexos, codificadas pelo DNAmt. Além disso, encontram-se também codificados 2 RNAs ribossômicos e um conjunto de RNAs transportadores suficientes para a tradução dos RNAs mensageiros mitocondriais. Na grande maioria dos metazoários, o DNAmt apresenta pequenas dimensões, de aproximadamente $16,5 \mathrm{~Kb}$. Em outros organismos, como em algumas plantas, o tamanho pode atingir aproximadamente 350kb (revisão em Scheffer, 2001).

O DNA mitocondrial humano foi sequenciado totalmente em 1981 (Anderson e col, 1981). Ele possui um total de dezesseis mil quinhentos e sessenta e nove nucleotídeos, sendo a maior parte presente dentro de genes (Figura 1). As duas fitas do DNAmt têm diferenças significativas em relação às suas composições: a fita ou cadeia $\mathrm{H}$ (heavy) é rica em guaninas e a cadeia L (light), em citosinas. Uma extensão de aproximadamente mil e duzentos nucleotídeos constitui uma região não codificadora de RNAs ou peptídeos, nomeada como Região Controle ou D-loop. A denominação região controle se refere ao fato dessa região conter os promotores para a transcrição e as origens para a replicação. O termo D-loop está relacionado aos estágios iniciais da replicação onde a recém-sintetizada cadeia de nucleotídeos formada a partir das cadeias parentais se dispõe num formato de alça ou loop. Três segmentos do DNAmt localizados na região controle são altamente 
polimórficos na população humana. Essas regiões são conhecidas como regiões hipervariáveis 1, 2 e 3 (HVS-1, HVS-2 e HVS-3). A região hiperveriável 1 (HVS-1) compreende as posições nucleotídicas de 16024 a 16325, a região hiperveriável 2 (HVS-2) se estende da posição 73 até a 340 e o terceiro segmento hipervariável, chamado HVS-3, está localizado entre as posições 438 e 574 (Lutz e col, 1997). Este terceiro segmento, no entanto, é menos polimórfico que HVS-1 e HVS-2. Estudos bioantropológicos tradicionalmente investigam a região HVS-1. Recentemente, diversos trabalhos têm identificado haplogrupos correlacionando polimorfismos de HVS-1/HVS-2 com variações no restante do DNA mitocondrial (e.g, Crespillo e col, 2000; Thomas e Coble, 2001; Maruyama e col, 2003; Zupanic e col, 2004; Zhang e col, 2005; Umetsu e Yuasa, 2005; Coble e col, 2006; Jin e col, 2006; Lee e col, 2006; Pellekaan e col, 2006; Hedman e col, 2007; Mabuchi e col, 2007; Morovvati e col, 2007; Gonder e col, 2007; Tetzlaff e col, 2007; Wong e col, 2007; Derenko e col, 2007; Barbosa e col, 2008; Chen e col, 2008; Achilli e col, 2008). A região HVS-3 é investigada apenas em alguns casos, quando uma discriminação adicional torna-se necessária tanto em estudos genético-populacionais como forenses.

O termo hipervariável está relacionado com a alta taxa de mutação dessas regiões, cerca de dez vezes maior que a taxa de mutação do DNA nuclear. Essa elevada taxa de mutação tem sido atribuída a três fatores que explicam não só a elevada taxa de mutação das regiões hipervariáveis como de todo o genoma mitocondrial em relação ao DNA nuclear: o fato da mitocôndria ser geradora de espécies reativas de oxigênio, proporcionando um ambiente favorável a mutações no DNA; a ausência de histonas, que exercem um papel protetor no DNA nuclear e o fato do sistema de replicação do DNA mitocondrial possuir baixa atividade de reparo quando comparado ao nuclear (revisão em Wallace, 2007; revisão em Druzhyna e col, 2008).

As regiões codificadoras contêm os genes para vários RNAs e proteínas e representam mais de $90 \%$ do DNA mitocondrial. Possuem uma taxa mutacional cerca de cinco vezes maior que a do DNA nuclear (Anderson e col, 1981) (Figura 1). 


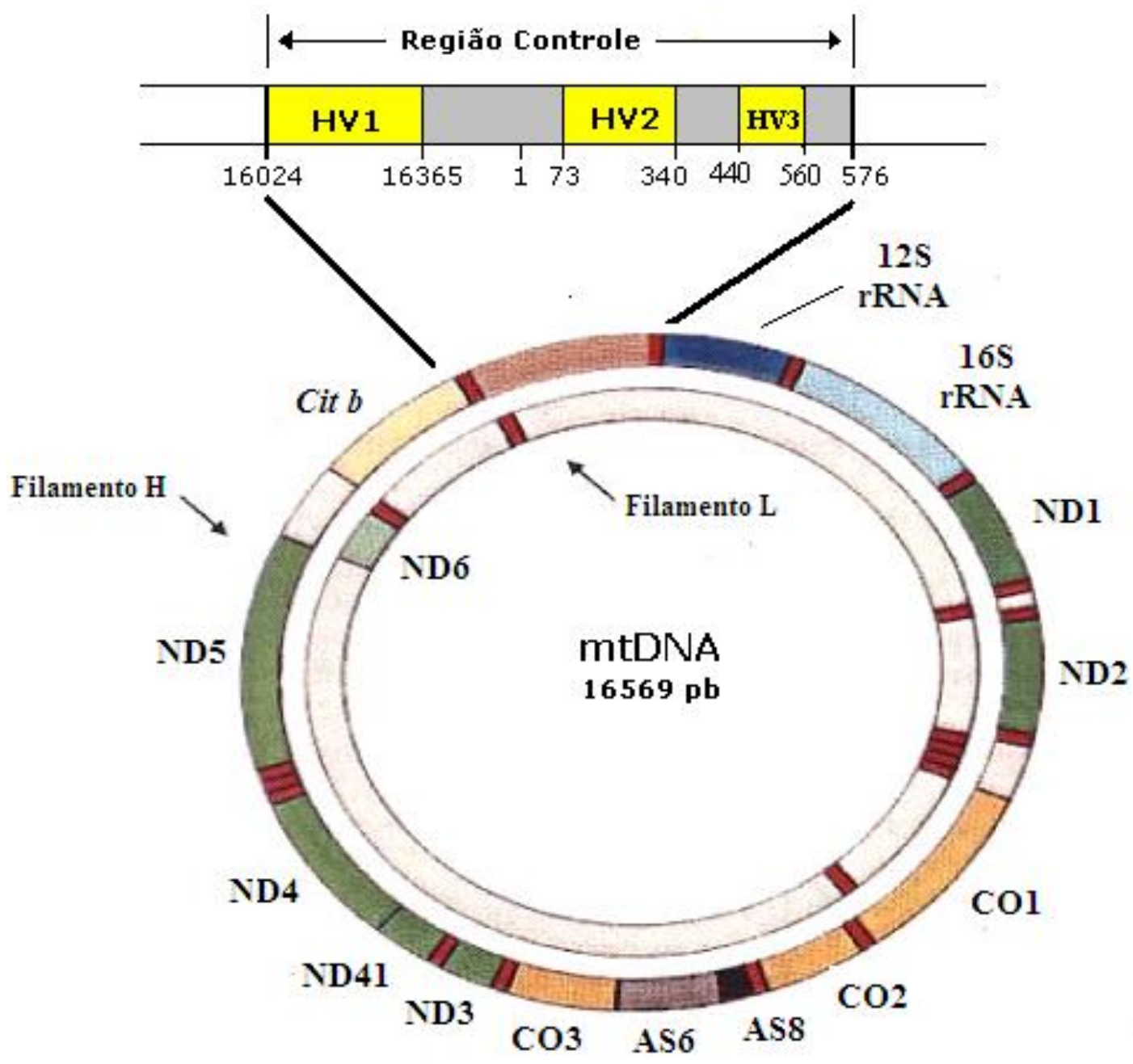

Figura 1 - Mapa do DNA mitocondrial humano com destaque para a região controle nãocodificante. A figura mostra a localização das regiões hiperveriáveis 1 (HV1), 2 (HV2) e 3 (HV3); O sistema de numeração segue o da sequiência de referência padrão (Anderson e col. 1981). Os genes ND indicados na figura (ND1, ND2, ND3, ND4l, ND4, ND5 e ND6) codificam as subunidades do complexo desidrogenase ou complexo I. Os genes AS6 e AS8 codificam as subunidades para o complexo da ATP sintase ou complexo V. Os genes $\mathrm{CO}(\mathrm{CO} 1, \mathrm{CO} 2$ e $\mathrm{CO} 3)$ codificam as subunidades para o complexo citocromo c oxidase ou complexo IV. O gene Cit $b$ codifica uma subunidade do complexo ubiquinol; citocromo c oxiredutase ou complexo III. Os genes $12 \mathrm{~S}$ rRNA e $16 \mathrm{~S}$ rRNA codificam os RNAs ribossômicos. Os genes que codificam os RNA transportadores são os curtos segmentos representados em vermelho. $\mathrm{O}$ filamento $\mathrm{H}$ corresponde à cadeia pesada e o filamento L à cadeia leve do DNA mitocondrial. (Adaptado de www.mitomap.org).

\subsection{1 - Polimorfismos de DNA mitocondrial}

As sequências nucleotídicas do genoma mitocondrial podem apresentar pequenas variações entre indivíduos, que geralmente compreendem mutações não-deletérias do tipo SNPs (single nucleotide polimorphisms). 
Devido à herança estritamente materna e a sua elevada taxa de mutação, DNAs mitocondriais humanos têm sequencialmente acumulado mutações ao longo do tempo, provocando constante irradiação de matrilinhagens desde o ancestral comum africano que existiu aproximadamente entre 150.000 e 200.000 anos atrás (Johnson e col, 1983; Cann e col, 1987; Merriwether e col, 1991; Ingman e col, 2000; Wallace e col, 2000; Mishmar e col, 2003). Como resultado, a história das variantes mitocondriais pode ser reconstruída filogeneticamente a partir de sua origem comum (Ruiz-Pesini e col, 2007).

A medida que as relações filogenéticas passaram a ser elucidadas por meio de estudos de populações nativas oriundas de diferentes regiões do planeta, observou-se que os ramos dessa árvore, isto é, as diferentes linhagens mitocondriais, apresentavam forte correlação com a origem geográfica. Essas correlações foram inicialmente observadas por causa da constatação de que cada grupo populacional apresentava polimorfismos de sítios de restrição continente-específicos (Denaro e col, 1981).

Estudos subsequentes mostraram que todas as variantes mitocondriais podiam ser agrupadas em uma única filogenia e que as variantes mais polimórficas, situadas na raiz dessa filogenia, estavam presentes nas linhagens mitocondriais africanas (Cann e col, 1987; Merriwether e col, 1991).

Os conjuntos de variações de sequência encontradas em uma determinada molécula de DNA mitocondrial foram denominados de haplótipos mitocondriais. Um grupo de haplótipos relacionados, formando um clado filogenético definido, é denominado de haplogrupo (Ingman e col, 2000; Wallace e col, 2000; Mishmar e col, 2003; revisão em Wallace, 2007).

Ambas as regiões, controle e codificadora, são estudadas na detecção dos polimorfismos e identificação de haplótipos e haplogrupos. A região controle tem frequentemente seus nucleotídeos sequenciados e comparados. A região codificadora é analisada buscando-se SNPs em posições específicas. Essa busca é frequentemente realizada com o auxílio de enzimas de restrição.

As linhagens mitocondriais mais diversificadas e portanto mais antigas são as africanas, que são classificadas em quatro grandes haplogrupos: L0 (mais antigo), L1, L2 e L3 (linhagem mais recente). Os haplogrupos L0, L1 e L2 representam aproximadamente 76\% de todas as linhagens subsaarianas e são definidos pela presença de um sítio de restrição 
para a enzima $H p a \mathrm{I}$ na posição 3592. Estes três haplogrupos são também usualmente agrupados no chamado Macro-Haplogrupo L. No nordeste do continente africano, duas linhagens mitocondriais denominadas $\mathrm{M}$ e $\mathrm{N}$ divergiram a partir do haplogrupo L3, aproximadamente há 65.000 anos atrás. Estes dois haplogrupos foram os únicos a deixar o continente africano em direção à Eurásia. $\mathrm{Na}$ Europa, o haplogrupo $\mathrm{N}$ deu origem ao haplogrupo $\mathrm{H}$, que atualmente compreende $45 \%$ de todas as linhagens mitocondriais européias, aos haplogrupos T, U, V, W, além dos haplogrupos I, J e K. Essa irradiação das linhagens européias ocorreu aproximadamente entre 40.000 a 50.000 anos atrás. Na Ásia, as linhagens $\mathrm{M}$ e $\mathrm{N}$ deram origem a diversos haplogrupos. Entre os principais estão os haplogrupos A, B, C, D, F, G, Y e Z (Wallace e col, 1999; Mishmar e col, 2003). Durante a migração humana para a região da Sibéria, apenas os haplogrupos A, C, D e G tornaram-se prevalentes. Os haplogupos A, C e D, que representam $58 \%$ das linhagens mitocondriais siberianas, foram os que incialmente atravessaram o estreito de Bering em direção às Américas. Evidências apontam que o haplogrupo B tenha atingido o continente americano em épocas relativamente mais recentes através de uma rota alternativa contornando a Sibéria. Esta hipótese para o padrão de migração do haplogrupo B se deve ao fato de que este haplogrupo é o único encontrado em nativos americanos que está ausente em populações do norte da Sibéria, é extremamente raro no Norte do continente americano e a diversidade de sequência desse haplogrupo é mais baixa em relação aos haplogrupos $\mathrm{A}, \mathrm{C}$ e D (revisão em Mishmar e col, 2003; revisão em Wallace, 2005). Finalmente um quinto haplogrupo foi identificado nas Américas, o haplogrupo X. Este haplogrupo é encontrado em baixas frequências no Norte da África, nas regiões oeste e central da Ásia, na Europa e no extremo norte do continente americano. No entanto, está ausente na Sibéria e leste da Ásia (Reidla e col, 2003). Dúvidas ainda persistem sobre a origem desse haplogrupo no Velho Mundo e razões de sua aparente presença no Novo Mundo limitada ao extremo norte da América do Norte (Dornelles e col, 2005). Um resumo da história dos principais haplogrupos mitocondriais está apresentado nas Figuras 2a e 2 b. 
Todas as evidências apontam que o continente americano foi o último a ser colonizado pelo homem moderno. Dados moleculares provenientes provenientes de estudos com DNAmt têm sido empregados na tentativa de desvendar os padrões, as rotas e o momento da chegada e dispersão do homem moderno no Novo Mundo (e.g, Torroni e col, 1993; Ward e col, 1993; Szathmary, 1993; Baillet e col, 1994; Torroni e col, 1994; Cann, 1994; Torroni e Wallace, 1995; Bianchi e col, 1995; Forster e col, 1996; Bonatto e Salzano, 1997a,b; Schurr e Sherry, 2004; Tamm e col, 2007; Wang e col, 2007; Kitchen e col, 2008; Fagundes e col, 2008a, 2008b).

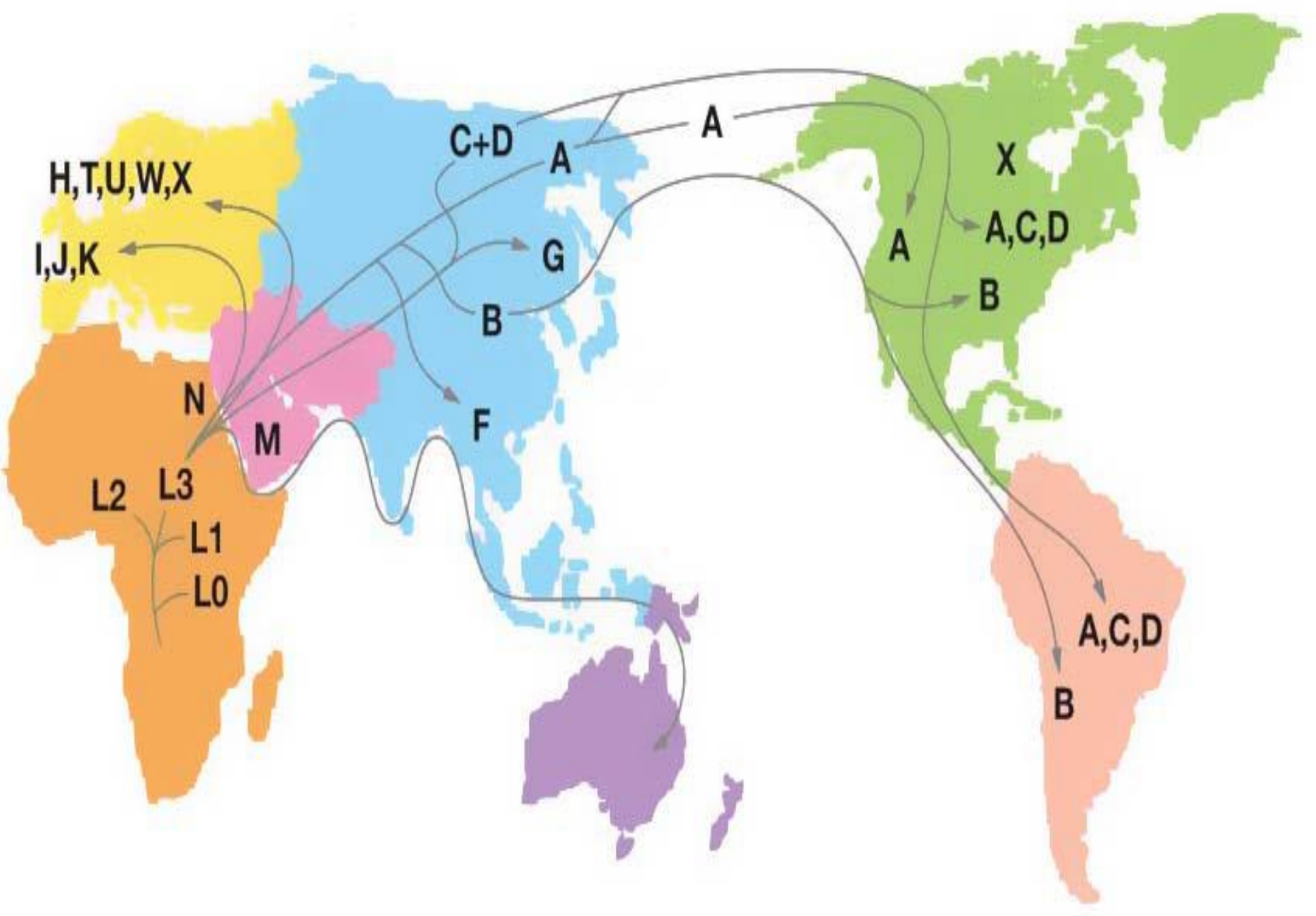

Figura 2a - Distribuição geográfica mundial dos haplogrupos e inferências sobre o padrão das migrações humanas. (Adaptado de http://www.mitomap.org). 


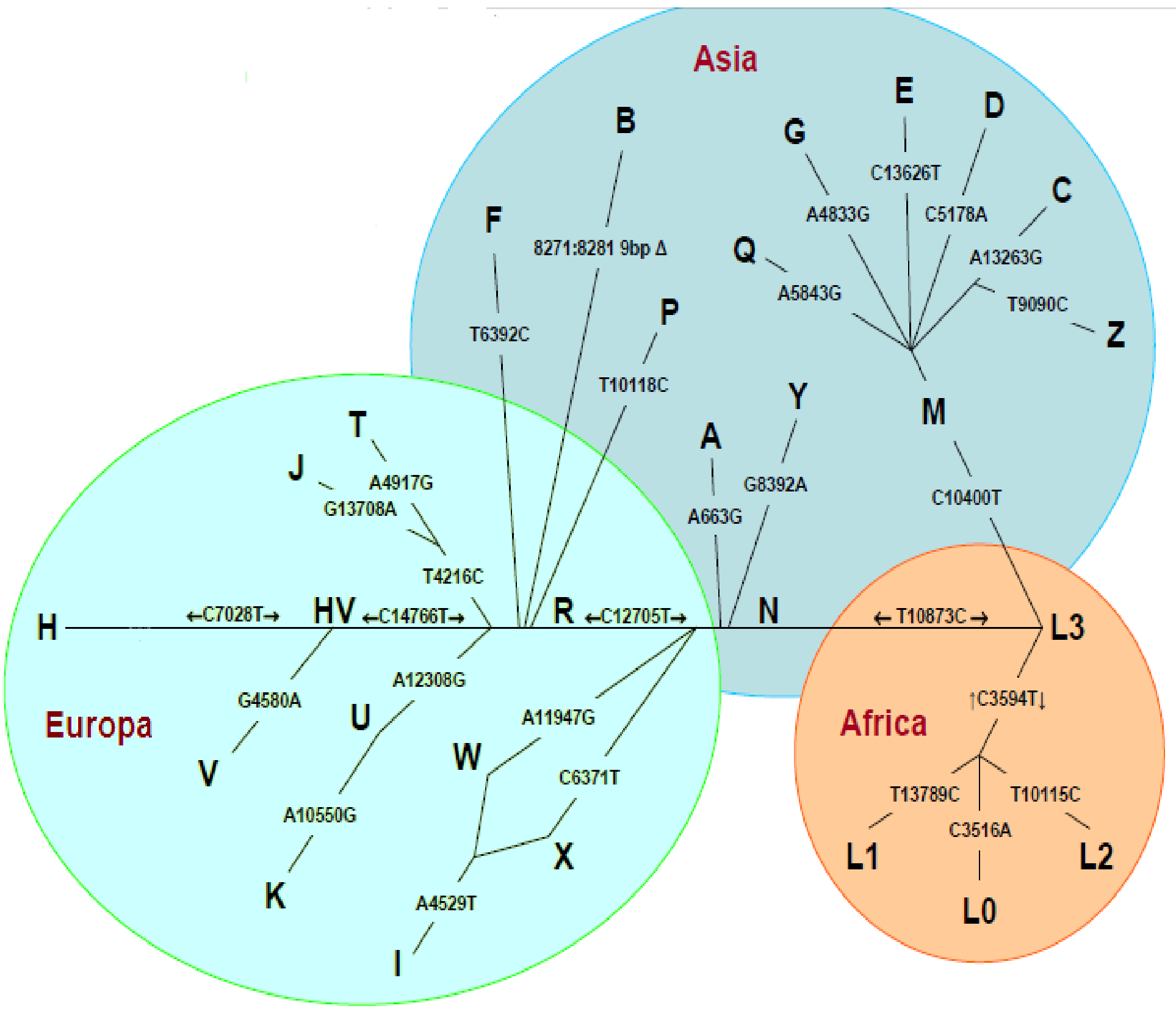

Figura 2b - Filogenia simplificada dos haplogrupos de DNA mitocondrial. As mutações, características de cada haplogrupo, são mostradas nos ramos da filogenia. Os círculos coloridos agrupam os haplogrupos de acordo com sua origem geográfica. (Adaptado de http://www.mitomap.org). 


\subsection{2 - Propriedades do DNA Mitocondrial}

Diversos trabalhos recentemente levantaram dúvidas em relação à validade de algumas propriedades atribuídas à molécula de DNAmt, em especial no que se refere à ausência de recombinação, transmissão exclusivamente materna e sua utilização como um marcador molecular evolutivamente neutro.

A herança estritamente materna foi colocada em questão em 2003 por Bromham e col, por causa de um caso de herança paterna descrito em 2002 por Schuartz e Vissing. Neste trabalho, os pesquisadores identificaram um indivíduo que apresentava predomínio de mitocôndrias paternas em seu tecido muscular. Além de miopatia grave, o indivíduo em questão sofria de intolerância ao exercício, porque o DNAmt de origem paterna tinha uma deleção de $2 \mathrm{pb}$ no gene $N D 2$. Outros casos de transmissão paterna não foram descritos posteriormente em humanos. Diversos estudos subsequentes falharam na identificação da presença de DNAmt paterno, mesmo em indivíduos com miopatias sabidamente de origem mitocondrial (Filosto e col, 2003; Taylor e col, 2003; revisão em Pakendorf e Stoneking, 2005). Sabe-se que as mitocôndrias espermáticas são seletivamente destruídas no oócito (Manfredi e col, 1997; Shitara e col, 1998) e que a mitocôndria paterna é marcada por ubiquitinação para que essa destruição ocorra (Sutovsky e col, 1999; Sutovsky e col, 2000). Atualmente é consenso entre os pesquisadores que os casos de transmissão paterna detectados representam na verdade falhas do mecanismo normal de reconhecimento e destruição da mitocôndria paterna. Desta forma, a transmissão exclusivamente materna da molécula mitocondrial permanece válida como paradigma nos estudos genéticopopulacionais (Schuartz e Vissing, 2003), dada a raridade da transmissão paterna.

A ausência de recombinação da molécula mitocondrial foi também questionada entre os anos de 1999 e 2000 por quatro trabalhos que alegavam apresentar evidências de recombinação mitocondrial (Awadalla e col, 1999; Eyre-Walker e col, 1999; Hagelberg e col, 1999; Kivisild e Villems, 2000). Diversos autores reanalizaram os dados de recombinação inicialmente apresentados e constataram erros de manipulação de dados e estratégias de análise duvisosas, o que teria levado a conclusões errôneas sobre a presença de recombinação (Actander, 1999; Macaulay e col, 1999; Merriwether e Kaestle, 1999; Parsons e Irwin, 2000; Elson e col, 2001; Kvist e col, 2003). No único caso descrito de transmissão mitocondrial paterna em humanos (Schwartz e Vissing, 2002), a recombinação 
entre o DNA mitochondrial materno e paterno foi detectada com uma frequência de $0,7 \%$ do total de mitocôndrias do tecido muscular do indivíduo (Kraytzberg e col, 2004). Este achado reforça a idéia de que recombinação é possível, uma vez que a mitocôndria possui uma recombinase funcional (Thyagarajan e col, 1996). Qual a frequência desse fenômeno em humanos é um dado ainda incerto. Entretanto, tudo indica que se a recombinação está presente, sua incidência é provavelmente baixa. Além disso, a ausência de transmissão de mitocôndrias paternas indica que esse fenômeno, se existir, é certamente pouco relevante para os estudos populacionais. Logo, a ausência de recombinação da molécula mitocondrial permanece ainda como uma premissa válida em estudos populacionais.

A correlação entre as diferentes variantes do DNAmt e a geografia é tradicionalmente atribuída a efeitos de deriva genética. Entretanto, diversos estudos passaram a levantar evidências de que essa distribuição das variantes mitocondriais pode ter sido o resultado de seleção natural (Denaro e col, 1981; Wallace e col, 1999; revisão em Wallace, 2007). Para estes autores, o modelo de deriva genética para explicar as diferenças na distribuição das linhagens passou a ser de difícil reconciliação com os dados observados. Como exemplo, os autores citam o fato de que na região nordeste do continente africano, apesar da presença de todas as linhagens africanas, apenas os progenitores das linhagens Euroasiáticas $\mathrm{M}$ e $\mathrm{N}$ deixaram o continente e colonizaram a Eurásia. Além disso, as diferenças de frequências dos haplogrupos A, C, D e E entre a Ásia Central e a Sibéria é difícil de ser explicada apenas por efeito de deriva. Foi sugerido como mais plausível que fatores ambientais tenham favorecido a seleção de certas linhagens mitocondriais à medida que os grupos humanos se dispersavam pelo planeta.

Os genes mitocondriais possuem um papel central na produção de energia, tanto sob a forma de ATP, como sob a forma de calor para manter a temperatura do corpo. Mishmar e col. (2003) especularam que as diferenças encontradas na distribuição de linhagens podem ser reflexo de adaptações para a vida em climas cada vez mais amenos na medida em que os humanos modernos deixavam a África e se dirigiam para a Europa e o nordeste da Ásia. A fim de detectar a possível influência da seleção natural, foram calculadas razões entre as taxas de substituições não-sinônimas e taxas de substituições sinônimas nos genes mitocondriais para as diferentes regiões geográficas. Além disso, a distribuição das linhagens foi comparada com aquela que seria esperada sob a teoria da neutralidade, por 
meio dos testes de Tajima e Fu (Tajima, 1989; Fu e Li, 1993). Se a seleção natural foi um importante fator na moldagem da distribuição das variantes de sequências mitocondriais, então a seleção teria atuado preferencialmente sobre variações de aminoácidos nos polipeptídeos da cadeia de fosforilação oxidativa. Os achados do grupo de Mishmar e col. (2003) corroboram essas especulações. As análises mostraram que as variações no DNA mitocondrial desviaram de uma distribuição esperada admitindo neutralidade para as linhagens Européias, Ásia Central, Sibéria e América, mas não na África. Os genes ATP6, cytb e COI são especialmente variáveis nas zonas ártica, temperada e tropical, respectivamente, e grande parte dessa variação alterou aminoácidos evolutivamente conservados. Se a seleção realmente for o principal fator da distribuição das variantes mitocondriais, a taxa de evolução molecular do DNA mitocondrial não foi, portanto, constante ao longo da história humana. Este fato poderia ter impacto nas estimativas de datação das migrações do homem moderno realizadas por meio do DNAmt.

\section{5 - Diversidade genética do DNA mitocondrial nos brasileiros atuais}

\subsection{1 - Populações Ameríndias}

Informações referentes a ameríndios mostram um padrão heterogêneo nas freqüências dos haplogrupos nas diferentes regiões do país. Os primeiros trabalhos em populações ameríndias brasileiras foram realizados na década de 90. Ao analisar tribos como Yanomami, Macushi, Tikuna e Khrao, juntamente com outras populações da América do Sul, Central e Norte, verificou-se a presença dos quatro principais grupos de haplogrupos ameríndios A, B, C e D. Grande parte dos estudos com indígenas brasileiros concentram-se na região Norte onde se encontra a maior parte das populações indígenas atuais. O que se verifica, geralmente, é uma alta freqüência de haplogrupo C, seguida pelo haplogrupo D e uma baixa frequiência dos haplogrupo A e B (revisão em Salzano, 2002). Um importante trabalho com amostras da região central e norte do país foi realizado por Ward e col. (1996). Foi analisada a região controle do DNAmt de 82 ameríndios provenientes das tribos Xavante, Zoró e Gavião. As duas primeiras tribos estão no Mato Grosso e a terceira, em Rondônia. Todas as linhagens pertenciam a um dos quatro principais haplogrupos ameríndios. De um total de 14 diferentes linhagens, $19 \%$ foram classificadas como 
pertencentes ao haplogrupo A, 44\% ao haplogrupo B, $7 \%$ ao haplogrupo $\mathrm{C}$ e $30 \%$ ao haplogrupo D. Na demais regiões do país, principalmente da costa atlântica, há lacunas na definição da distribuição dos haplogrupos indígenas.

Mendes-Júnior (2005) organizou mapas sul-americanos alternativos de distribuição das frequiências dos haplogrupos ameríndios, incorporando também dados de linhagens indígenas encontradas em populações urbanas e afro-derivadas. De uma maneira geral, é possível observar que no nordeste do Brasil, o haplogrupo B é o mais freqüente. No sudeste do país, o haplogrupo B também prevalece, seguido pelo haplogrupo A. Os haplogrupos C e D, por sua vez, apresentam baixas frequiências. Na região Sul, os haplogrupos B e D apresentam frequiências moderadas e os haplogrupos A e C são pouco freqüentes. Finalmente, no Centro-Oeste, o haplogrupo B se destaca claramente como o mais freqüente e o haplogrupo A é o menos freqüente.

No trabalho de Silva Jr. e col. (2002) com 40 indivíduos, grande parte indígenas brasileiros pertencentes a 8 etnias (Yanomama, Arara, Waiampi, Tyrio, Poturujara, Katuena, Kayapo e Guarani), foi detectada a maior prevalência dos haplogrupos A e B, seguidos pelo haplogrupo $\mathrm{C}$ e finalmente pelo haplogrupo $\mathrm{D}$. Outro trabalho com populações indígenas foi realizado por Brandão-Ferreira (2006) com 184 indígenas pertencentes a seis aldeias Pataxó, localizadas no extremo sul da Bahia. Todos os quatro principais haplogrupos ameríndios foram detectados em todas as comunidades Pataxó, com exceção do haplogrupo $\mathrm{D}$ em uma delas. $\mathrm{O}$ haplogrupo $\mathrm{X}$ não foi identificado. Recentemente, Marrero e col. (2007) analisaram o DNAmt de 278 amostras de indivíduos de duas tribos indígenas, Guarani e Kaigang, localizadas em 6 reservas indígenas nas regiões central e sul do país (Mato Grosso do Sul, Paraná e Rio Grande do Sul). Dentre os 200 indivíduos Guarani analisados, três dos quatro haplogrupos ameríndios foram identificados, prevalecendo o haplogupo A (84\%), seguido pelo haplogrupo C $(9,5 \%)$ e D (6,5\%). O haplogrupo B não foi detectado, o que contrasta com sua presença em estudos realizados com outras tribos Tupi na América do Sul (Schmitt e col, 2004). Nas 78 amostras analisadas de Kaigang, predominou o haplogrupo C (46\%), seguido pelo haplogrupo A (42\%) e B (5\%). O haplogrupo D não foi detectado. 


\subsection{2 - Populações Urbanas Predominantemente Brancas}

Um importante estudo foi realizado com brasileiros brancos de diferentes regiões urbanas, com uma amostra de 247 indivíduos (Alves-Silva e col, 2000). Os resultados indicaram uma diversidade muito grande de haplótipos mitocondriais. Os DNAs das mitocôndrias tiveram, em todas as regiões estudadas, uma frequência das diferentes origens geográficas relativamente uniforme: $33 \%$ de linhagens ameríndias, 28\% de linhagens africanas e 39\% de européias. Os haplogrupos europeus mais comuns foram o H (44\%), T (14\%) e J (11\%), sugerindo uma origem predominantemente da Europa Ocidental; 49\% da contribuição total africana foi devida principalmente aos haplogrupos L3e e L1c, freqüentes em populações da África central (Mateu e col, 1997). Os haplogrupos L3d e L1b, específicos da região ocidental do continente africano, foram detectados conjuntamente em $10 \%$ do total da contribuição africana. Poucos haplótipos específicos da África oriental foram encontrados nesse estudo, sugerindo que a maioria das linhagens africanas no Brasil são oriundas principalmente da África centro-ocidental, incluindo Camarões e Angola. Foram encontrados os quatro haplogrupos ameríndios (A, B, C e D) entre os brasileiros brancos, sendo o haplogrupo A o mais freqüente. Entretanto, a distribuição dessas linhagens nas diversas regiões do país não se mostrou uniforme. Na região Norte, o haplogrupo C era o mais freqüente e ele era o menos freqüente no Nordeste. Em 2005, Marrero e col. analisaram o DNA mitocondrial de 119 indivíduos classificados como brancos de diversas localidades do estado do Rio Grande do Sul. Apesar do predomínio das linhagens européias, a fração de linhagens ameríndias atingiu 36\% e as linhagens africanas atingiram uma freqüência de $16 \%$.

O que se conclui desses estudos é que, embora durante os 500 anos de colonização o número de indígenas tenha diminuído drasticamente, uma porcentagem significativa de linhagens ameríndias foram assimiladas pela população branca. Os brancos brasileiros guardam grande parte da história da variabilidade do DNAmt indígena. Portanto, é possível, ao se analisar a população de uma região qualquer, ter uma idéia da variabilidade do DNAmt dos índios que viveram naquela região.

Vale a pena destacar também outros quatro estudos brasileiros com populações urbanas

miscigenadas (tri-híbridas). Os três primeiros foram realizados com amostras da região Amazônica e o quarto da região Nordeste do país. Na população de Belém, Santos e col. 
(1999) encontraram importante assimilação de mitocôndrias ameríndias (57,5\%). Marinho (2004) estudou também amostras de Belém e observou uma contribuição ameríndia ainda maior, de 64,5\%. Feio-dos-Santos e col. (2006) investigaram 150 amostras não aparentadas da população de Santarém em relação ao DNA mitocondrial. Os resultados demonstraram também uma elevada contribuição de linhagens ameríndias (83,5\%), distribuídas entre os 4 principais haplogrupos (A-D), seguida de linhagens africanas $(14 \%)$ e européias $(2,5 \%)$. Barbosa e col. (2008) estudaram as regiões hipervariáveis 1 e 2 do DNAmt de amostras provenientes de Alagoas. Com base nos resultados, um quadro distinto foi identificado em relação às populações urbanas amazônicas: $45 \%$ das sequências puderam ser classificadas como haplogrupos africanos, $27 \%$ como nativo-americanos e $25 \%$ como europeus, indicando a presença mais frequente das linhagens africanas.

\subsection{3 - Populações Afro-descendentes}

Estudos realizados com populações afro-brasileiras da Amazônia, comunidades remanescentes de quilombos, evidenciaram elevadas freqüências de linhagens mitocondriais africanas (L1, L2 e L3) seguidas pelas linhagens ameríndias (A, B, C e D). A detecção de haplogrupos europeus é pouco expressiva (Ribeiro-dos-Santos e col, 2002; Ribeiro-dos-Santos e col, 2007; Carvalho e col, 2008). Estes estudos indicaram que as populações quilombolas tornaram-se informativas também no que concerne à investigação da variabilidade indígena.

Abê-Sandes (2002) ao analisar duas comunidades remanescentes de quilombos no estado da Bahia, Barra e São Gonçalo, observaram ausência da contribuição européia e contribuição ameríndia variando de 6 a 22\%, porcentagem inferior quando comparada as análises com remanescentes do norte do país. Silva Jr. e col. (2006) analisaram o DNA mitocondrial de indivíduos pertencentes a duas populações africanas (Congo e Camarões) e quatro populações afro-brasileiras (quilombos de Cametá, Trombetas, Cajueiro e "negros" da cidade de Ribeirão Preto). Segundo esses estudos, $80 \%$ dos indivíduos vieram da região Centro-Oeste africana, $15 \%$ do Oeste e 5\% do Leste. Brandão-Ferreira, também em 2006,

analisou 208 indivíduos pertencentes a quatro remanescentes de quilombos. Três eram localizados na região nordeste (Mocambo, Sacutiaba e Rio das Rãs) e quarto era localizado no Centro-Oeste brasileiro (Kalunga). Todas as comunidades apresentaram um padrão 
similar: L2a e L3e foram os haplogrupos mais freqüentes, seguidos dos haplogrupos L0a, L1c, L2b e L3d. Os quatro principais haplogrupos ameríndios (A, B, C e D) foram também detectados.

Bortolini e col. (1997) estudaram 42 indivíduos afro-brasileiros de duas populações urbanas, Porto Alegre, e Salvador. Este estudo, em contraste com os realizados com quilombolas, evidenciou maior freqüência de linhagens mitocondriais africanas. Variantes das linhagens encontradas no trabalho foram descritas previamente em Senegal (Graven e col, 1995), populações da etnia Banto (Soodyall e col, 1996) e Pigmeus (Vigilant e col, 1991). Apenas 5 linhagens foram identificadas como sendo ameríndias. A baixa assimilação relativa de linhagens ameríndias sugere pouca miscigenação com indígenas nas cidades.

Recentemente, Gonçalves e col. (2008) estudaram o DNA mitocondrial de 120 indivíduos afro-descendentes da cidade de São Paulo. De maneira similar ao trabalho de Bortolini e col (1997) e em contraste com os dados obtidos com quilombos, foi detectada alta frequência de linhagens mitocondriais africanas: 102 apresentaram linhagens africanas (85\%), 14 apresentaram linhagens ameríndias (11,7\%) e apenas 3 indivíduos apresentaram linhagens européias $(2,5 \%)$. As linhagens identificadas coincidiram com aquelas detectadas em populações nativas da África Ocidental (Kanuri, Yoruba, Senegal, Serer, Wolof, Mandenka, Mende, Loko, Limba, Temne, Guiné-Bissau e Hausa) e África CentroOcidental (Angola, Fang, Cabinda, Bakaka e Bassa) e África Oriental (Moçambique).

\section{6 - Ocupação Humana do Brasil}

Os brasileiros constituem uma das populações mais heterogêneas do mundo. São o resultado de cinco séculos de miscigenação interétnica de populações provenientes de três continentes: os colonizadores europeus, representados principalmente pelos portugueses, os escravos africanos e as comunidades indígenas.

No Brasil, ainda hoje, existem populações semi-isoladas de ameríndios e afrodescendentes que preservam, em graus variados, seus aspectos culturais e genéticos. Essas populações constituem-se importantes fontes de informação sobre os grupos étnicos

fundadores da população brasileira. Para os geneticistas, um grupo populacional é considerado isolado quando está separado de outros grupos por barreiras geográficas, 
políticas, sócio-culturais ou religiosas que impedem ou dificultam a troca de genes com outras populações (Beiguelman, 1994). Além do valor histórico, o estudo de populações isoladas ou semi-isoladas é de grande importância médica. Em relação à genética médica, o estudo dessas populações é relevante no mapeamento de doenças genéticas ou no estudo de doenças recessivas, como por exemplo, a retinite pigmentosa na população finlandesa ou a doença de Tay-Sachs em judeus Ashkenazi (Vogel e Motulsky, 2000).

A seguir será apresentada uma breve revisão histórica sobre a origem dos principais grupos populacionais que formaram a sociedade brasileira (europeus, ameríndios e africanos) e os principais aspectos do processo de interação entre esses grandes grupos étnicos em território brasileiro. Esta revisão foi realizada após uma compilação de informações provenientes de diversas fontes, como Salzano e Freire-Maia (1970), Carneiro da Cunha (1992), Monteiro (1994), Ribeiro (1995), Bethell (1997), Florentino (1997), Sans (2000), Alpers (2000), Bezerra-Neto (2001), Del Priori (2001) e Klein (2002).

\subsection{1 - O Colonizador Português}

Durante os primeiros cinquenta anos após a descoberta do Brasil, a ocupação portuguesa no território brasileiro foi mínima. Organizados em poucas feitorias dispersas ao longo do litoral, dependiam dos indígenas para alimentação e proteção. Neste período, a presença portuguesa e mesmo de outros grupos europeus, como espanhóis e franceses, consistiu nos chamados degredados. Esses indivíduos, condenados e banidos de suas terras natais, além de aventureiros em busca de enriquecimento fácil, deixaram para trás mulheres e filhos.

No período colonial, a ocupação do Brasil constituiu um problema de difícil solução para Portugal. Sua população, na época, era pouco superior a um milhão de habitantes e não tinha condições de atender as demandas das colônias portuguesas na África, Ásia e América. Além disso, segundo alguns historiadores, entre os portugueses que vinham para o Brasil, a proporção era de oito ou nove homens para cada mulher. Portugal tinha a preocupação da posse da terra. A união entre homem europeu e mulher indígena tornou-se corriqueira e mesmo encorajada oficialmente como estratégia para o aumento populacional, necessário ao processo de ocupação das terras. A partir da segunda metade do século XVI, essas uniões se intensificaram também com escravas africanas. Indícios históricos mostram 
que nos tempos da colônia prevaleciam os relacionamentos sexuais entre os colonizadores europeus, que vinham em grupos de muitos homens e poucas mulheres, e as mulheres nativas (ameríndias) ou trazidas como escravas da África.

A economia colonial teve início a partir de 1531 com a expedição de Martim Afonso de Souza e seguiu o modelo do cultivo de cana-de-açúcar, construção de engenhos e uso de mão-de-obra escrava. Começava assim a caça ao indígena e, logo em seguida, o tráfico de "negros da terra", termo utilizado para diferenciá-los dos negros africanos, a fim de abastecer os núcleos de colonização.

A imigração européia, principalmente portuguesa, foi estimada em aproximadamente 500.000 indivíduos entre os anos de 1500 e 1808. Após a abertura dos portos às nações amigas, o Brasil passou a receber também um número crescente de imigrantes de diversas partes do mundo. Entretanto, a fonte portuguesa se manteve em destaque, seguida pelos italianos, espanhóis e alemães.

\subsection{2 - Os Nativos brasileiros}

As estimativas sobre a densidade populacional indígena presente antes da chegada do colonizador português variam entre diversos historiadores. Os números oscilam de 1,0 a 8,5 milhões para a América do Sul e de 1,0 a 6,8 milhões para o Brasil. Entre essa vasta população, desenvolveram-se civilizações heterogêneas entre as quais podemos citar os xavantes, caraíbas, tupis, jês e guaranis.

A presença dos índios no território brasileiro é muito anterior ao processo de ocupação pelos exploradores europeus. Especulações arqueológicas recentes, com base em restos de fogueira pré-históricas, sugerem que, há cinquenta mil ou quarenta mil anos antes do presente, grupos humanos já poderiam estar na serra da Capivara, no Piauí. Outras datações situam esse limite para dez ou nove mil anos antes de Cristo. Os vestígios materiais, em resumo, indicam a existência de uma cultura indígena instalada em solo brasileiro pelo menos há milhares de anos antes da chegada de Cabral.

Em geral, o maior contato desenvolvido entre índios e europeus aconteceu nas faixas litorâneas do nosso território, onde predominavam os povos indígenas pertencentes ao grupo tupi-guarani. Desde o contato com o europeu, as tribos ameríndias sofreram um 
drástico declínio demográfico devido aos conflitos e doenças às quais eles não tinham resistência. Os povos que habitavam a costa, na maioria falantes de línguas do Tronco Tupi, foram dizimados, dominados ou refugiaram-se nas terras interioranas para evitar o contato. Atualmente, existem cerca de 300.000 ameríndios no Brasil, vivendo em reservas protegidas pelo Governo Federal.

\subsection{3 - Os Africanos}

A chegada dos africanos da África Negra em território brasileiro teve início na metade do século XVI. Desde o início vieram em grande número e não se tem a data exata da chegada do primeiro navio. O mais antigo registro que se tem notícia é a data de 1532, com a chegada do navio capitaneado por Tomé de Souza.

O Brasil absorveu cerca de 39\%, aproximadamente 4 milhões de indivíduos, dos cerca de dez milhões de escravos que foram trazidos para a América entre os séculos XVI e XIX. Esses escravos vinham principalmente das colônias portuguesas na África, localizadas no Congo, Angola, Moçambique, Senegal e Gâmbia, além da região de Benin e Nigéria.

Registros históricos, ainda que incompletos, indicam que a grande maioria dos escravos africanos veio da região do Congo e Angola, ou seja, do Centro-Oeste da África, onde os portugueses já haviam estabelecido colônias desde o século XVI. Esta foi a única região que manteve um fluxo constante de escravos durante todo o período do tráfico. Acredita-se que entre 1701 e 1810, mais de dois terços dos africanos importados pelo Brasil tenham vindo desta região, e apenas um terço teria vindo de portos da África Ocidental.

A região de Moçambique, na África Oriental, só passou a exportar escravos no século XIX, devido a várias dificuldades, como alto custo dos transportes, a rota mais distante e a fraca penetração portuguesa no interior do continente. Os escravos de Moçambique foram enviados principalmente para o Rio de Janeiro e daí distribuídos para Minas Gerais e para estados mais ao sul (Figura 3).

A região de Senegal e Gâmbia teria tido participação mais ativa no tráfico somente durante o século XVIII, quando guerras santas entre os estados muçulmanos da região criaram um mercado em massa de escravos. 
As colônias da Baía de Benin enviaram muitos africanos para os portos de Salvador e Recife durante os séculos XVI e XVII, mesmo depois da tomada da região pelos holandeses. Esta região, juntamente com Congo e Angola, foi a fonte mais importante de escravos durante o início e fim do século XVIII.

Entre os escravos que habitavam o Brasil, havia uma grande diferença nas proporções entre as faixas etárias e entre os sexos. Devido à alta mortalidade durante a travessia do Atlântico, eram selecionados principalmente jovens saudáveis. Cerca de $80 \%$ dos escravos vendidos eram adultos, e destes, dois terços eram homens.

Apesar da baixa fecundidade da população escrava, essa população cresceu no Brasil com o passar do tempo, mantendo as mesmas características, provável resultado de um constante fluxo de novos escravos devido ao tráfico. Os negros trabalhavam em média 18 horas por dia, não podiam casar e ter filhos. Em função das precárias condições de vida e trabalho, os escravos africanos sobreviviam, em média, apenas 10 anos no território brasileiro.

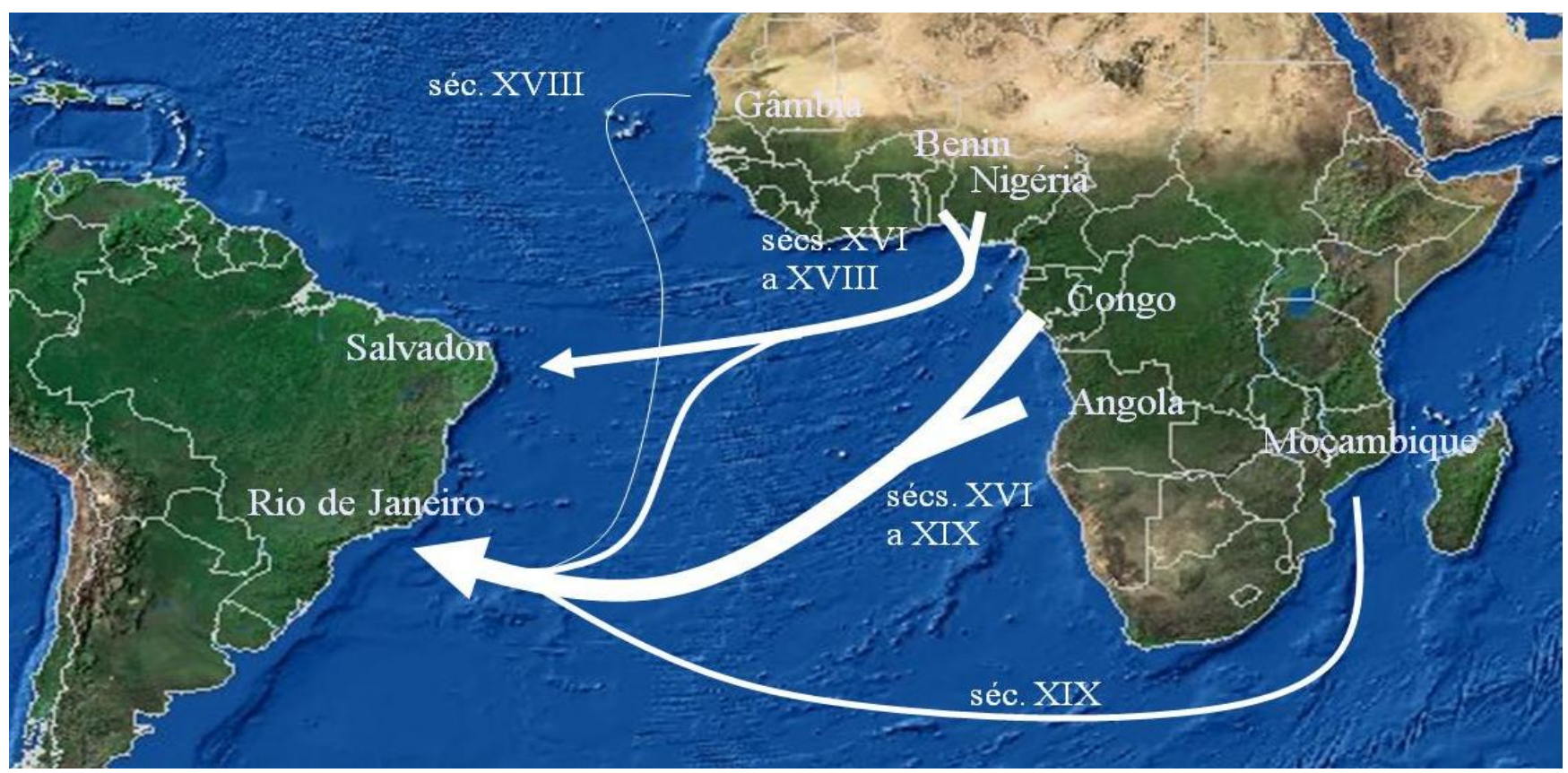

Figura 3 - Representação esquemática das principais rotas e períodos do tráfico de escravos entre o continente africano e o território brasileiro (baseado em Curtin, 1969; Klein, 2002). 


\section{7 - Os Remanescentes de Quilombos}

Como estratégias de defesa aos maus tratos e aos pesados serviços que lhes eram impostos, muitos negros africanos fugiram das senzalas e se organizaram em comunidades denominadas de quilombos ou mocambos, fundados em regiões de difícil acesso (Azevedo e Castro, 1998; Bezerra-Neto, 2001).

As comunidades quilombolas, quanto ao espaço físico, podem ser definidas simplesmente por um agrupamento de africanos. Economicamente, os quilombos eram locais onde os africanos desenvolveram o extrativismo e pequenas plantações comunitárias além de realizar a troca e a venda de seus produtos em cidades vizinhas. Além disso, os quilombos detinham um significado de resistência e de auto-afirmação do grupo negro diante da ordem escravista (Azevedo e Castro, 1998).

Segundo a Associação Brasileira de Antropologia (ABA), atualmente o termo quilombo se refere a toda comunidade negra rural que agrupe descendentes de escravos vivendo da cultura de subsistência e onde as manifestações culturais têm forte vínculo com o passado (Oliveira Jr. e col, 2000). Esta definição passa a incluir não somente negros fugidos, mas também aqueles libertos ou abandonados pelos seus senhores.

Da época da formação dos primeiros quilombos até o presente momento, muitas comunidades foram extintas, porém outras persistiram. Alguns quilombos miscigenaram-se com populações vizinhas e outros permaneceram em relativo grau de isolamento, preservando, em parte, a sua identidade biológica e cultural. Um levantamento feito pelo CIGA da UnB (Centro de Cartografia Aplicada e Informação Geográfica da Universidade de Brasília) e coordenado pelo geógrafo Rafael Sanzio mostrou que existiam, em 2005, 2.300 comunidades quilombolas no Brasil. Uma nova estimativa em 2008 elevou este número para mais de 3.000 comunidades. Até o fim de 2008, foram emitidas 1.087 certidões, que reconhecem 1.305 comunidades (www.pnud.org.br).

\subsection{1 - Remanescentes de quilombos do Vale do Ribeira - São Paulo}

A descrição da ocupação do Vale do Ribeira e da origem dos remanescentes de quilombos que se segue foi baseada no trabalho de Paes (2009) e de informações coletadas

nos seguintes portais: Fundação Nacional do Índio (FUNAI - http:// www.funai.gov.br), 
Instituto Socio Ambiental (ISA - http://www.socioambiental.org) e Instituto de Terras do Estado de São Paulo (ITESP - http://www.itesp.sp.gov.br).

O Vale do Ribeira é uma região localizada no extremo sul do estado de São Paulo, limitando-se ao sul e sudoeste com o estado do Paraná, a leste com o oceano Atlântico e a oeste e noroeste com a serra de Paranapiacaba. Esta região concentra os maiores remanescentes de Mata Atlântica do Estado, tendo cerca de $60 \%$ de seu território coberto por vegetação natural. Geograficamente, o Vale do Ribeira pode ser dividido em três regiões: a Baixada do Ribeira, englobando os municípios de Eldorado, Jacupiranga, Pariquera-Açu, Registro e Sete Barras, a região sub-litorânea, envolvendo os municípios de Cananéia e Iguape, e o Alto do Ribeira, compreendendo os municípios de Ribeira, Iporanga e Apiaí. O Rio Ribeira de Iguape nasce na Serra das Almas, no município de Serro Azul, no Estado do Paraná. Suas águas penetram pelo estado de São Paulo por meio do vale formado entre as Serras Agudos Grande e Caroca, no município de Apiaí. O rio segue paralelo à Serra do Mar e deságua no oceano Atlântico, no município de Iguape.

A ocupação humana dessa área remonta ao período pré-colombiano e é antiga como testemunham numerosas evidências de sambaquis presentes em toda a faixa litorânea, principalmente em torno de Cananéia e Ilha Comprida.

Antes da chegada de europeus, o litoral da região era povoado pelos Guaianás, e ao sul de Cananéia pelos Carijós. A região era fracamente povoada, com poucos e pequenos agrupamentos indígenas localizados no litoral e nas margens do Rio Ribeira. Esta região também foi zona de passagem de ameríndios que no inverno desciam do Planalto para o litoral em busca de áreas onde pudessem pescar.

Atualmente, a Fundação Nacional do Índio (FUNAI) estima que a população indígena na região tenha cerca de 400 indivíduos organizados em dez aldeias. A presença do povo Guarani no Vale do Ribeira é marcada atualmente por intensa mobilidade de sua população, em parte, à falta de regularização fundiária de seus territórios tradicionais, que muitas vezes são sobrepostos a unidades de conservação. No censo de 2000, o IBGE levantou a existência de uma população de 63.789 indígenas no estado de São Paulo. Desse total, cerca de 4.000 indígenas, dos povos Guarani, Kaigang, Terena e Krenak, residem em 31 Terras Indígenas, localizadas na Capital, na Baixada Santista, no Litoral Norte, no Oeste Paulista, no Vale do Ribeira e no Complexo Estuarino Lagunar Cananéia-Iguape. 
A chegada dos europeus no Vale do Ribeira ocorreu logo após os primeiros anos da descoberta do Brasil, com a esquadra de Martim Afonso de Souza ao aportar nas imediações de Cananéia, em 12 de agosto de 1531.

Acreditando ser esta região favorável para a conquista de riquezas minerais, a primeira bandeira rumo ao interior foi comandada por Pedro Lobo no dia 1 de setembro de 1531 . O Rio Ribeira de Iguape era o caminho natural para as bandeiras em busca de ouro e foi percorrido por diversas expedições desde o século XVI, partindo de Iguape e Cananéia. As expedições exploravam não apenas o rio Ribeira, mas também seus afluentes, formando vários núcleos populacionais pelo caminho. O primeiro núcleo oriundo dessas expedições foi Xiririca, atual Eldorado. Esses núcleos aliavam mineração com agricultura de subsistência e muitas vezes surgiram em locais anteriormente ocupados por aldeias indígenas. Com o aumento da frequência das incursões, outros núcleos populacionais foram formados rio acima, como Ivaporunduva, Iporanga e Apiaí.

Além da busca de metais preciosos, os bandeirantes também se dedicaram ao apresamento e a comercialização de indígenas. Sua importância diminuiu ao longo do tempo e já no ano de 1806 os indivíduos escravizados eram majoritariamente negros africanos. Embora a maior concentração de escravos estivesse em Iguape, contingentes negros oriundos principalmente de Guiné, Angola e Moçambique, foram levados a outras localidades Ribeira acima.

A partir do século XVII, a mineração na região deva seus primeiros sinais de declínio. A razão principal dessa queda, além de indícios de rápido esgotamento das jazidas, foi a descoberta de ouro em Minas Gerais, em 1697, e o consequente êxodo de mineradores do Vale do Ribeira para essa região. $\mathrm{O}$ abandono, entretando, não foi total e a extração de ouro permanceu ainda durante algum tempo. O ponto crítico foi atingido em 1763, quando a Casa da Moeda em Iguape foi fechada. Nesse período, os registros históricos indicam uma gradativa saída da população branca da região, sendo os escravos negros adquiridos no auge da mineração alforriados ou simplesmente abandonados. Além do abandono ou da alforria, tanto indígenas como os negros africanos apresentaram formas de resistência a escravidão. Uma dessas formas foram as fugas, as quais foram favorecidas pela geografia da região, com sua densa mata, vales e serras servindo como zonas de refúgio. 
No final do século XVIII a agricultura ganha impulso na região e o arroz desponta como gênero de destaque. A economia local se dinamizou e houve aumento da importação de escravos para a região. Após o auge, em 1850, a região do Vale entra em novo período de decadência que se agrava com a fracassada tentativa de implantação de cultivos de café. Em seguida, a perda da função portuária de Iguape para Santos, o prolongamento da estrada de ferro Sorocabana e a construção da ferrovia Santos-Jundiaí na metade do século XIX impediram uma recuperação econômica da região do Vale do Ribeira, agravando seu isolamento econômico que perdura até os dias de hoje.

A ocupação da região pelos negros foi marcada por intensa mobilidade geográfica, que caracterizou a extração de ouro de lavagem, e absorção expressiva de mão-de-obra escrava por pequenas roças de subsistência. O fim da mineração e a saída da presença branca na região ampliou a presença da população negra na localidade. A área se transformou em um importante ponto de fuga de um grande contingente de negros livres, libertos ou fugidos.

Os negros transformados em pequenos agricultores desbravaram novos lugares promovendo um repovoamento da região. A população negra que se manteve livre durante o período escravista ocupou o Vale do Ribeira em uma extensa área de continuidade geográfica.

De acordo com a o Instituto Sócio-Ambiental, podem existir até cinquenta e dois povoados remanescentes de quilombos no Vale do Ribeira. Segundo o Instituto de Terras do Estado de São Paulo, foram identificadas até o momento nessa região 25 comunidades e destas seis comunidades já receberam os títulos de suas terras: Ivaporunduva, São Pedro, Pedro Cubas, Pilões, Maria Rosa e Galvão.

A localização geográfica do Vale do Ribeira e das populações estudadas pode ser observada nas Figuras 4 e 5. As Figuras $6 a$ e 6 b apresentam imagens características do ambiente e do tipo de habitação encontrada nas comunidades que foram por nós estudadas. A investigação dessas comunidades pode resgatar parte da história do Brasil, assim como, auxiliar em um melhor entendimento de como os africanos contribuíram para a formação da população brasileira. 


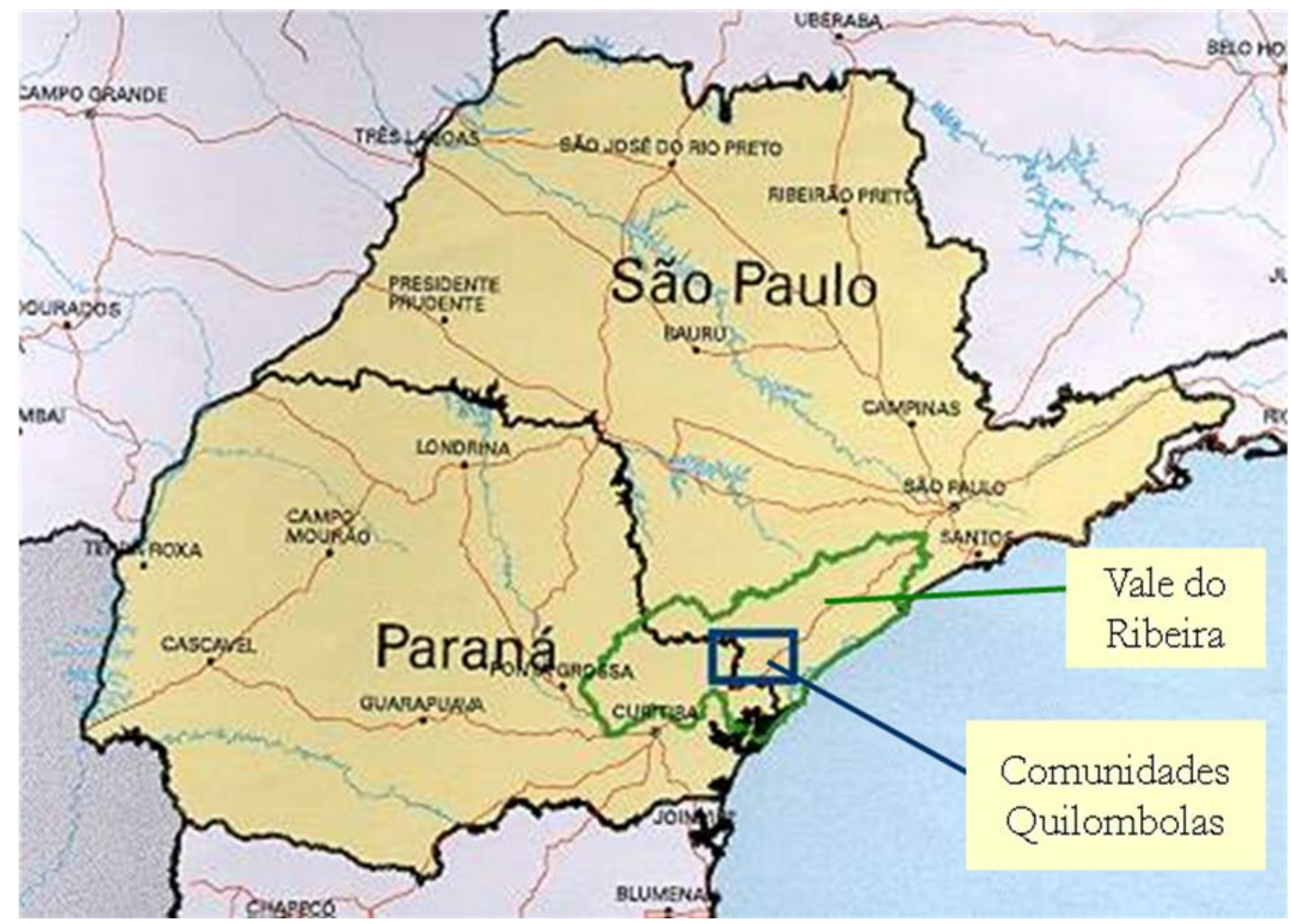

Figura 4 - Mapa dos estados de São Paulo e Paraná. Em verde, a área do Vale do Ribeira. No quadrado azul, a área corresponde à Figura 5, onde se encontram os remanescentes de quilombos (Fonte: ISA - Instituto Socioambiental).

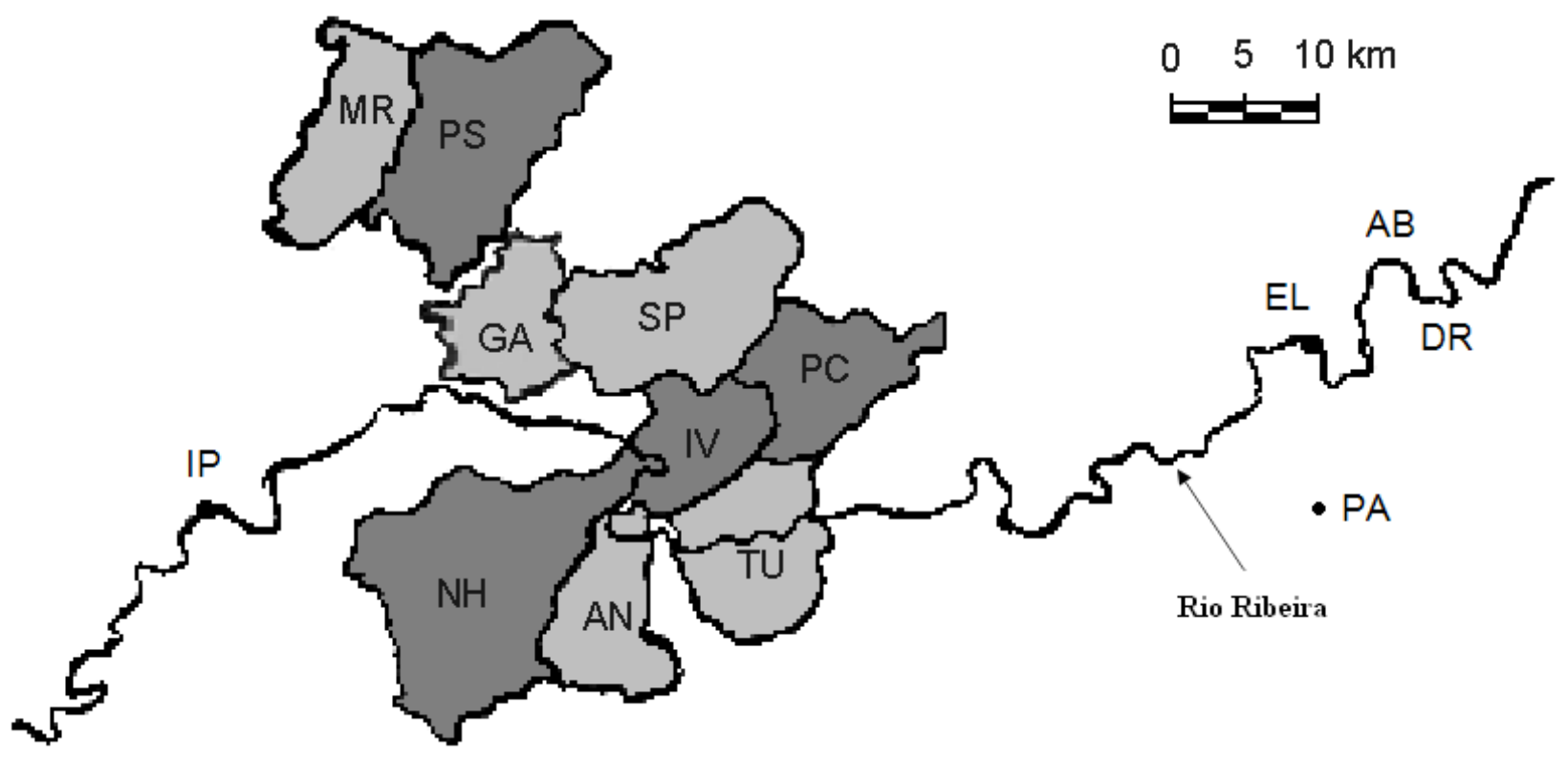

Figura 5 - Localização geográfica das comunidades remanescentes de quilombos na região do Vale do Ribeira. As siglas AB, DR, NH, AN, TU, IV, PC, SP, GA, PS, MR e PA indicam as populações investigadas de Abobral Margem Esquerda, Abobral Margem Direita, Nhunguara, André Lopes, Sapatu, Ivaporunduva, Pedro Cubas, São Pedro, Galvão, Pilões, Maria Rosa e Poça, respectivamente. As populações estudadas encontram-se nas imediações dos municípios de Eldorado (EL) e Iporanga (IP). 


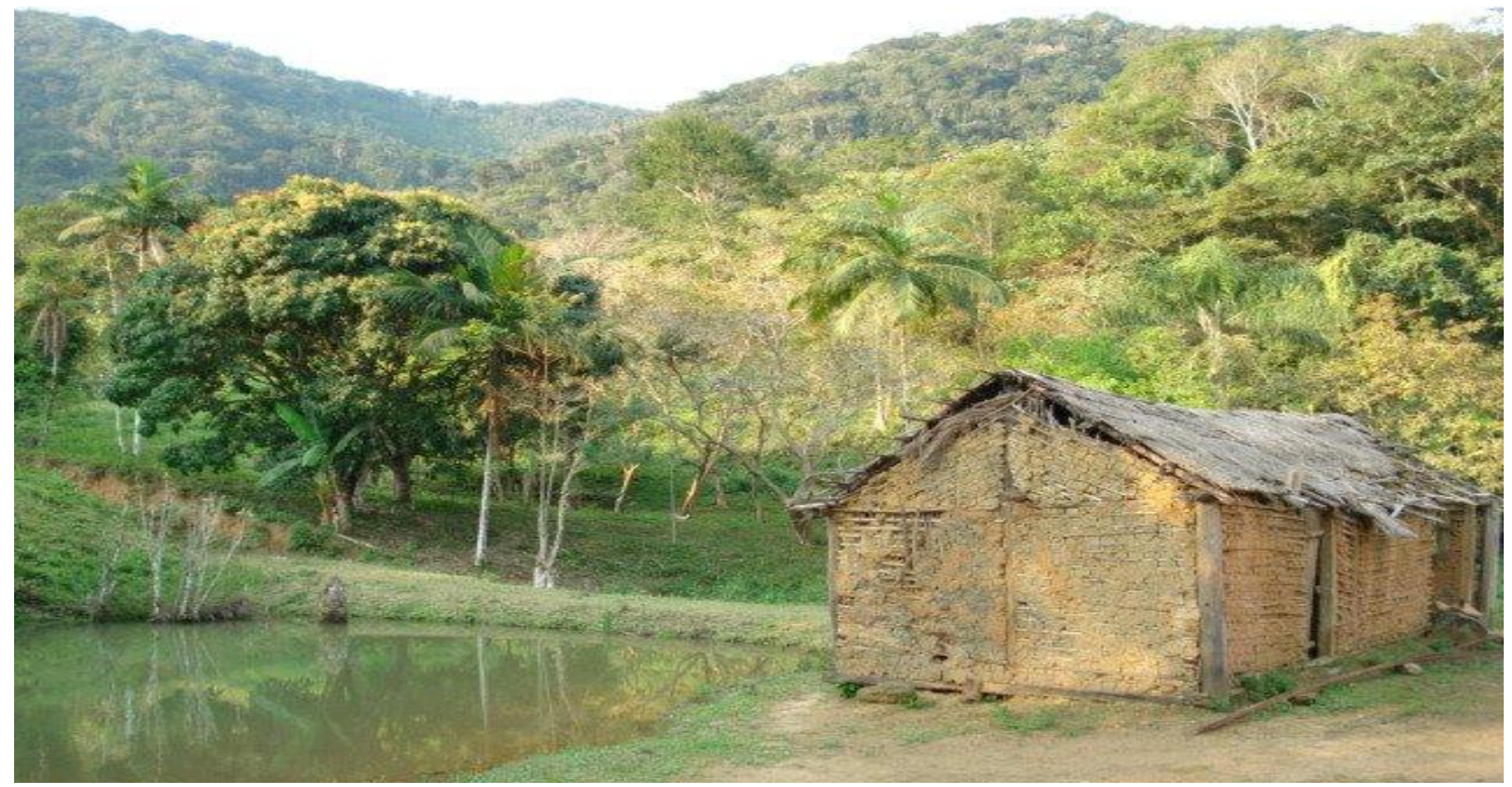

Figura 6a-Casa característica das comunidades de quilombos (quilombo de Nhunguara).

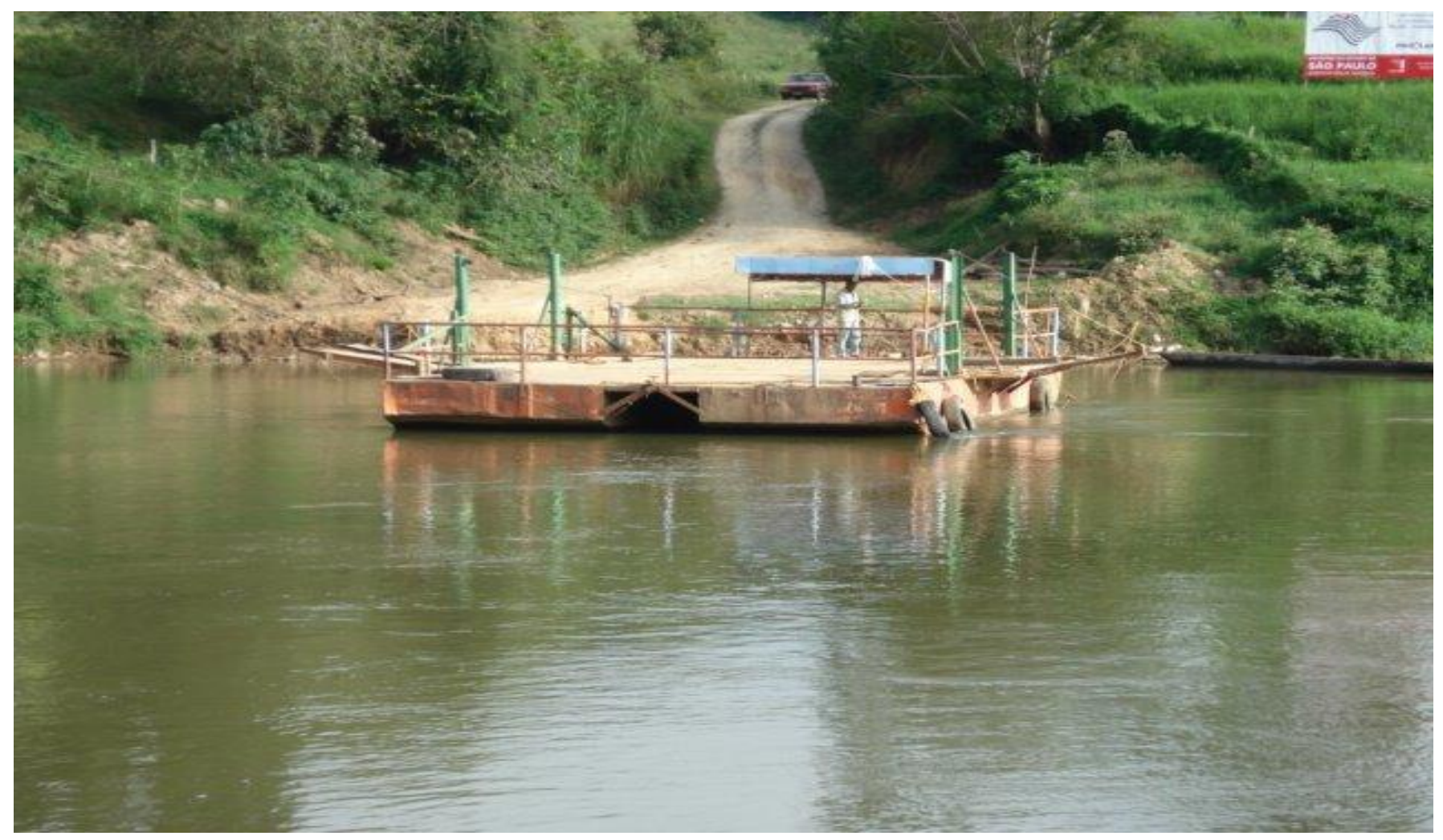

Figura $6 \mathbf{b}$ - Balsa utilizada para chegar às comunidades de Pilões e de Maria Rosa. 


\section{2 - OBJETIVOS}




\section{2 - Objetivos}

O objetivo desse estudo é contribuir para o conhecimento da estrutura e da história da formação populacional das comunidades remanescentes de quilombo da região do Vale do Ribeira, por meio de estudos de DNA mitocondrial.

Para atingir esse objetivo pretendemos executar as seguintes etapas:

(i) Identificar as origens geográficas das linhagens de DNA mitocondrial.

(ii) Realizar estimativas de mistura étnica.

(iii) Descrever e medir a diversidade genética dessas populações presente nas linhagens de DNA mitocondrial.

(iv) Comparar o conjunto de resultados obtidos, tanto em relação à freqüência dos haplogrupos como à identidade das seqüências dos haplótipos, com os de outras populações de origem africana e indígena e realizar inferências sobre a origem dos indivíduos fundadores dessas populações.

(v) Comparar os resultados com os registros históricos.

Para alcançar as metas acima listadas, os resultados obtidos nos remanescentes de quilombos também foram comparados com os de uma amostra etnicamente heterogênea colhida na cidade de São Paulo. Além disso, foram realizadas diversas comparações com outras populações descritas na literatura, especialmente ameríndias, africanas e afroamericanas. 


\section{3 - MATERIAIS E MÉTODOS}




\section{3 - Materiais e Métodos}

Este projeto iniciou-se no contexto de um projeto maior intitulado "Variabilidade molecular em populações brasileiras: um estudo do cromossomo X frágil" (processo FAPESP 99/11698-0), conduzido de 2000 a 2003, e que continua até o presente, com modificações nos objetivos, financiado pelo CEPID - Centro de Estudos do Genoma Humano e pelo CNPq.

Diversos estudos genéticos com as populações remanescentes de quilombos já foram e ainda são conduzidos no nosso laboratório: estudos sobre variabilidade genética na síndrome do X frágil, anemia falciforme, fatores genéticos associados à obesidade e à hipertensão, estudos populacionais e de mistura étnica com polimorfismos autossômicos (inserção de Alu) e de cromossomo Y.

\subsection{Amostras}

A coleta de sangue para extração de DNA foi realizada durante cerca de 30 expedições, realizadas a doze populações remanescentes de quilombos do Vale do Ribeira (SP), com duração de 3 a 5 dias cada uma. As viagens foram realizadas no período entre julho de 2000 a outubro de 2008. Cada indivíduo assinou um termo de consentimento autorizando o uso de seu sangue para estudos genéticos e foi também submetido a uma entrevista a fim de serem obtidos dados para a construção de genealogias completas das populações estudadas. Todos os indivíduos, incluindo adultos e crianças, foram também submetidos a exames clínicos e laboratoriais, que incluíam a verificação do peso e da altura e outros parâmetros antopométricos, da pressão arterial, da glicemia e da taxa de hemoglobina no sangue. As etapas mais recentes do estudo foram conduzidos em colaboração com o Laboratório de Cardiologia Molecular - INCOR, coordenado pelo Prof. Dr. José Eduardo Krieger.

Todas as pesquisas foram conduzidas sob a aprovação do Comitê de Ética do Instituto de Biociências e do Comitê de Ética do Instituto de Ciências Biomédicas, ambos da Universidade de São Paulo. Para estudos genéticos e populacionais, foram coletadas amostras de sangue periférico para extração de DNA somente dos indivíduos adultos.

O total de indivíduos adultos de cada população estudados no presente trabalho está representado na Tabela I. Este total para cada comunidade foi obtido após a exclusão de 
indivíduos que não foram considerados quilombolas e cujo material genético foi, portanto, considerado como externo. Esta exclusão foi realizada com o auxílio das entrevistas realizadas com os indivíduos de cada comunidade estudada. Foram excluídos os indivíduos cujos pais não nasceram nos quilombos. Entretanto, os indivíduos que nasceram fora, mas que se casaram com indivíduos dos quilombos e que deixaram descendentes que vivem nos quilombos permaneceram na amostra do estudo.

Tabela I - Populações, número de adultos e o total de habitantes de cada uma das populações estudadas (Total de amostras: 939).

\begin{tabular}{|c|c|c|c|c|c|}
\hline População & Amostras & $\begin{array}{c}\text { Total } \\
\text { Habitantes } \\
\end{array}$ & População & Amostras & $\begin{array}{c}\text { Total } \\
\text { Habitantes } \\
\end{array}$ \\
\hline Abobral Margem Esquerda & 100 & 397 & Abobral Margem Direita & 41 & 176 \\
\hline Galvão & 58 & 143 & André Lopes & 107 & 320 \\
\hline São Pedro & 65 & 132 & Nhunguara & 123 & $\cong 400$ \\
\hline Pedro Cubas & 100 & $\cong 300$ & Sapatu & 95 & $\cong 300$ \\
\hline Pilões & 49 & 128 & Ivaporunduva & 133 & $\cong 300$ \\
\hline Maria Rosa & 19 & 56 & Poça & 49 & $\cong 120$ \\
\hline
\end{tabular}

(Fonte: www.itesp.org.br; Pedroso Jr. e col, 2008)

A localização das populações estudadas no presente trabalho está apresentada na Figura 5 (página 35).

Este trabalho incluiu também uma amostra de indivíduos da cidade de São Paulo $(n=104)$, obtida de indivíduos fenotipicamente normais, averiguados como amostra controle do projeto de doutorado de Ronaldo Serafim Abreu Silva (Abreu-Silva, 2008). Essa amostra foi utilizada como população de referência nas análises filogenéticas. Os indivíduos desta amostra etnicamente miscigenada eram condutores de transporte coletivo urbano, metalúrgicos e funcionários de uma gráfica de grande porte, todos oriundos da cidade de São Paulo. Foram classificados, em grupos de acordo com sua etnia em "brancos", "pardos", "negros", "indígenas" ou "asiáticos". A origem dos ancestrais maternos e paternos foi indagada e foram classificados como "brancos" os indivíduos que afirmaram que os quatro avós eram descendentes de europeus. Aqueles indivíduos que eram capazes de referir na história dos ancestrais a miscigenação entre europeus e africanos, europeus e indígenas, indígenas e africanos ou entre indígenas, africanos e europeus foram considerados "pardos". Indivíduos com os quatro avós, maternos e 
paternos, com origem africana, foram classificados como "negros". Receberam classificação de "indígenas" os indivíduos cujos quatro avós eram descendentes de indígenas. Finalmente, aqueles com ancestrais japoneses ou chineses foram classificados como "asiáticos". Caso o indivíduo declarasse não conhecer a origem de seus ancestrais, a classificação foi baseada na aparência facial e cor da pele.

\section{2 - Metodologia}

\subsection{1 - Extração de DNA genômico e quantificação do DNA}

As amostras de sangue (aproximadamente $5 \mathrm{~mL}$ ) foram processadas e o DNA foi extraído, segundo o protocolo de rotina do Laboratório de Genética Humana, com fenol e clorofórmio (Sambrook e col, 1989). Parte das amostras foi extraída no aparelho Autopure $L S$ da Gentra Systems. Posteriormente, cada amostra de DNA foi quantificada com o auxílio dos aparelhos HITACHI - U-200 SPECTROPHOTOMETER ou NANODROP ND1000 (NanoDrop Technologies). Finalmente, uma alíquota foi diluída em água milli-Q autoclavada com a finalidade de obter novas amostras de DNA com concentração de 100 a $200 \mathrm{ng} / \mu \mathrm{L}$.

\subsection{2 - Estudo dos polimorfismos de DNA mitocondrial}

As estratégias empregadas para a determinação dos haplogrupos de DNA mitocondrial se basearam em PCR-RFLP (polimorfismo de comprimento de fragmentos de restrição), estudo da deleção de 9pb e sequenciamento da região hipervariável I do DNA mitocondrial (HVS-I).

\subsection{3 - Metodologias de PCR-RFLP e de estudo da deleção de 9pb}

Concentramo-nos inicialmente na identificação das linhagens L1 + L2 do macrohaplogrupo africano L por PCR-RFLP (com enzima Hpa I) (Chen e col, 2000), e do haplogrupo B, pela presença da deleção de 9pb (Hertzberg e col, 1989; Torroni e col, 1992). Para a identificação dos indivíduos pertencentes ao macro-haplogrupo L (L1+L2), amplificamos por PCR o segmento de interesse com os primers 5' TAC TAC AAC CCT TCG CTG AC 3' e 5' CTA GGG TGA CTT CAT ATG AG 3'. Este segmento está 
localizado no gene mitocondrial NDI e inclui a posição 3592 (Figura 1). Após a amplificação, as amostras foram submetidas à digestão com a enzima de restrição HpaI e os fragmentos resultantes da digestão foram analisados em gel de agarose a $2 \%$ corado com brometo de etídeo e exposto à luz UV. A presença de uma banda de 150 pb (correspondendo a dois fragmentos de $150 \mathrm{pb}$ ) indica que a digestão pela enzima ocorreu, portanto, a amostra pertence às linhagens africanas L1 ou L2 (Figura 7). Para a identificação do haplogrupo B, o segmento de DNA de interesse amplificado com os primers 5' TAC TAC AAC CCT TCG CTG AC 3' e 5' CTA GGG TGA CTT CAT ATG AG 3' foi submetido à reação da PCR. A deleção está localizada na região $\mathrm{V}$ do DNA mitocondrial, entre os genes da COII e RNAt ${ }^{\text {Lys }}$ (Figura 1). O produto da PCR foi submetido a uma eletroforese em gel de agarose a 3\% a fim de se detectar a deleção de 9 pb característica desse haplogrupo (Figura 8). A existência de algumas linhagens africanas com o sítio $H p a$ I e a deleção 9pb torna necessário o estudo de todas as amostras em relação à deleção e ao sítio de restrição para a enzima Hpa I na posição 3592. Apenas os indivíduos com a deleção de 9pb e sem o sítio de restrição para a enzima Hpa I 3592 são classificadas como pertencentes ao haplogrupo B.

Todos os 939 indivíduos da amostra foram submetidos aos dois testes.

\subsection{4 - Metodologia do sequenciamento da região hipervariável (HVS-I)}

Tanto as amostras já classificadas em haplogrupos com base nos dois testes citados acima como pertencentes ao Macro-Haplogrupo L (L1+L2) ou ao Haplogrupo B, como aquelas em que a classificação não foi possível somente com esses testes foram submetidas ao sequenciamento da HVS-I (Região Hipervariável I) (Figura 1). Em virtude do alto custo das reações, quando foi determinado um haplogrupo por sequenciamento, todos os indivíduos aparentados desse indivíduo pela linhagem materna foram considerados como pertencentes ao mesmo haplogrupo e excluídos do sequenciamento. Esta exclusão foi baseada nas genealogias das comunidades construídas pela equipe do Laboratório. Em outras palavras, um único indivíduo de cada "matrilinhagem" foi selecionado para sequenciamento.

Para o sequenciamento da (HVS-I), o segmento de DNA de interesse amplificado com os primers 5' TCA AAG AAC CCT ACA CCA GTC TTG TAA AAC C 3' e 5' CCT GAA 
GTA GGA ACC AGA TG 3' foi submetido à uma reação de PCR em duplicata. A purificação do produto da PCR foi feita por meio do "Illustra GFX PCR DNA and gel purification Kit" (GE healthcare), segundo instruções do fabricante. O produto purificado foi então submetido à reação de sequenciamento. Todos os indivíduos selecionados foram sequenciados com os primers Forward e Reverse. O sequenciamento automático foi realizado no aparelho MegaBACE ${ }^{\mathrm{TM}} 1000$ da Amersham Biosciences. O resultado do sequenciamento foi impresso e comparado base a base com a sequência padrão de Anderson e col (1981) entre as posições 16010 e 16498. Também foi alinhado com a sequência referência de Anderson e col. (1981) por meio do programa BioEdit (Hall, 1999). As posições das substituições encontradas foram registradas para cada amostra e o conjunto das substituições encontradas foi comparado com amostras da literatura (Torroni e col, 1993, 1996; Bandelt e col, 2001; Pereira e col, 2001; Salas e col, 2002, 2004; Mishmar e col, 2003; Kivisild e col, 2004; Rosa e col, 2004), o que nos permitiu classificá-las em um haplogrupo mitocondrial. Um exemplo está apresentado na Figura 9. Os resultados do sequenciamento da HVS-I foram analisados em colaboração com o grupo de pesquisa da Profa. Dra. Ândrea Kely Campos Ribeiro dos Santos do Laboratório de Genética Humana e Médica da Universidade Federal do Pará, que auxiliou na identificação dos haplogrupos.

Um total de 401 amostras foi submetido ao sequenciamento do DNA.

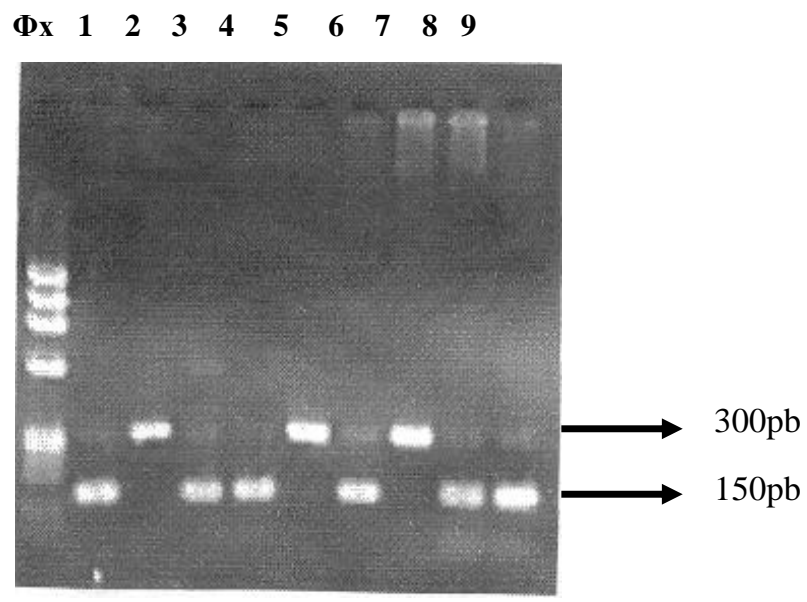

Figura 7 - Eletroforese em gel de agarose dos produtos da digestão com a enzima de restrição Hpa I, indicando os fragmentos em que a digestão não ocorreu (300pb) e os fragmentos em que a digestão ocorreu (150pb). O padrão de peso molecular utilizado foi o DNA do fago $\Phi \times 174$ digerido com a enzima de restrição Hae III. 


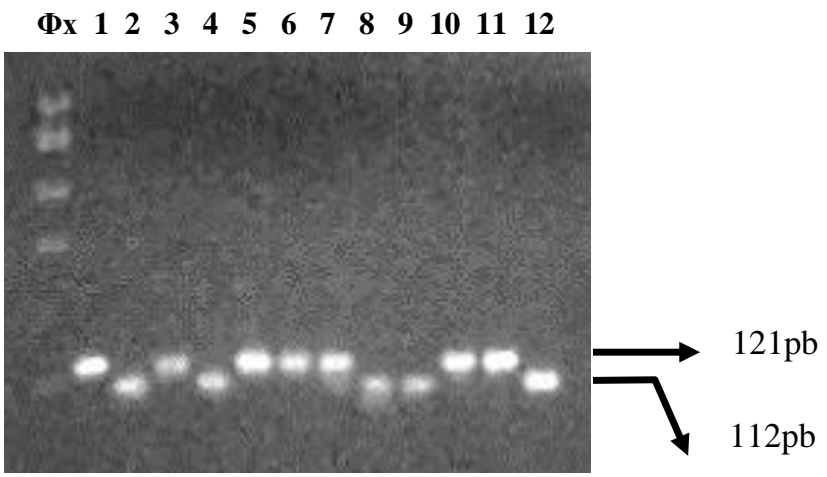

Figura 8 - Eletroforese em gel de agarose a 3\% dos produtos da amplificação da PCR, indicando fragmentos portadores da deleção (112pb) e fragmentos sem deleção (121pb). O padrão de peso molecular utilizado foi o DNA do fago $\Phi$ x174 digerido com a enzima de restrição Hae III.
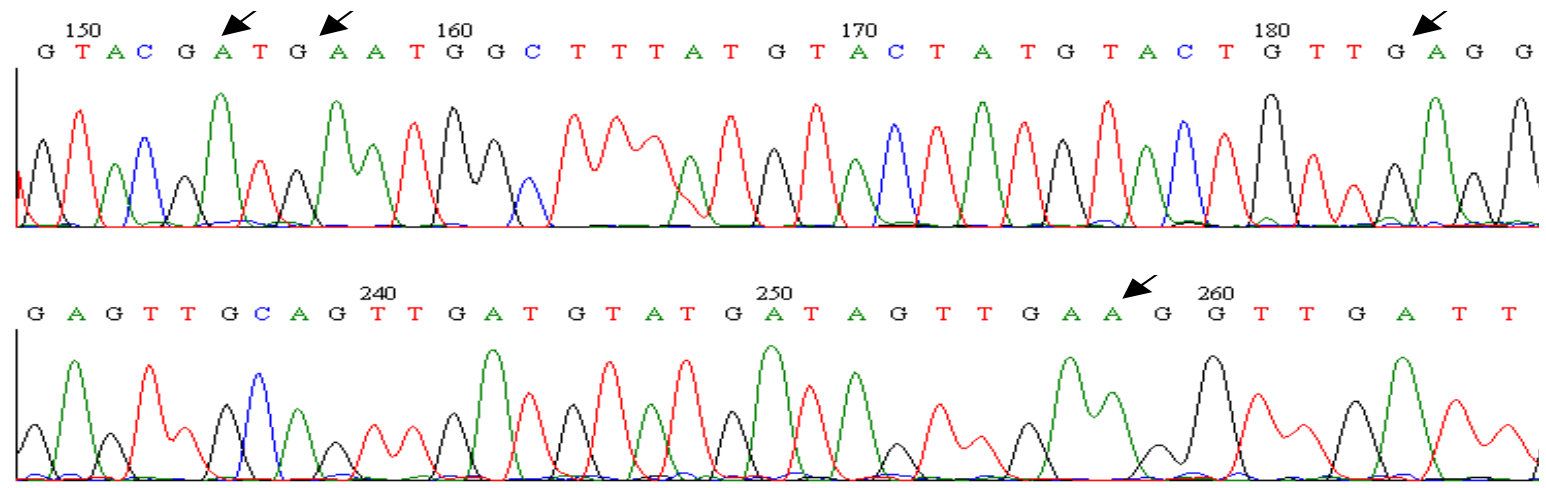

Figura 9 - Resultado do sequenciamento da região hipervariável do DNA mitocondrial (HVS-I) com o primer reverse. As setas indicam as posição das substituições encontradas neste indivíduo em relação à sequência de Anderson e col (1981) nas posições 16223, 16298, 16325, 16327, respectivamente, caracterizando uma linhagem mitocondrial pertencente ao Haplogrupo C, ameríndio.

\subsection{5 - Análise Estatística dos Resultados}

\subsubsection{1 - Mistura Interétnica}

Após a caracterização do haplogrupo de DNA mitocondrial de cada amostra e de seus parentes pela linhagem materna (por dedução), foi utilizado o método de contagem de indivíduos com cada haplogrupo para estimar a mistura interétnica em cada população. 


\subsubsection{2 - Redes de Haplótipos (Networks)}

Certos processos biológicos não são adequadamente representados por filogenias que somente representam ramificações e não representam uniões de taxas. Os processos de união ou agregação de taxas são denominados de eventos de reticulação. Filogenias que incorporam esse tipo de fenômeno são conhecidas como redes ou Networks. Os eventos de reticulação geram formações gráficas prismáticas ou loops.

A presença de reticulações pode ser devida a duas principais razões: (i) O fenômeno pode ser devido à presença de mutações fantasmas ou (ii) devido a ocorrência de eventos de homoplasia (mutações paralelas, mutações convergentes e mutações reversas). As mutações fantasmas ou polimorfismos virtuais são produzidos por erros durante a identificação das mutações ou por artefatos técnicos do sequenciamento.

Somente com uma cuidadosa análise das mutações envolvidas nas reticulações é possível descartar a possibilidade de ocorrência de mutações fantasmas.

As redes são empregadas quando homoplasias resultantes de mutações paralelas ou reversas são frequentes. Isto tipicamente ocorre com dados de sequenciamento da região controle do DNAmt e genotipagem de microssatélites, devido a sua elevada taxa de mutação.

Cada haplótipo e/ou haplogrupo com suas mutações correspondentes foi avaliado pelo método median joining por meio do programa Network v.4.1.0.9 (Bandelt e col, 1999). A construção das redes foi desenvolvida de duas formas: (i) por haplogruplo e (ii) pelo conjunto total das linhagens africanas e ameríndias, respectivamente.

\subsubsection{3 - Diversidade Genética}

A taxa de heterozigose média $(\mathrm{H})$ é a medida mais adequada para se estimar a variação genética dentro de uma população. Esta medida corresponde à média da proporção esperada de heterozigotos por locos, considerando-se todos os locos de uma determinada população. Entretanto, este conceito somente se aplica para organismos diplóides (Nei e col, 1987). A diversidade haplotípica (Hd) é a medida utilizada para quantificar a heterogeneidade de sistemas "haplóides", como os haplótipos associados ao DNAmt, e equivale à taxa de heterozigose média. 
Para se calcular a diversidade de sequências "haplóides", Nei e Jin (1989) propuseram que a variação do DNA, referida como diversidade nucleotídica, pode ser definida como o número médio de substituições nucleotídicas, por sítio, entre duas sequências, sobre o número de todos os pares nucleotídeos comparados. Calculamos a diversidade haplotípica (Hd) e a diversidade nucleotídica ( $\pi$ ) com o programa DNAsp V.4.10. (Rosas e col, 2003).

\subsubsection{4 - Diferença Par-a-Par (Pairwise Difference)}

A diferença par-a-par, baseada nas sequências da região HVS-I, foi calculada por meio dos programas DNAsp v4.10. (Rosas e col, 2003). De acordo com Rogers e Harpening (1992), esta análise permite observar sinais de declínio ou expansão populacional. Essa distribuição é obtida comparando-se todos os pares possíveis de alelos da amostragem em estudo e plotando em um gráfico os números de diferenças entre cada comparação de sequência realizada e a frequência com que esses números de diferenças nucleotídicas aparecem na amostragem. Com o gráfico é possível também identificar uma média dessa distribuição de diferenças, que corresponde a uma forma de medir a diversidade genética, uma vez que este valor pode ser considerado como uma estimativa da média da diversidade de sequências da amostra em estudo.

\subsubsection{5 - Distância Genética}

Estudos de distância genética permitem medir as similaridades e diferenças entre as populações. Foi utilizada a medida de distância $F s t$ para investigar variações intra e interpopulacionais (Wright, 1951; Nei, 1986). O índice Fst é uma medida utilizada para estudar a estrutura populacional, derivada do índice de fixação de Wright, que mede os desvios observados de heterozigotos em relação aos valores esperados em uma população em panmixia. É calculado com base em diferenças em frequências alélicas. Em sistemas "haplóides", como o DNA mitocondrial, um haplótipo pode ser tratado como um alelo. Nestes casos, os valores de Fst são calculados com base nas diferenças de frequências haplotípicas.

Os valores de Fst entre os diferentes pares de populações foram calculados por meio do programa Arlequin v2.0 (Schneider e col, 2000), com as frequências haplotípicas obtidas a 
partir dos resultados de sequenciamento da região HVS-I. Estes cálculos resultaram em matrizes de valores de Fst. As matrizes também incluíram informações sobre frequências haplotípicas de populações selecionadas da literatura.

Os dados de $F s t$, por sua vez, foram empregados na construção de árvores filogenéticas, por meio do programa MEGA v.3.0 (Kumar e col, 2004) e baseado no método Neighbor Joining (Saitou e Nei, 1987), para que representássemos graficamente as relações entre as doze populações de quilombos do Vale do Ribeira, a amostragem da cidade de São Paulo e as comparações entre essas populações e populações de referência da literatura.

Como representantes de populações africanas foram selecionadas amostras dos Bantos (Silva Jr. e col, 2006; Quintana-Murci e col, 2008), uma vez que dados históricos e genéticos indicam que essas são as populações parentais mais prováveis dos escravos que chegaram a região do Vale do Ribeira. Como representantes dos europeus selecionamos amostras de origem portuguesa (Pereira e col, 2000) e como representantes de ameríndios foram selecionadas amostras de origem Guarani e Kaigang, importantes grupos indígenas habitantes das regiões sudeste e sul do Brasil (Marrero e col, 2007). Foram também selecionadas amostras representantes de afro-brasileiros (Bortolini e col, 1999; Ribeiro-dosSantos e col, 2002, 2007; Silva Jr. e col, 2006; Hünemeier e col, 2007), brasileiros brancos (Alves-Silva e col, 2000; Marrero e col, 2005) e populações africanas banto (Silva Jr. e col, 2006; Quintana-Murci e col, 2008). 


\section{4 - RESULTADOS}




\section{4 - Resultados}

Foram investigadas um total de 939 amostras de doze comunidades remanescentes de quilombos do Vale do Ribeira (São Pedro, Galvão, Pedro Cubas, Pilões, André Lópes, Maria Rosa, Abobral Margem Direita (Abobral D), Abobral Margem Esquerda (Abobral ME), Ivaporunduva, Sapatu, Nhungara e Poça) com a técnica de PCR-RFLP e estudo da deleção de 9pb para definição de haplogrupos. Desse total, 401 amostras foram selecionadas e submetidas ao sequenciamento da HVS-I.

Os dados de sequenciamento da HVS-I das doze comunidades formaram um conjunto de dados de haplótipos de indivíduos não aparentados (401 amostras). Este conjunto de dados, representativo das diferentes matrilinhagens, foi utilizado para as análises de redes de haplótipos, estimativas de diversidade genética e análises de distância genética. $\mathrm{O}$ total de 939 amostras, com indivíduos aparentados, foi utilizado nas estimativas de frequência e mistura interétnica dos haplogrupos mitocondriais

\section{1 - Frequência dos Haplogrupos Mitocondriais e Mistura Interétnica}

Os resultados da classificação dos haplogrupos mitocondriais para o total de 939 amostras, em cada uma das comunidades de quilombos do Vale do Ribeira, encontram-se na Tabela II. Esta tabela inclui todos os indivíduos pertencentes a uma mesma matrilinhagem, mesmo os que foram submetidos ao sequenciamento. Seus haplogrupos foram determinados por dedução, com o auxílio das genealogias. A Tabela II também apresenta as frequências dos haplogrupos e os resultados globais de estimativa de mistura interétnica, respectivamente, na amostra da cidade de São Paulo.

Os resultados da descrição dos haplótipos e nucleotídeos variáveis de sequências da região hipervariável I do DNA mitocondrial em associação com resultados da análise de RFLPs (presença do sítio polimórfico para Hpa I - 3.592 e presença da deleção de 9pb) e a origem geográfica, observados em 401 indivíduos não aparentados selecionados das doze comunidades de quilombos do Vale do Ribeira, encontram-se na Tabela III. Na Tabela IV estão apresentados os resultados referentes às amostras da cidade de São Paulo. 
Os resultados obtidos no total das comunidades remanescentes de quilombos indicam alta frequência de DNA mitocondrial ameríndio (49,3\%) e africano (49,2\%) para todas as doze comunidades investigadas, além da frequência reduzida de haplogrupos europeus $(1,5 \%)$ (Tabela II).

Na fração de haplótipos ameríndios das 12 comunidades afro-descendentes, as linhagens mais frequentemente encontradas pertencem ao haplogrupo B (29\%), seguidas das linhagens do haplogrupo A (9\%), do haplogrupo C $(8 \%)$ e do menos frequente, o haplogrupo D (4\%). Em relação à fração africana, os afro-descendentes do Vale do Ribeira revelaram predomínio de linhagens do Macro-Haplogrupo L (L1 + L2) com uma frequência de 37\%, seguida das linhagens do haplogrupo L3 (13\%). O conjunto dos haplogrupos europeus ( $\mathrm{H}, \mathrm{J}, \mathrm{K}$ e T) atingiu uma frequência de 1,5\% (Tabela II).

Em São Paulo, a fração européia foi de 16\%, os ameríndios e africanos surgiram na proporção de $34 \%$ e $50 \%$ respectivamente. A fração ameríndia revelou como linhagem mais frequente o haplogrupo B (12\%), seguido dos haplogrupos C e A (ambos com 9\%) e, finalmente, o menos frequente, haplogrupo D (4\%). A fração africana, da mesma forma que nos afro-descendentes do Vale do Ribeira, apresentou o Macro-Haplogrupo L (L1 + L2) como mais frequente (26\%), seguido do haplogrupo L3 (19\%). Entretanto, foi detectado o haplogrupo L0 (5\%), ausente nos afro-descendentes do Vale do Ribeira (Figura 10).

A amostra de indivíduos da cidade de São Paulo apresentou um panorama distinto das comunidades de quilombos. Apesar de ambos conjuntos amostrais revelarem uma presença significativa de linhagens africanas (aproximadamente 50\%), os resultados globais obtidos apontam para uma participação reduzida de haplogrupos ameríndios no pool gênico dos paulistas (total de 34\%) e presença mais frequente de linhagens européias (16\%) (Tabela II).

Em relação à presença de DNAmt de origem européia, o haplogrupo V foi observado somente em São Paulo. Em contrapartida, o haplogrupo J, identificado nos afrodescendentes do Vale do Ribeira, esteve ausente em São Paulo.

A investigação por sequenciamento direto da HVS-I na fração ameríndia nos quilombos ocorreu em 192 amostras, revelando 27 haplótipos diferentes. Em relação à fração africana, o sequenciamento foi feito em 197 amostras, revelando 53 haplótipos distintos. A reduzida 
presença européia foi detectada em 9 amostras, revelando 6 haplótipos distintos (Tabela III).

A investigação do sequenciamento em São Paulo ocorreu nas 104 amostras e revelou 68 haplótipos distintos. Do total de haplótipos identificados em São Paulo, 52\% são compartilhados com os remanescentes de quilombos do Vale do Ribeira (ver Tabela IV, onde os haplótipos exclusivos de São Paulo aparecem em vermelho). 
Tabela II - Resultados da determinação dos haplogrupos mitocondriais nas 12 comunidades remanescentes de quilombos do Vale do Ribeira. Na coluna "Populações" estão indicadas as 12 comunidades analisadas, o número de vezes e a frequência em porcentagem que um determinado haplogrupo foi identificado. Esta tabela inclui os indivíduos que não foram diretamente sequenciados e que tiveram seus haplogrupos determinados por dedução. A nomenclatura das populações corresponde a: AN (André Lópes), GA (Galvão), MR (Maria Rosa), PC (Pedro Cubas), PS (Pilões), SP (São Pedro), TU (Sapatu), DR (Abobral Margem Direita), AB (Abobral Margem Esquerda), IV (Ivaporunduva), NH (Nhunguara) e PA (Poça).

\begin{tabular}{|c|c|c|c|c|c|c|c|c|c|c|c|c|c|c|}
\hline \multicolumn{15}{|c|}{ Populações } \\
\hline Haplogrupos & GA & SP & PS & MR & DR & $\mathbf{A B}$ & IV & PA & TU & NH & $\mathbf{A N}$ & $\mathbf{P C}$ & Total Quilombos & São Paulo \\
\hline Haplogrupo A & $5(9 \%)$ & $15(23 \%)$ & $5(10 \%)$ & 0 & $1(2 \%)$ & $7(7 \%)$ & $19(14 \%)$ & 0 & $7(7 \%)$ & $17(14 \%)$ & $6(5 \%)$ & $7(7 \%)$ & $89(9 \%)$ & $10(9 \%)$ \\
\hline Haplogrupo B & $28(48 \%)$ & $32(49 \%)$ & $7(14 \%)$ & $5(26 \%)$ & $7(17 \%)$ & $29(29 \%)$ & $55(41 \%)$ & $4(8 \%)$ & $28(29 \%)$ & $25(20 \%)$ & $25(23 \%)$ & $24(24 \%)$ & $269(29 \%)$ & $12(12 \%)$ \\
\hline Hsplogrupo C & $12(21 \%)$ & $2(3 \%)$ & $5(10 \%)$ & $4(21 \%)$ & $3(7 \%)$ & $4(4 \%)$ & $5(4 \%)$ & $2(4 \%)$ & 0 & $7(6 \%)$ & $10(9 \%)$ & $18(18 \%)$ & $72(8 \%)$ & $10(9 \%)$ \\
\hline Haplogrupo D & 0 & 0 & 0 & 0 & 0 & 0 & $10(8 \%)$ & $7(14 \%)$ & $12(13 \%)$ & 0 & $3(3 \%)$ & $1(1 \%)$ & $33(4 \%)$ & $4(4 \%)$ \\
\hline Total Ameríndios & $45(78 \%)$ & $49(75 \%)$ & $17(35 \%)$ & $9(47 \%)$ & $11(27 \%)$ & $40(40 \%)$ & $89(67 \%)$ & $13(26 \%)$ & $47(50 \%)$ & $49(40 \%)$ & $44(41 \%)$ & $50(50 \%)$ & $463(49,3 \%)$ & $36(34 \%)$ \\
\hline Haplogrupo L0 & 0 & 0 & 0 & 0 & 0 & 0 & 0 & 0 & 0 & 0 & 0 & 0 & 0 & $5(5 \%)$ \\
\hline Haplogrupo L1c & $13(22 \%)$ & $3(5 \%)$ & $1(2 \%)$ & $3(16 \%)$ & $17(41 \%)$ & $33(33 \%)$ & $18(17 \%)$ & $4(8 \%)$ & $13(14 \%)$ & $15(12 \%)$ & $32(29 \%)$ & $28(28 \%)$ & $180(19 \%)$ & $6(6 \%)$ \\
\hline Haplogrupo L1b & 0 & $10(15 \%)$ & $3(6 \%)$ & $2(11 \%)$ & $5(12 \%)$ & $8(8 \%)$ & $6(5 \%)$ & $12(25 \%)$ & 0 & $19(15 \%)$ & $6(5 \%)$ & 0 & $71(8 \%)$ & $2(2 \%)$ \\
\hline Haplogrupo L2 & 0 & $2(3 \%)$ & $18(37 \%)$ & $5(26 \%)$ & $7(17 \%)$ & $6(6 \%)$ & $1(1 \%)$ & $1(2 \%)$ & $13(14 \%)$ & $20(16 \%)$ & $7(6 \%)$ & $11(11 \%)$ & $91(10 \%)$ & $19(18 \%)$ \\
\hline Haplogrupo L3 & 0 & $1(2 \%)$ & $10(20 \%)$ & 0 & $1(2 \%)$ & $13(13 \%)$ & $16(12 \%)$ & $14(29 \%)$ & $17(18 \%)$ & $20(16 \%)$ & $17(15 \%)$ & $11(11 \%)$ & $120(13 \%)$ & $20(19 \%)$ \\
\hline Total Africanos & $13(22 \%)$ & $16(25 \%)$ & $32(65 \%)$ & $10(53 \%)$ & $30(73 \%)$ & $60(60 \%)$ & $41(31 \%)$ & $31(63 \%)$ & $43(45 \%)$ & $74(60 \%)$ & $62(58 \%)$ & $50(50 \%)$ & $462(49,2 \%)$ & $52(50 \%)$ \\
\hline Haplogrupo H & 0 & 0 & 0 & 0 & 0 & 0 & $3(2 \%)$ & $4(8 \%)$ & 0 & 0 & 0 & 0 & $7(0,7 \%)$ & $10(10 \%)$ \\
\hline Haplogrupo J & 0 & 0 & 0 & 0 & 0 & 0 & 0 & $1(2 \%)$ & $4(4 \%)$ & 0 & 0 & 0 & $5(0,5 \%)$ & 0 \\
\hline Haplogrupo K & 0 & 0 & 0 & 0 & 0 & 0 & 0 & 0 & 0 & 0 & $1(1 \%)$ & 0 & $1(0,1 \%)$ & $1(1 \%)$ \\
\hline Haplogrupo T & 0 & 0 & 0 & 0 & 0 & 0 & 0 & 0 & $1(1 \%)$ & 0 & 0 & 0 & $1(0,1 \%)$ & $4(4 \%)$ \\
\hline Haplogrupo V & 0 & 0 & 0 & 0 & 0 & 0 & 0 & 0 & 0 & 0 & 0 & 0 & 0 & $1(1 \%)$ \\
\hline Total Europeus & $\mathbf{0}$ & $\mathbf{0}$ & $\mathbf{0}$ & $\mathbf{0}$ & $\mathbf{0}$ & $\mathbf{0}$ & $3(2 \%)$ & $5(10 \%)$ & $5(5 \%)$ & $\mathbf{0}$ & $1(1 \%)$ & $\mathbf{0}$ & $14(1,5 \%)$ & $16(16 \%)$ \\
\hline Indeterminadoss & $\mathbf{0}$ & $\mathbf{0}$ & $\mathbf{0}$ & $\mathbf{0}$ & $\mathbf{0}$ & $\mathbf{0}$ & $\mathbf{0}$ & $\mathbf{0}$ & $\mathbf{0}$ & $\mathbf{0}$ & $3(3 \%)$ & $\mathbf{0}$ & $3(0,3 \%)$ & $\mathbf{0}$ \\
\hline Total & 58 & 65 & 49 & 19 & 41 & 100 & 133 & 49 & 95 & 123 & 107 & 100 & 939 & 104 \\
\hline
\end{tabular}


Tabela III - Resultados da análise molecular do DNA mitocondrial (HVS-I) das 12 comunidades remanescentes de quilombos do Vale do Ribeira. Os números na coluna "Nucleotídeos variáveis HVS-I" indicam os nucleotídeos que diferem da sequência de referência de Anderson e col. (1981), 16000 deve ser adicionado aos números apresentados para se obter a exata posição nucleotídica na molécula de DNA mitocondrial. Os haplótipos foram nomeados (coluna Haplótipo) para facilitar a discussão posterior. Na coluna "Outros polimorfismos" a deleção de 9pb (Del9pb) foi indicada apenas nas amostras em que ela esteve presente. Na coluna "População" estão indicadas as 12 comunidades analisadas e o número de vezes que um determinado haplótipo foi identificado. A nomenclatura das populações corresponde: AN (André Lópes), GA (Galvão), MR (Maria Rosa), PC (Pedro Cubas), PS (Pilões), SP (São Pedro), TU (Sapatu), DR (Abobral Margem Direita), AB (Abobral Margem Esquerda), IV (Ivaporunduva), NH (Nhunguara) e PA (Poça).

\begin{tabular}{|c|c|c|c|c|c|c|c|c|c|c|c|c|c|c|c|c|}
\hline \multirow[t]{2}{*}{ Haplótipo } & \multicolumn{12}{|c|}{ Populações } & \multirow[b]{2}{*}{ Nucleotídeos Variáveis HVS-I } & \multirow{2}{*}{$\begin{array}{c}\text { Origem } \\
\text { Étnica }\end{array}$} & \multirow[b]{2}{*}{ Haplogrupo } & \multirow[t]{2}{*}{$\begin{array}{c}\text { Outros } \\
\text { Polimorfismos }\end{array}$} \\
\hline & AN & GA & MR & $\mathrm{PC}$ & PS & SP & TU & DR & $\mathrm{AB}$ & IV & NH & PA & & & & \\
\hline HP01 & & & & & & 1 & & & & & & & $111,126,223,259,266,290,319,327,362$ & Ameríndio & A & $(-) 3,592$ \\
\hline HP02 & 2 & & & & 1 & & 1 & & 4 & 2 & 6 & & $092,111,223,290,319,362$ & Ameríndio & A & $(-) 3,592$ \\
\hline HP03 & & & & & 1 & & & & & & & & $111,185,290,310,319,362$ & Ameríndio & A & $(-) 3,592$ \\
\hline HP04 & & 2 & & 1 & & 4 & & & & & 1 & & $111,126,223,278,290,319,362$ & Ameríndio & A & $(-) 3,592$ \\
\hline HP05 & & & & & & & & & & 1 & & & $111,218,223,239,266,290,319,362$ & Ameríndio & A & $(-) 3,592$ \\
\hline HP06 & & & & & & & & & & 1 & & & $111,223,290,319,362$ & Ameríndio & A & $(-) 3,592$ \\
\hline Total & 2 & 2 & & 1 & 2 & 5 & 1 & & 4 & 4 & 7 & & & & & \\
\hline Total A & 6 hap & plótip & $\mathrm{os} / 2 \varepsilon$ & $8 \mathrm{seq}$ & uênc & & & & & & & & & & & \\
\hline HP07 & & & & & & & 1 & & & & & & $179,180,189,217,241$ & Ameríndio & B & Del9pb, (-)3,592 \\
\hline HP08 & & & & 3 & 1 & & 2 & & & 1 & 6 & & $189,217,241$ & Ameríndio & $\mathrm{B}$ & Del9pb, (-)3,592 \\
\hline HP09 & 4 & 1 & 1 & 7 & 4 & 2 & 7 & 2 & & 2 & & 2 & 189,217 & Ameríndio & $\mathrm{B}$ & Del9pb, (-)3,592 \\
\hline HP10 & & & & & & & 1 & & & & & & $111,189,217,241,311$ & Ameríndio & B & Del9pb, (-)3,592 \\
\hline HP11 & & 1 & & & & & & & & & & & $189,217,240,311$ & Ameríndio & B & Del9pb, (-)3,592 \\
\hline HP12 & 6 & 15 & 2 & 5 & 1 & 11 & 2 & 3 & 9 & 11 & 8 & & $189,217,311$ & Ameríndio & B & Del9pb, (-)3,592 \\
\hline HP13 & & & & & & & & & & & & 1 & $189,217,223,311$ & Ameríndio & $\mathrm{B}$ & Del9pb, (-)3,592 \\
\hline Total & 10 & 17 & 3 & 15 & 6 & 13 & 13 & 5 & 9 & 14 & 14 & 3 & & & & \\
\hline Total B & 7 hap & plótip & $\mathrm{os} / 12$ & $22 \mathrm{se}$ & quên & cias & & & & & & & & & & \\
\hline HP14 & 5 & 1 & & & & & & 2 & 1 & & 3 & & $051,172,223,295,298,311,325,327,335$ & Ameríndio & $\mathrm{C}$ & $(-) 3,592$ \\
\hline HP15 & & & & 2 & & & & & 1 & & & & $051,184,223,287,298,311,325,327$ & Ameríndio & $\mathrm{C}$ & $(-) 3,592$ \\
\hline HP16 & 1 & 2 & & 1 & & 1 & & & & 1 & 1 & & $093,209,223,234,298,325,327$ & Ameríndio & $\mathrm{C}$ & $(-) 3,592$ \\
\hline HP17 & & & & & & & & & & & & 1 & $093,223,234,298,325,327$ & Ameríndio & $\mathrm{C}$ & $(-) 3,592$ \\
\hline HP18 & & & & 1 & & & & & & & & & $093,209,223,234,278,298,325,327,387$ & Ameríndio & $\mathrm{C}$ & $(-) 3,592$ \\
\hline
\end{tabular}


Tabela III - Continuação.

\begin{tabular}{|c|c|c|c|c|c|c|c|c|c|c|c|c|c|c|c|c|}
\hline \multirow[t]{2}{*}{ Haplótipo } & \multicolumn{12}{|c|}{ Populações } & \multirow[b]{2}{*}{ Nucleotídeos Variáveis HVS-I } & \multirow{2}{*}{$\begin{array}{c}\text { Origem } \\
\text { Étnica }\end{array}$} & \multirow[b]{2}{*}{ Haplogrupo } & \multirow[t]{2}{*}{ Outros Polimorfismos } \\
\hline & AN & GA & MR & $\mathrm{PC}$ & PS & SP & \begin{tabular}{|l|l|}
$\mathrm{TU}$ \\
\end{tabular} & DR & $\mathrm{AB}$ & IV & \begin{tabular}{|l|l|l|l|l|l}
$\mathrm{NH}$ \\
\end{tabular} & $\mathrm{PA}$ & & & & \\
\hline HP43 & & & & & & & & & & & 1 & & $129,187,189,223,265,278,286,292,294,311,360$ & Africano & L1c & $(+) 3,592$ \\
\hline HP44 & & & & & & & 1 & & & & & & $129,187,189,223,265,274,278,293,294,311,360,368$ & Africano & L1c1 & $(+) 3,592$ \\
\hline HP45 & & & & & & & 1 & & & & & & $172,187,189,219,223,278,293,294,311,360,362,399$ & Africano & L1c1 & $(+) 3,592$ \\
\hline HP46 & & & & & & 2 & & & & & & & $114 \mathrm{G}, 126,187,189,223,264,270,274,278,293,311$ & Africano & L1b1 & Del9pb, $(+) 3,592$ \\
\hline HP47 & 2 & & & & & & & 1 & 1 & 3 & 4 & & $114 \mathrm{G}, 126,187,189,223,264,270,274,278,293,311$ & Africano & L1b1 & $(+) 3,592$ \\
\hline HP48 & & & & & & & & & & & 1 & & $114 \mathrm{~A}, 126,187,189,192,223,256,264,270,278,294,311$ & Africano & L1b & $(+) 3,592$ \\
\hline HP49 & & & & & & & & & & & 1 & & $189,190,223,264,270,274,278,293,294,311$ & Africano & L1b & $(+) 3,592$ \\
\hline HP50 & & & 1 & & & & & & & & & 3 & $126,187,189,223,264,270,278,293,311$ & Africano & L1b1 & $(+) 3,592$ \\
\hline HP51 & & & & & & & & & & & & 1 & $126,187,189,223,264,270,274,278,293,311$ & Africano & L1b1 & $(+) 3,592$ \\
\hline HP52 & & & & & & & & 1 & & 1 & & & $126,187,189,223,264,270,278,311$ & Africano & L1b & $(+) 3,592$ \\
\hline Total & 13 & 8 & 1 & 12 & 1 & 4 & 5 & 5 & 19 & 8 & 11 & 7 & & & & \\
\hline Total L1 & \multicolumn{16}{|c|}{24 haplótipos / 97 sequências } \\
\hline HP53 & & & & & & & & & & & 1 & & $187,223,234,256,278,294,295,311,390$ & Africano & L2a1 & $(+) 3,592$ \\
\hline HP54 & & & & 1 & & & & & & & & & $093,129,189,278,294,311,354,390,399$ & Africano & $\mathrm{L} 2 \mathrm{~d} 1$ & $(+) 3,592$ \\
\hline HP55 & & & & & & 1 & & 1 & & & & & $093,129,189,278,311,354,390$ & Africano & L2d1 & $(+) 3,592$ \\
\hline HP56 & & & & 4 & 8 & & 5 & & & & 2 & & $093,129,189,278,311,354,390,399$ & Africano & L2d1 & $(+) 3,592$ \\
\hline HP57 & 1 & & & & & & & & & & & & $093,223,234,249,256,278,294,295,309,390$ & Africano & L2a1 & $(+) 3,592$ \\
\hline HP58 & & & & & & & 1 & & & & & & $104,223,278,294,309,390$ & Africano & L2a1 & $(+) 3,592$ \\
\hline HP59 & & & & & 1 & & & & & & & & $114 \mathrm{~A}, 129,213,223,278,311,362,390$ & Africano & L2b1 & $(+) 3,592$ \\
\hline HP60 & & & & & 2 & & & & & & & & 114A, 192, 129, 213, 223, 278, 355, 356, 362, 390 & Africano & L2b1 & $(+) 3,592$ \\
\hline HP61 & & & & & & & & 1 & & & & & 114A, 192, 129, 213, 223, 278, 355, 362, 390 & Africano & L2b1 & $(+) 3,592$ \\
\hline HP62 & & & & & & & & & & & & 1 & $189,192,223,274,278,294,309,362,370,390$ & Africano & L2a1 & $(+) 3,592$ \\
\hline HP63 & & & & & & 1 & & & & & & & $189,223,278,294,309,390$ & Africano & L2a1a & $(+) 3,592$ \\
\hline HP64 & 2 & & 2 & & & & 1 & & 1 & 1 & 6 & & $223,234,249,256,278,294,295,390$ & Africano & L2a1f & $(+) 3,592$ \\
\hline HP65 & & & 3 & 1 & 1 & & & & & & & & $223,278,294,309,368,390$ & Africano & L2a1a & $(+) 3,592$ \\
\hline Total & 3 & & 5 & 6 & 12 & 2 & 7 & 2 & 1 & 1 & 9 & 1 & & & & \\
\hline Total L2 & \multicolumn{16}{|c|}{13 haplótipos / 49 sequências } \\
\hline HP66 & & & & & & & & & & & & 1 & $223,265 \mathrm{~T}, 311,320$ & Africano & L3e2 & $(-) 3,592$ \\
\hline HP67 & & & & & & & & & & & & 1 & $093,124,148,223,265 \mathrm{~T}, 319$ & Africano & L3d1 & $(-) 3,592$ \\
\hline HP68 & & & & & & & 1 & & & & & & $124,223,319$ & Africano & L3d1 & $(-) 3,592$ \\
\hline
\end{tabular}


Tabela III - Continuação.

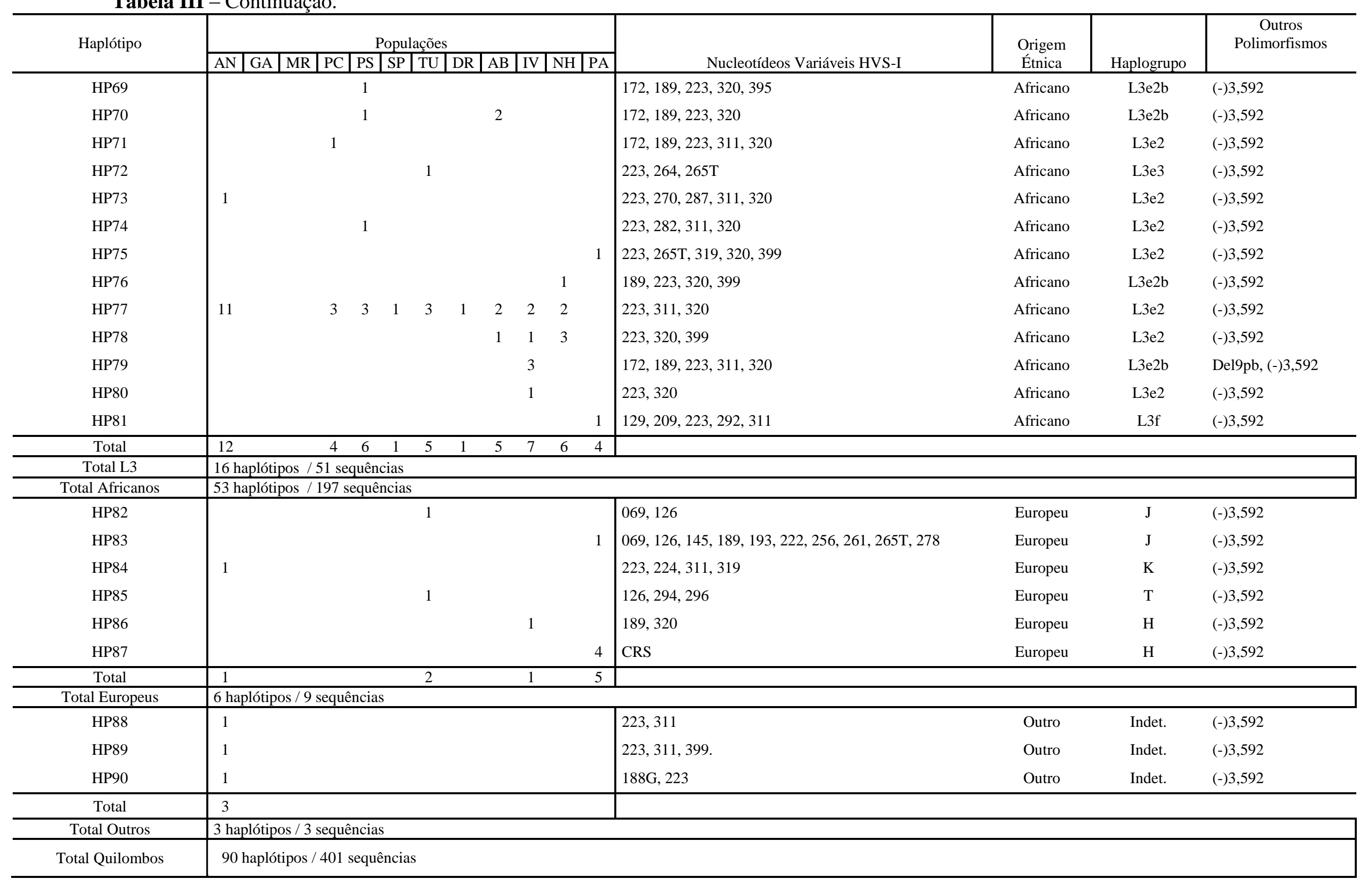


Tabela IV - Resultados das análises moleculares do DNA mitocondrial, referentes a amostra de indivíduos da cidade de São Paulo. Os números na coluna "Nucleotídeos variáveis HVS-I" indicam os nucleotídeos que diferem da seqüência de referência de Anderson e col. (1981), o número 16000 deve ser adicionado aos números apresentados para se obter a exata posição nucleotídica na molécula de DNA mitocondrial. Na coluna "Outros polimorfismos" a deleção de 9pb (De19pb) foi indicada apenas nas amostras em que ela esteve presente. Em vermelho foram indicados os haplótipos exclusivos de São Paulo, não detectados nos remanescentes de quilombos do Vale do Ribeira.

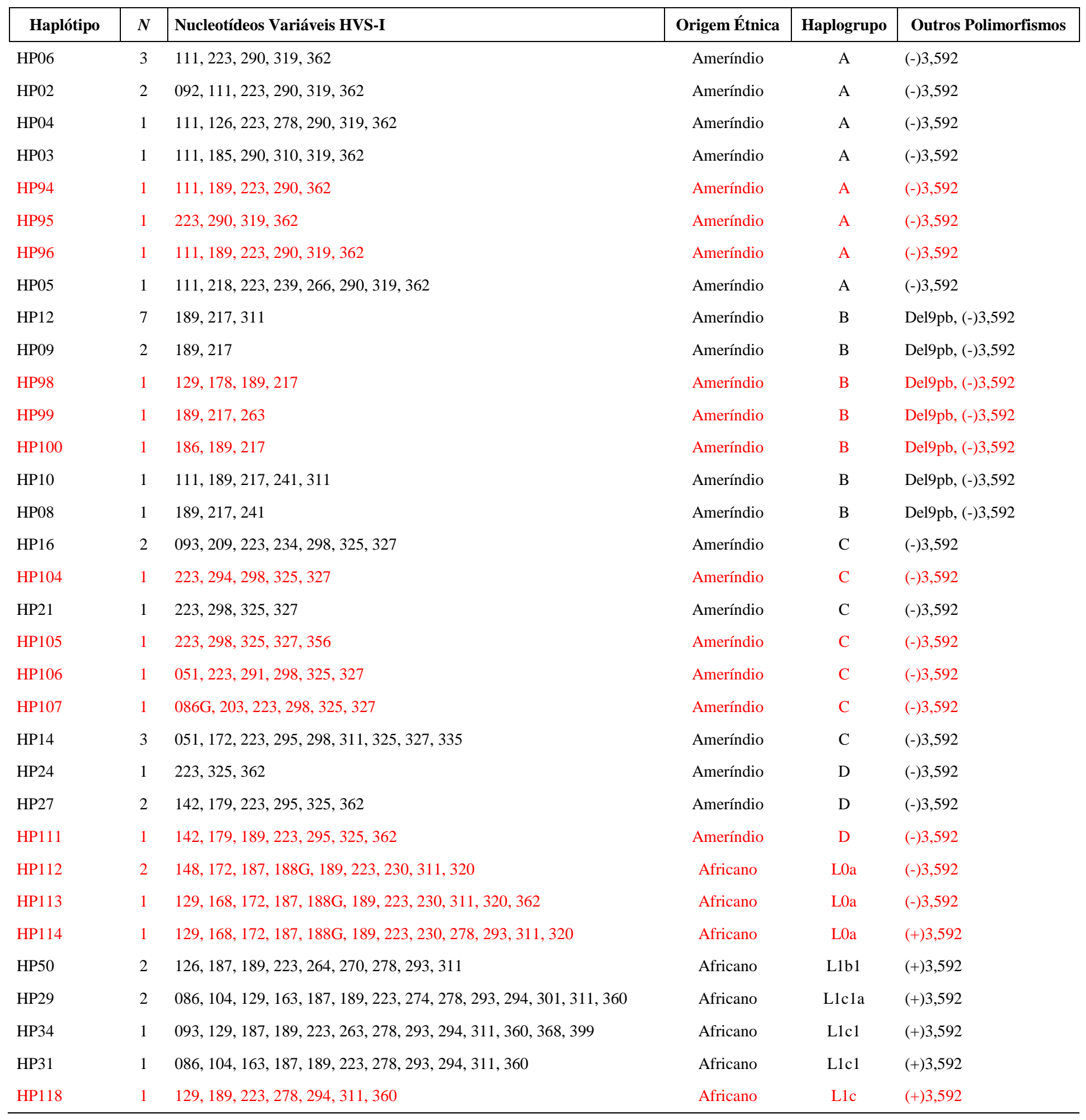


Tabela IV - Continuação.

\begin{tabular}{|c|c|c|c|c|c|}
\hline Haplótipo & $N$ & Nucleotídeos Variáveis HVS-I & Origem Étnica & Haplogrupo & Outros Polimorfismos \\
\hline HP119 & 1 & $129,189,192,223,278,294,309,390$ & Africano & L2a1 & $(+) 3,592$ \\
\hline HP63 & 8 & $189,223,278,294,309,390$ & Africano & L2a1a & $(+) 3,592$ \\
\hline HP64 & 1 & $223,234,249,256,278,294,295,390$ & Africano & L2a1f & $(+) 3,592$ \\
\hline HP56 & 2 & $093,129,189,278,311,354,390,399$ & Africano & $\mathrm{L} 2 \mathrm{~d} 1$ & $(+) 3,592$ \\
\hline HP53 & 1 & $187,223,234,256,278,294,295,311,390$ & Africano & L2a1 & $(+) 3,592$ \\
\hline HP59 & 1 & $114 \mathrm{~A}, 129,213,223,278,311,362,390$ & Africano & $\mathrm{L} 2 \mathrm{~b} 1$ & $(+) 3,592$ \\
\hline HP60 & 1 & $114 \mathrm{~A}, 192,129,213,223,278,355,356,362,390$ & Africano & $\mathrm{L} 2 \mathrm{~b} 1$ & $(+) 3,592$ \\
\hline HP125 & 4 & $129,209,223,292,295,311$ & Africano & L3f & $(-) 3,592$ \\
\hline HP126 & 1 & $124,223,278,311,362$ & Africano & $\mathrm{L} 3 \mathrm{~b} 2$ & $(-) 3,592$ \\
\hline HP80 & 1 & 223,320 & Africano & $\mathrm{L} 3 \mathrm{e} 2$ & $(+) 3,592$ \\
\hline HP81 & 1 & $129,209,223.292 .311$ & Africano & L3f & $(-) 3,592$ \\
\hline HP72 & 1 & $223,264,265 \mathrm{~T}$ & Africano & L3e3 & $(-) 3,592$ \\
\hline HP129 & 1 & 223,327 & Africano & $\mathrm{L} 3 \mathrm{e} 1$ & $(-) 3,592$ \\
\hline HP130 & 2 & $185,209,223,311,327$ & Africano & L3e1a & $(-) 3,592$ \\
\hline HP77 & 1 & $223,311,320$ & Africano & $\mathrm{L} 3 \mathrm{e} 2$ & $(-) 3,592$ \\
\hline HP132 & 1 & $129,223,256 \mathrm{~A}, 258,311,362$ & Africano & $\mathrm{L} 3 \mathrm{~h}$ & $(-) 3,592$ \\
\hline HP75 & 1 & $223,265 \mathrm{~T}, 319,320,399$ & Africano & $\mathrm{L} 3 \mathrm{e} 2$ & $(-) 3,592$ \\
\hline HP134 & 1 & $124,189,223,278,304,311,362$ & Africano & $\mathrm{L} 3 \mathrm{~b} 2$ & $(-) 3,592$ \\
\hline HP135 & 1 & $209,223,311$ & Africano & L3f & $(-) 3,592$ \\
\hline HP79 & 1 & $172,189,223,311,320$ & Africano & $\mathrm{L} 3 \mathrm{e} 2 \mathrm{~b}$ & Del9pb, (-)3,592 \\
\hline HP70 & 1 & $172,189,223,320$ & Africano & $\mathrm{L} 3 \mathrm{e} 2 \mathrm{~b}$ & $(-) 3,592$ \\
\hline HP137 & 1 & $124,189,223,278,304,311$ & Africano & $\mathrm{L} 3 \mathrm{~d} 3$ & $(-) 3,592$ \\
\hline HP138 & 2 & $185,223,327$ & Africano & L3e1 & $(-) 3,592$ \\
\hline HP139 & 1 & $189,223,265 \mathrm{~T}$ & Africano & L3e3 & $(-) 3,592$ \\
\hline HP140 & 1 & $111,126,223,259,290,319,362,390$ & Africano & $\mathrm{L} 3 \mathrm{~h}$ & $(-) 3,592$ \\
\hline HP87 & 8 & CRS & Europeu & $\mathrm{H}$ & $(-) 3,592$ \\
\hline HP86 & 1 & 189,320 & Europeu & $\mathrm{H}$ & $(-) 3,592$ \\
\hline HP141 & 1 & $263,296,355$ & Europeu & $\mathrm{H}$ & $(-) 3,592$ \\
\hline HP86 & 1 & 189,320 & Europeu & $\mathrm{H}$ & $(-) 3,592$ \\
\hline HP143 & 1 & 191 & Europeu & $\mathrm{H}$ & $(-) 3,592$ \\
\hline HP85 & 1 & $126,294,296,304$ & Europeu & $\mathrm{T}$ & $(-) 3,592$ \\
\hline HP145 & 1 & $126,292,294,399$ & Europeu & $\mathrm{T}$ & $(-) 3,592$ \\
\hline HP146 & 1 & $126,247,292,294,296,304$ & Europeu & $\mathrm{T}$ & $(-) 3,592$ \\
\hline HP147 & 1 & $126,163,186,189,292,294$ & Europeu & $\mathrm{T}$ & $(-) 3,592$ \\
\hline HP148 & 1 & 298 & Europeu & $\mathrm{V}$ & $(-) 3,592$ \\
\hline
\end{tabular}

Total : 68 haplótipos / 104 Sequências 


\section{2 - Redes de Haplótipos (Networks)}

Os resultados das redes estão representados nas Figuras 10 e 11 para os sub-haplogrupos L1b e L1c, respectivamente, e, na Figura 12, para o haplogrupo L1 como um todo. A figura 13 representa a rede obtida para o haplogrupo L2, a figura 14 para o haplogrupo L3. Os haplogrupos ameríndios (A, B, C e D) estão representados nas Figuras 15 (A e B) e 16 (C e D), respectivamente. Finalmente, o conjunto de haplótipos ameríndios está representado na Figura 17 e o conjunto de haplótipos africanos está representado na Figura 18.

\section{Sub-Haplogrupo L1b}

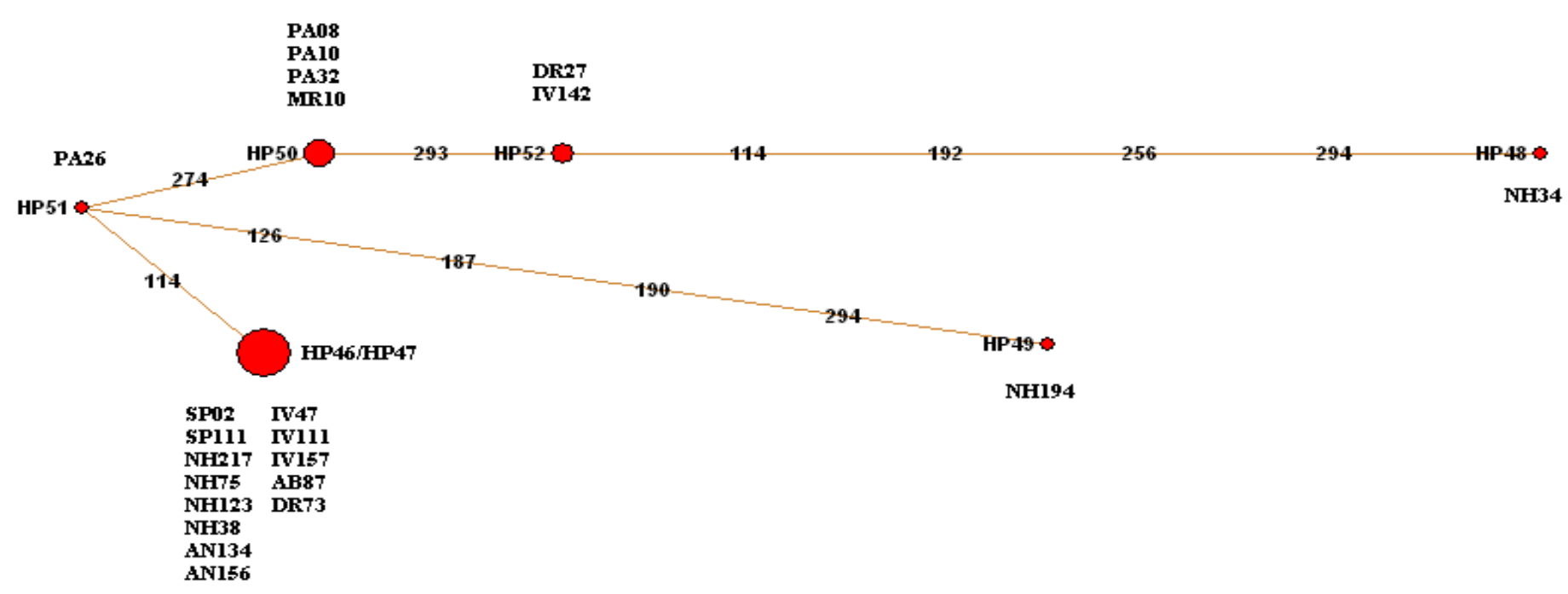

Figura 10 - Rede das linhagens do sub-haplogrupo L1b africano, presentes nas comunidades remanescentes de quilombos do Vale do Ribeira. Os círculos representam os haplótipos detectados e a área de cada círculo é proporcional à frequência do haplótipo. A linha contínua que conecta os círculos representa as diferenças genéticas. Ao lado de cada círculo foram indicadas as amostras sequenciadas em que foi observado o haplótipo. A nomenclatura das populações é: AN (André Lópes), GA (Galvão), MR (Maria Rosa), PC (Pedro Cubas), PS (Pilões), SP (São Pedro), TU (Sapatu), DR (Abobral Margem Direita), AB (Abobral Margem Esquerda), IV (Ivaporunduva), NH (Nhunguara) e PA (Poça). 


\section{Sub-Haplogrupo L1c}

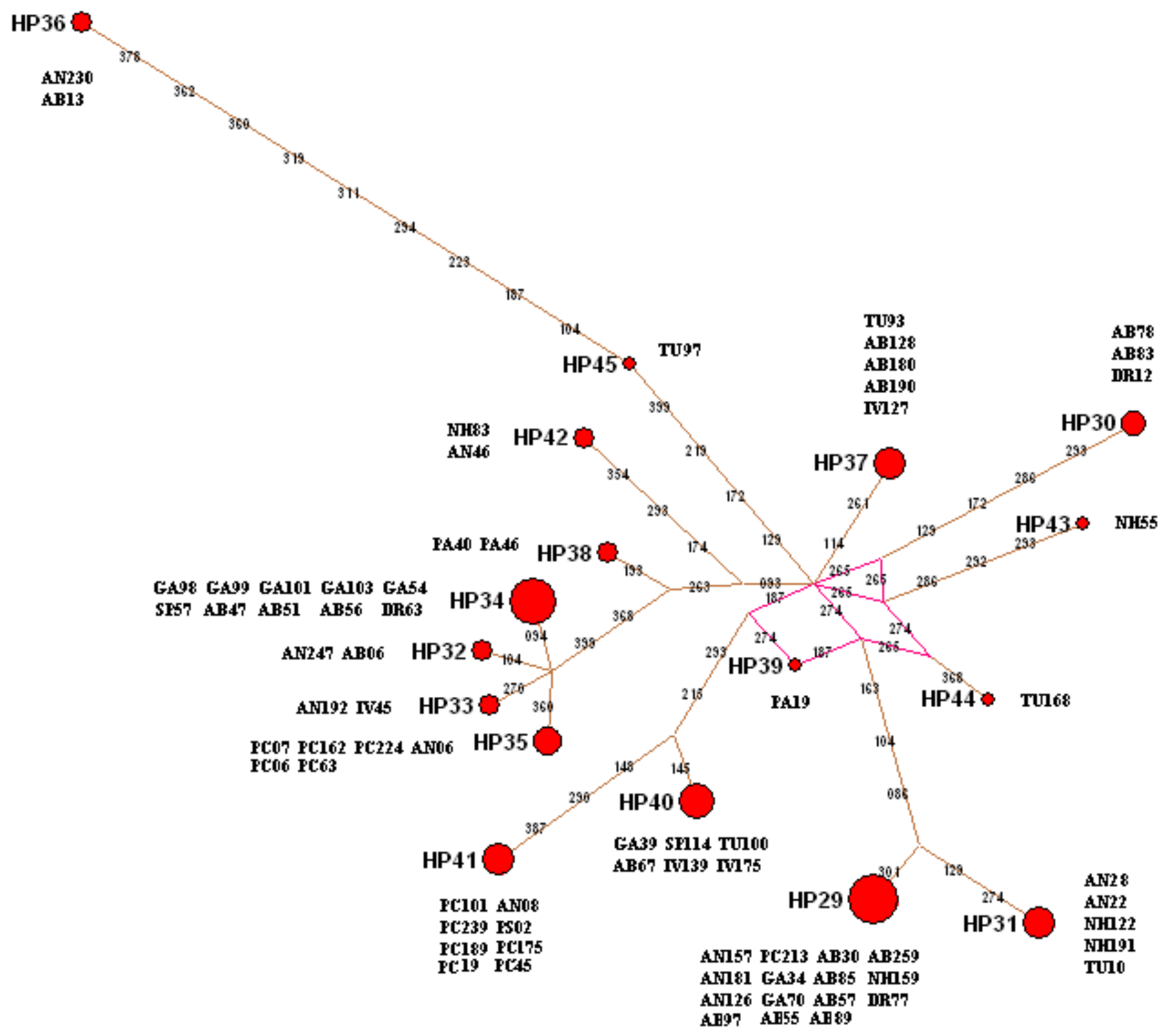

Figura 11 - Rede das linhagens do sub-haplogrupo L1c africano, presentes nas comunidades remanescentes de quilombos do Vale do Ribeira. Os círculos representam os haplótipos detectados e a área de cada círculo é proporcional à frequência do haplótipo. A linha contínua que conecta os círculos representa as diferenças genéticas. Ao lado de cada círculo foram indicadas as amostras sequenciadas em que foi observado o haplótipo. A nomenclatura das populações é: AN (André Lópes), GA (Galvão), MR (Maria Rosa), PC (Pedro Cubas), PS (Pilões), SP (São Pedro), TU (Sapatu), DR (Abobral Margem Direita), AB (Abobral Margem Esquerda), IV (Ivaporunduva), NH (Nhunguara) e PA (Poça). 


\section{Haplogrupo L1}

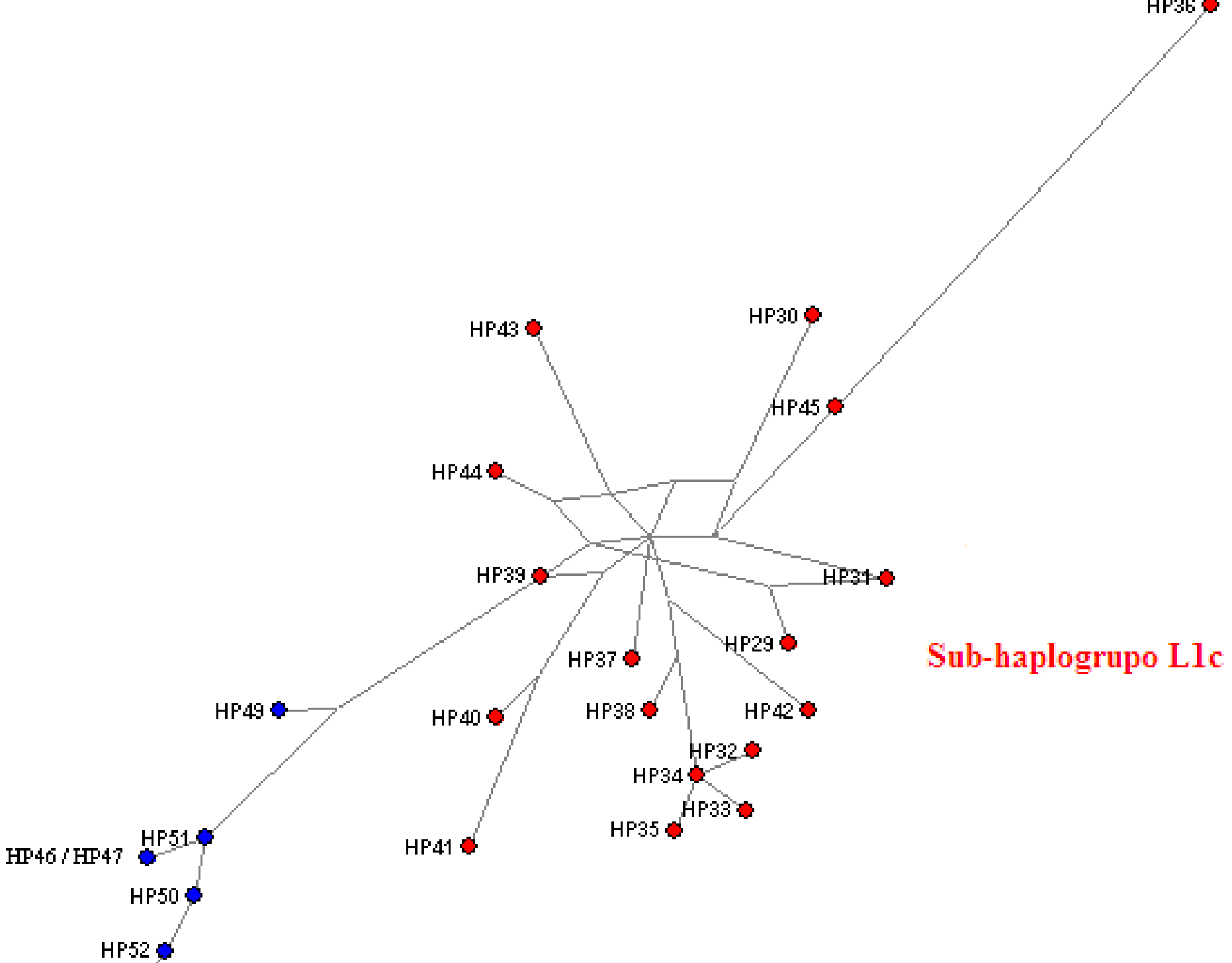

\section{Sub-haplogrupo Llb}

Figura 12 - Rede das linhagens do haplogrupo L1 africano, presentes nas comunidades remanescentes de quilombos do Vale do Ribeira. Os círculos representam os haplótipos detectados e a linha contínua que conecta os círculos representa as diferenças genéticas. Por uma questão de clareza não foram representadas a frequência dos haplótipos, as mutações e as amostras pertencentes a cada um dos haplótipos detectados. 


\section{Haplogrupo L2}

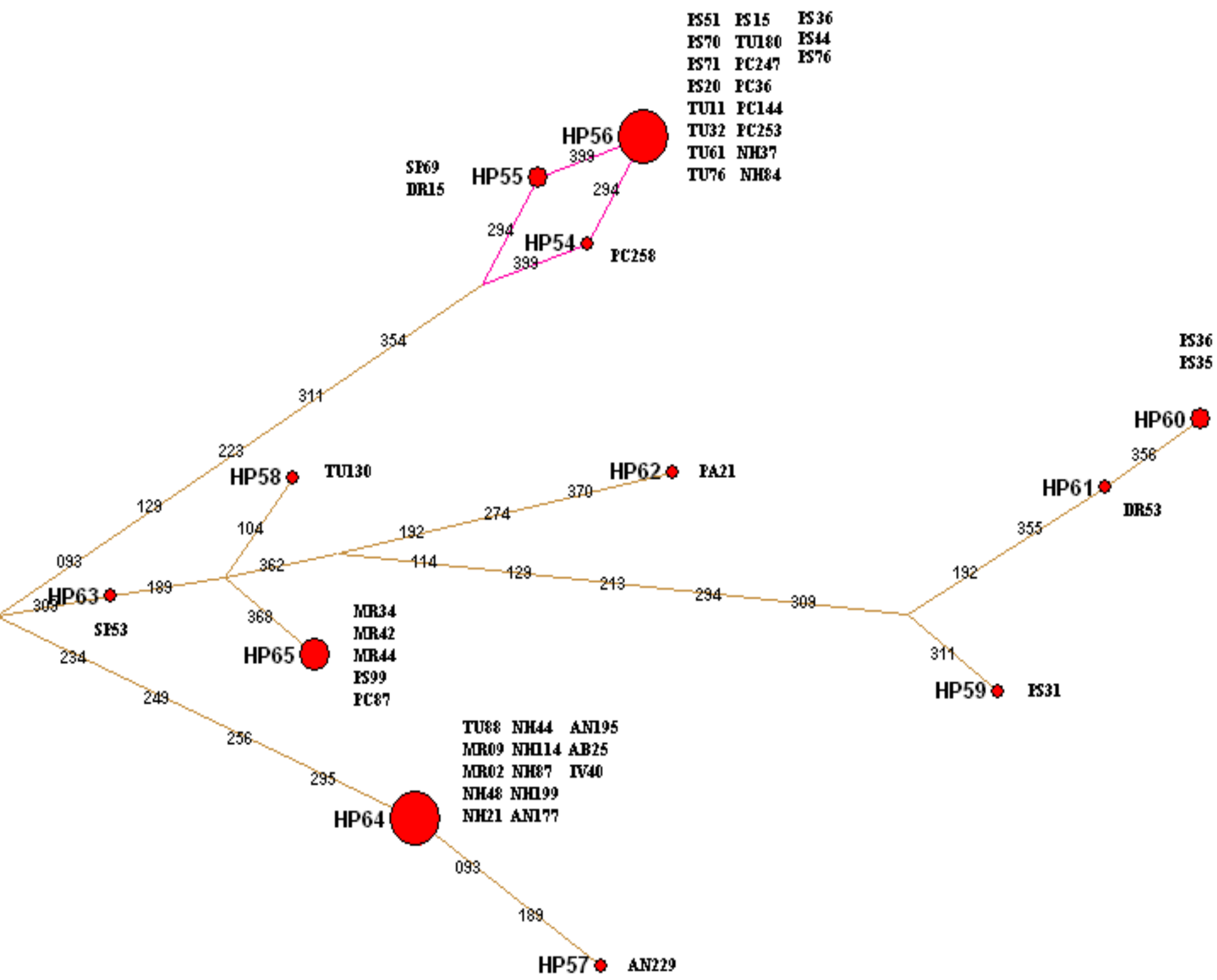

Figura 13 - Rede das linhagens do haplogrupo L2 africano, presentes nas comunidades remanescentes de quilombos do Vale do Ribeira. Os círculos representam os haplótipos detectados e a área de cada círculo é proporcional à frequência do haplótipo. A linha contínua que conecta os círculos representa as diferenças genéticas. Ao lado de cada círculo foram indicadas as amostras sequenciadas em que foi observado o haplótipo. A nomenclatura das populações é: AN (André Lópes), GA (Galvão), MR (Maria Rosa), PC (Pedro Cubas), PS (Pilões), SP (São Pedro), TU (Sapatu), DR (Abobral Margem Direita), AB (Abobral Margem Esquerda), IV (Ivaporunduva), NH (Nhunguara) e PA (Poça). 


\section{Haplogrupo L3}

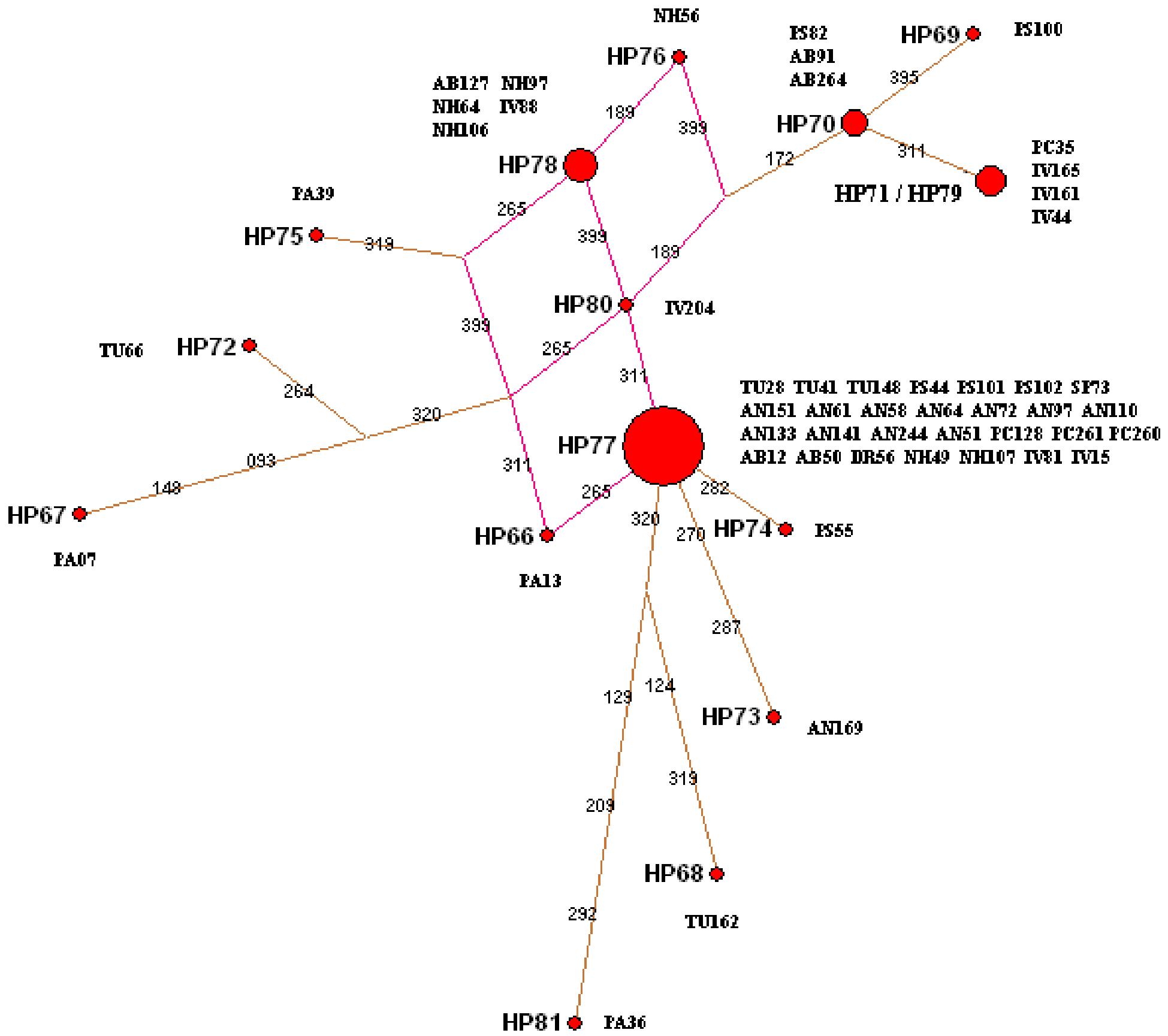

Figura 14 - Rede das linhagens do haplogrupo L3 africano, presentes nas comunidades remanescentes de quilombos do Vale do Ribeira. Os círculos representam os haplótipos detectados e a área de cada círculo é proporcional à frequência do haplótipo. A linha contínua que conecta os círculos representa as diferenças genéticas. Ao lado de cada círculo foram indicadas as amostras sequenciadas em que foi observado o haplótipo. A nomenclatura das populações é: AN (André Lópes), GA (Galvão), MR (Maria Rosa), PC (Pedro Cubas), PS (Pilões), SP (São Pedro), TU (Sapatu), DR (Abobral Margem Direita), AB (Abobral Margem Esquerda), IV (Ivaporunduva), NH (Nhunguara) e PA (Poça). 


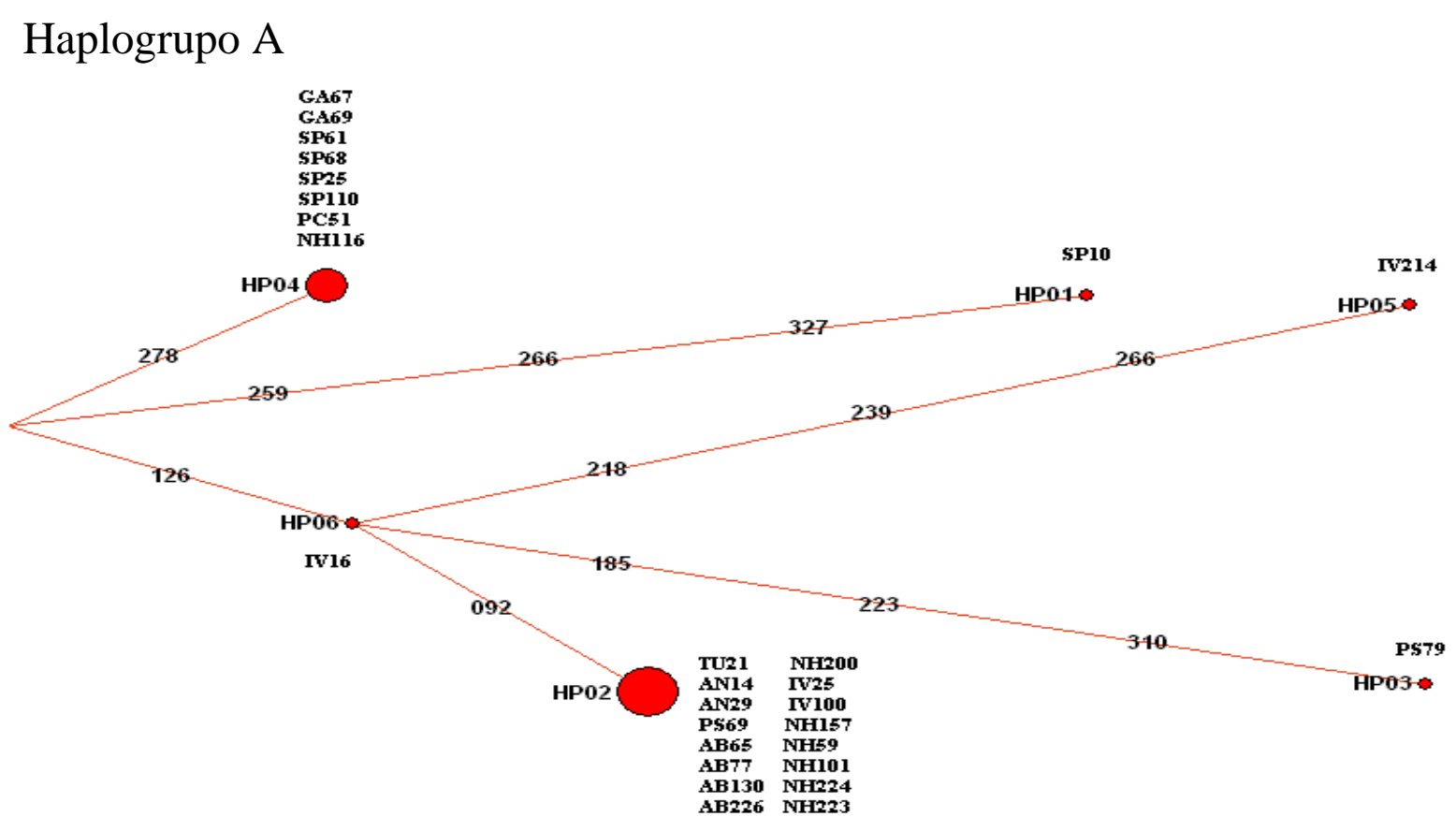

\section{Haplogrupo B}

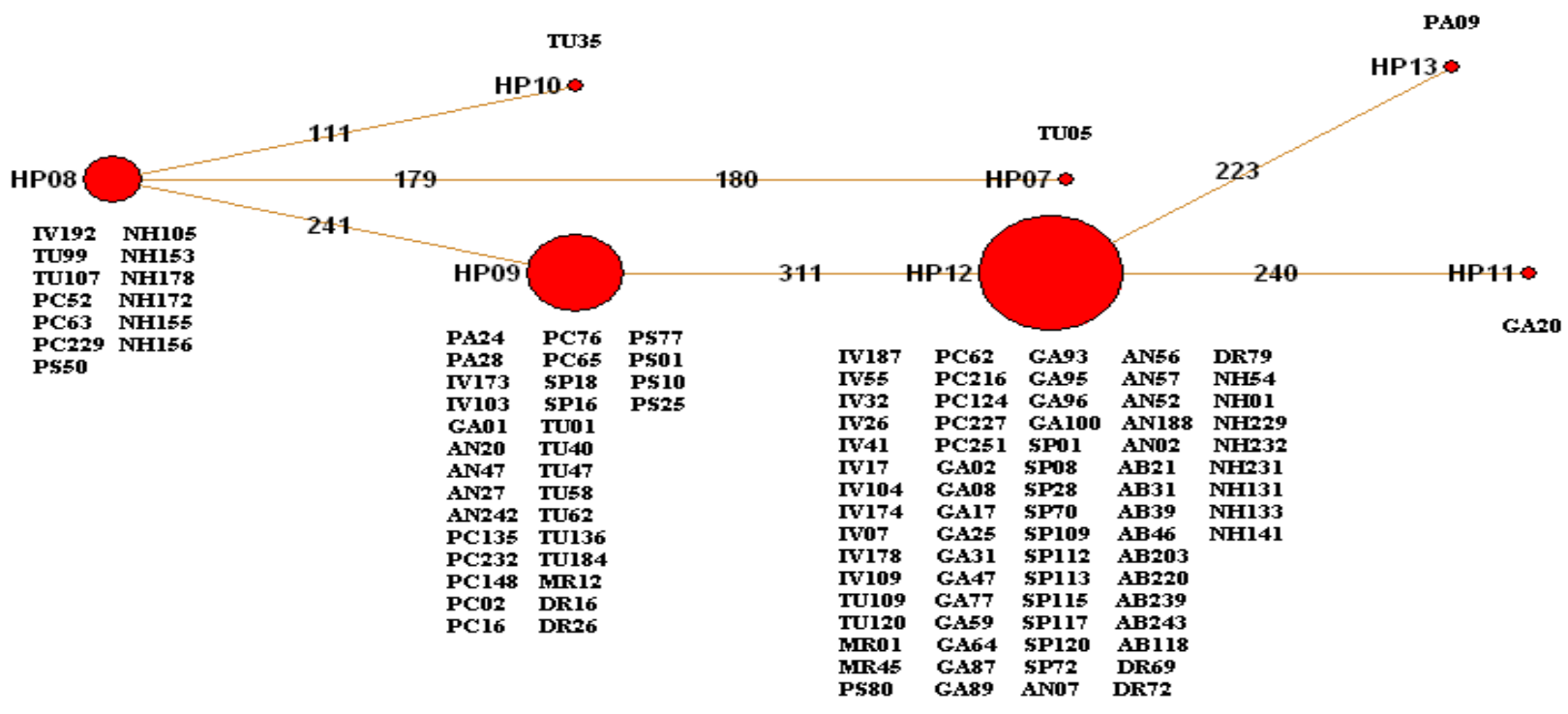

Figura 15 - Rede das linhagens dos haplogrupos A e B amerindios, presentes nas comunidades remanescentes de quilombos do Vale do Ribeira. Os círculos representam os haplótipos detectados e a área de cada círculo é proporcional à frequência do haplótipo. A linha contínua que conecta os círculos representa as diferenças genéticas. Ao lado de cada círculo foram indicadas as amostras sequenciadas em que foi observado o haplótipo. A nomenclatura das populações é: AN (André Lópes), GA (Galvão), MR (Maria Rosa), PC (Pedro Cubas), PS (Pilões), SP (São Pedro), TU (Sapatu), DR (Abobral Margem Direita), AB (Abobral Margem Esquerda), IV (Ivaporunduva), NH (Nhunguara) e PA (Poça). 


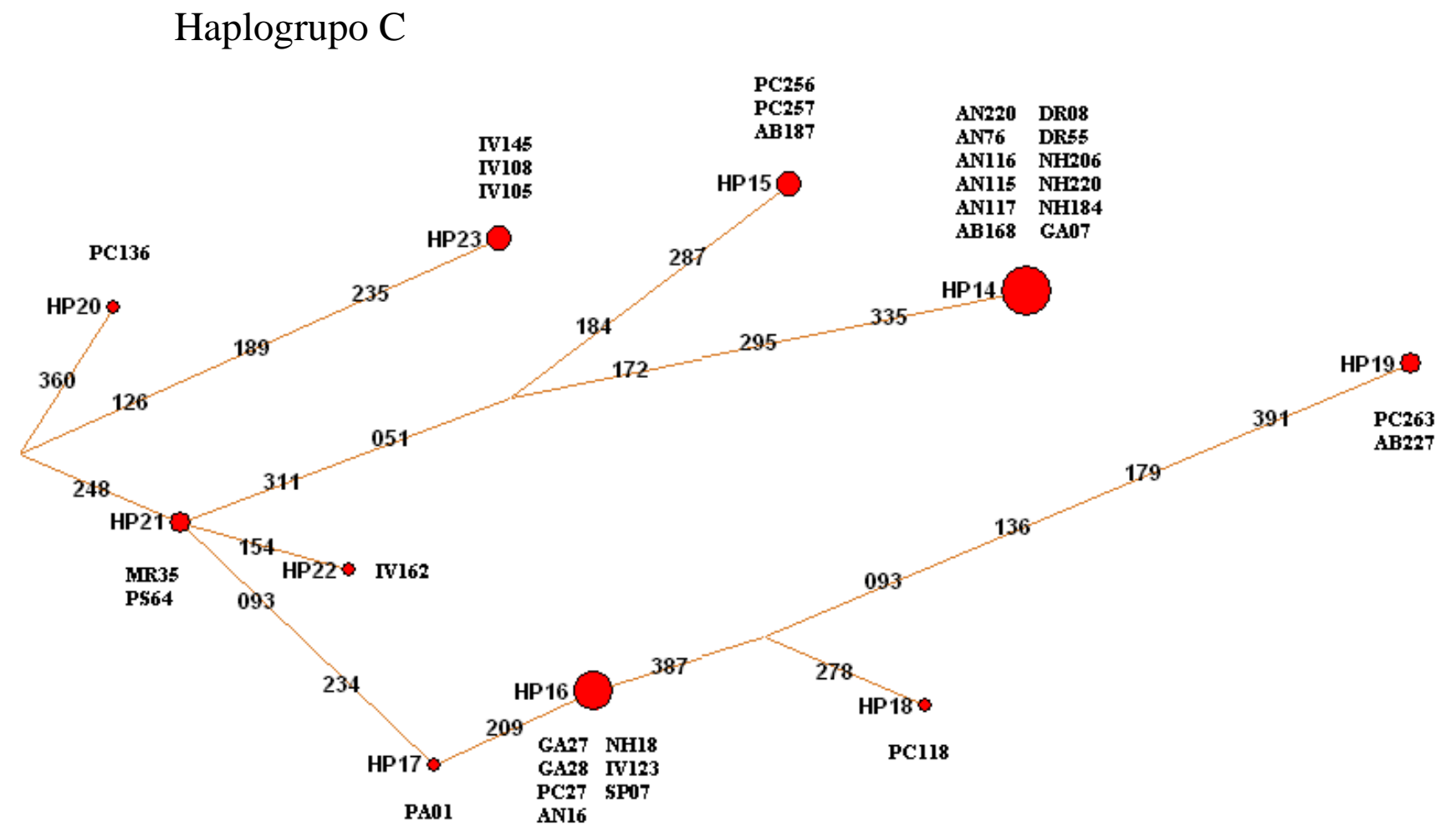

\section{Haplogrupo D}

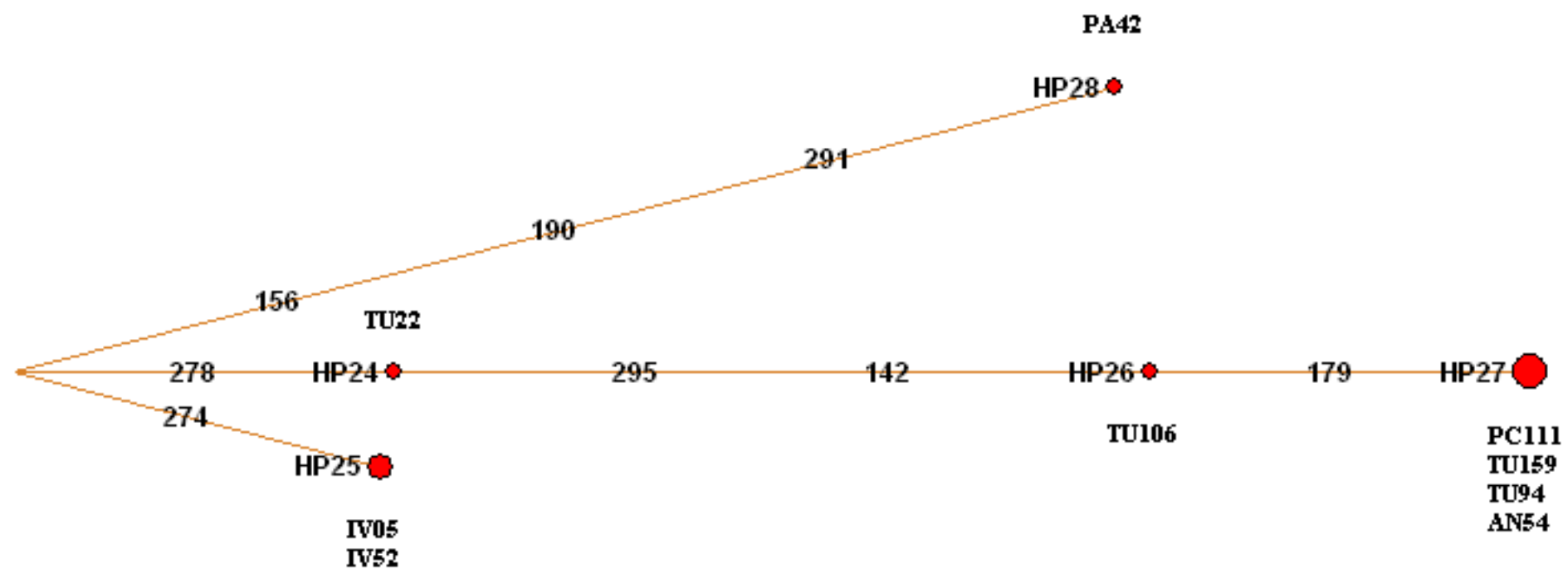

Figura 16 - Rede das linhagens dos haplogrupo C e D ameríndios, presentes nas comunidades remanescentes de quilombos do Vale do Ribeira. Os círculos representam os haplótipos detectados e a área desses círculos é proporcional a frequencia do haplótipo. A linha contínua que conecta os círculos representa as diferenças genéticas. Ao lado de cada círculo foram indicadas as amostras sequenciadas que foram classificadas no haplótipo em questão. A nomenclatura das populações corresponde: AN (André Lópes), GA (Galvão), MR (Maria Rosa), PC (Pedro Cubas), PS (Pilões), SP (São Pedro), TU (Sapatu), DR (Abobral Margem Direita), AB (Abobral Margem Esquerda), IV (Ivaporunduva), NH (Nhunguara) e PA (Poça). 


\section{Fração Ameríndia}

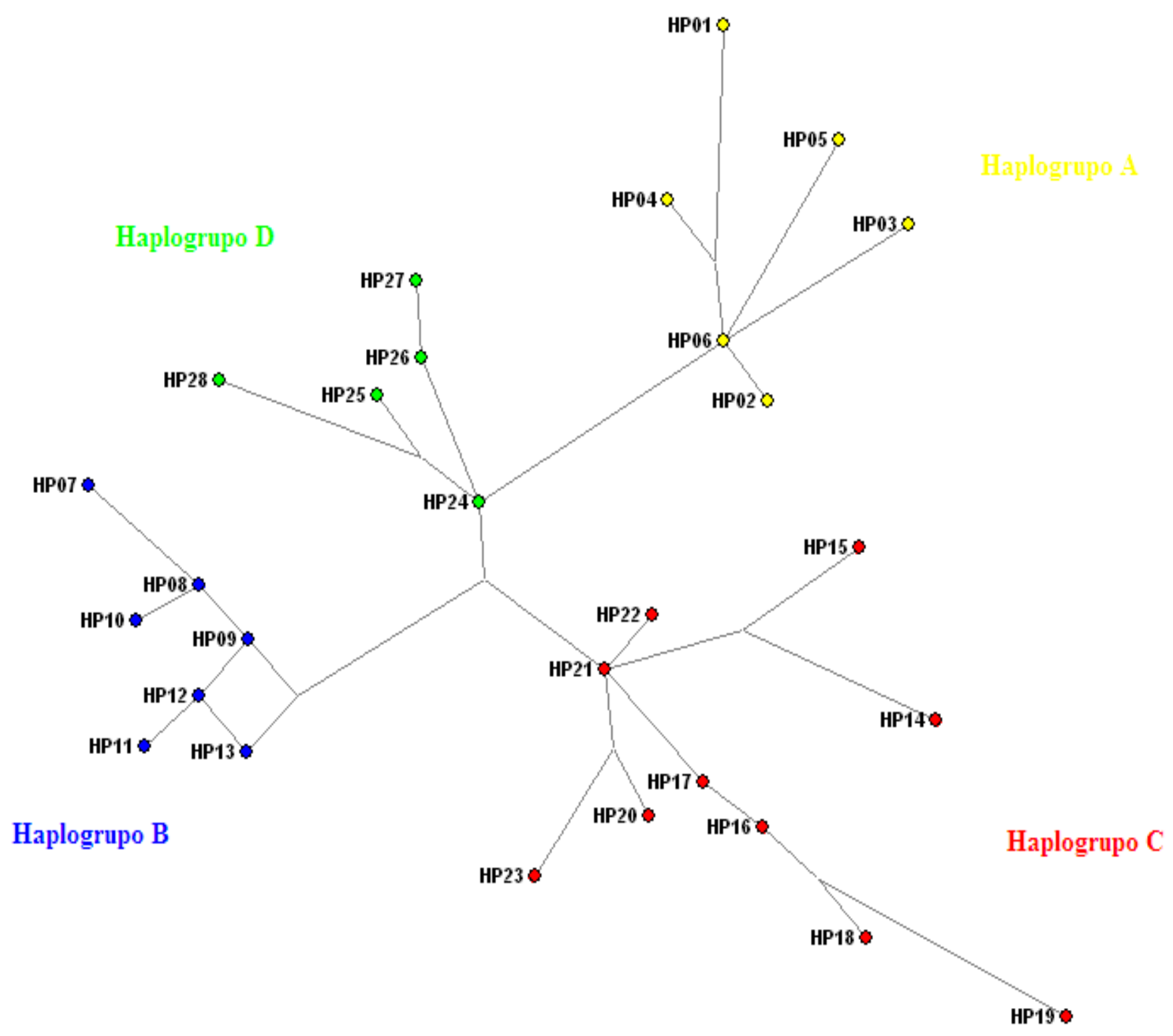

Figura 17 - Rede de todas as linhagens ameríndias presentes nas comunidades remanescentes de quilombos do Vale do Ribeira. Os círculos representam os haplótipos detectados e a linha contínua que conecta os círculos representa as diferenças genéticas. Por uma questão de clareza não foram representadas a frequência dos haplótipos, as mutações e as amostras pertencentes a cada um dos haplótipos detectados. 


\section{Fração Africana}

\section{Haplogrupo L2}

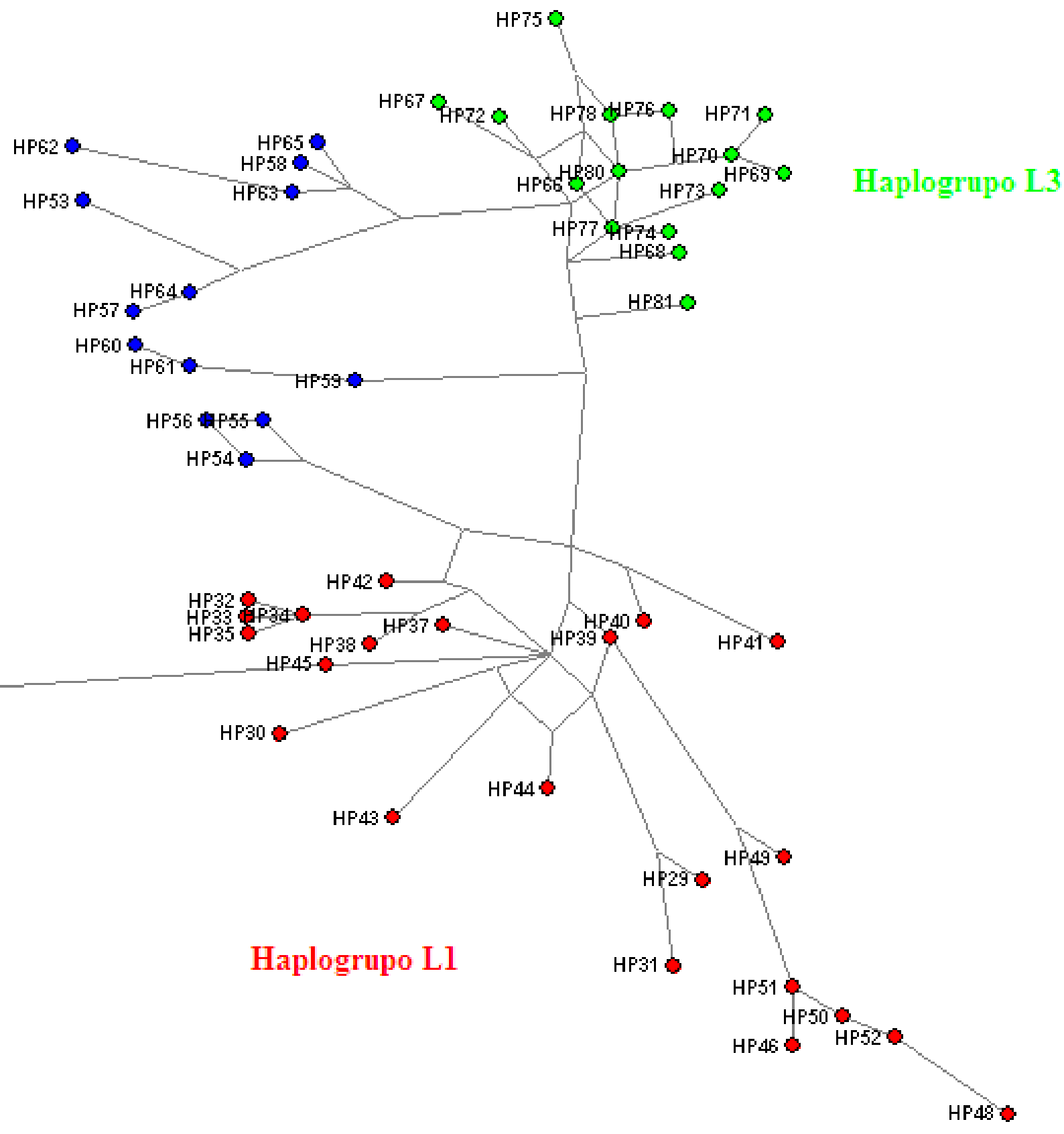

Figura 18 - Rede de todas as linhagens africanas presentes nas comunidades remanescentes de quilombos do Vale do Ribeira. Os círculos representam os haplótipos detectados e a linha contínua que conecta os círculos representa as diferenças genéticas. Por uma questão de clareza não foram representadas a frequência dos haplótipos, as mutações e as amostras pertencentes a cada um dos haplótipos detectados. 
No sub-haplogrupo L1b não foi observada formação de reticulação, diferentemente do sub-haplogrupo L1c. Reticulações foram também observadas nos haplogrupos L2 e L3. Todos os haplogrupos ameríndios apresentaram árvores livres de reticulações.

A reunião de todas as linhagens ameríndias presentes entre as comunidades remanescentes de quilombos, em uma única rede, permitiu observar claramente as relações filogenéticas entre os quatro principais haplogrupos identificados na América (Figura 17). Em relação à fração africana (Figura 18), as relações são menos claras, o que pode ser reflexo do maior tempo evolutivo dessas linhagens. Assim mesmo, nessa rede foi possível identificar a formação de agrupamentos que correspondem aos haplogrupos africanos (L1, L2 e L3).

\section{3 - Estimativas de Diversidade Genética}

\subsection{1 - Diversidade haplotípica e nucleotídica}

Os valores das diversidades haplotípicas $(\mathrm{Hd})$ e nucleotídicas $(\pi)$, com seus respectivos desvios padrão, são representados na Tabela $\mathrm{V}$.

Os cálculos das diversidades haplotípicas e nucleotídicas foram realizadas da seguinte forma: (i) para cada haplogrupo ameríndio e africano detectado nos afro-descendentes do Vale do Ribeira; (ii) para cada uma das doze populações remanescentes de quilombos do Vale do Ribeira e na cidade de São Paulo, de forma isolada; (iii) para as frações ameríndias e africanas de cada população; (iv) para as doze populações remanescentes de quilombos reunidas, representando os afro-descendentes do Vale do Ribeira; (v) para as frações

ameríndias e africanas das doze populações remanescentes de quilombos do Vale do Ribeira reunidas.

Entre as populações remanescentes de quilombos do Vale do Ribeira, os valores de Hd apresentaram valores entre 0,7701 (Galvão) a 0,9524 (Abobral Margem Direita e Poça), enquanto no conjunto total das populações, o valor foi de 0,9442. Os valores de $\pi$ apresentaram variação de 0,016257 (São Pedro) a 0,21832 (Abobral Margem Direita); o valor para o conjunto total de populações remanescentes de quilombos investigadas foi de 0,019758. A amostra de São Paulo apresentou valores de diversidade haplotípica de 0,9862 e nucleotídica de 0,016680 (Tabela V). 
Tabela V - Diversidades haplotípicas e nucleotídicas nas amostras dos remanescentes de quilombos do Vale do Ribeira e de uma amostra da cidade de São Paulo com base na região hipervariável I do DNA mitocondrial.

\begin{tabular}{|c|c|c|c|c|c|c|c|}
\hline \multicolumn{2}{|c|}{ Haplogrupos } & $\mathbf{N}$ & $\mathbf{S}$ & h & Hd & $\pi$ & $\mathbf{K}$ \\
\hline & Haplogrupo A & 28 & 11 & 6 & $0.6085 \pm 0.0778$ & $0.004512 \pm 0.002912$ & $2.021164 \pm 1.171872$ \\
\hline & Haplogrupo B & 117 & 8 & 8 & $0.5703 \pm 0.0388$ & $0.001760 \pm 0.001426$ & $0.788388 \pm 0.576758$ \\
\hline & Haplogrupo C & 33 & 21 & 11 & $0.8314 \pm 0.0498$ & $0.012108 \pm 0.006654$ & $5.424242 \pm 2.680579$ \\
\hline & Haplogrupo D & 9 & 12 & 6 & $0.8333 \pm 0.1265$ & $0.008557 \pm 0.005383$ & $3.833333 \pm 2.125602$ \\
\hline & Haplogrupo L1 & 87 & 44 & 27 & $0.9380 \pm 0.0111$ & $0.018600 \pm 0.009636$ & $8.332799 \pm 3.896592$ \\
\hline & Haplogrupo L2 & 44 & 29 & 13 & $0.8066 \pm 0.0408$ & $0.017083 \pm 0.009015$ & $7.653277 \pm 3.637365$ \\
\hline & Haplogrupo L3 & 50 & 18 & 15 & $0.6980 \pm 0.0695$ & $0.004747 \pm 0.002982$ & $2.126531 \pm 1.203881$ \\
\hline \multicolumn{2}{|c|}{ Populações } & $\mathbf{N}$ & $\mathbf{S}$ & $\mathbf{h}$ & Hd & $\pi$ & $\mathbf{K}$ \\
\hline \multirow[t]{3}{*}{ AbobralD } & Total & 15 & 39 & 11 & $0.9524 \pm 0.0403$ & $0.021832 \pm 0.011880$ & $9.780952 \pm 4.746807$ \\
\hline & Fração Ameríndia & 7 & 11 & 3 & $0.7619 \pm 0.1148$ & $0.011692 \pm 0.007367$ & $5.238095 \pm 2.881267$ \\
\hline & Fração Africana & 8 & 32 & 8 & $1.0000 \pm 0.0625$ & $0.024394 \pm 0.014158$ & $10.928571 \pm 5.567987$ \\
\hline \multirow[t]{3}{*}{ AbobralE } & Total & 38 & 54 & 17 & $0.9189 \pm 0.0276$ & $0.022779 \pm 0.011817$ & $10.204836 \pm 4.764437$ \\
\hline & Fração Ameríndia & 16 & 24 & 5 & $0.6500 \pm 0.1083$ & $0.014769 \pm 0.008246$ & $6.616667 \pm 3.298124$ \\
\hline & Fração Africana & 22 & 38 & 12 & $0.9351 \pm 0.0287$ & $0.021394 \pm 0.011379$ & $9.584416 \pm 4.569227$ \\
\hline \multirow[t]{3}{*}{ André Lópes } & Total & 50 & 54 & 23 & $0.9249 \pm 0.0226$ & $0.019973 \pm 0.010385$ & $8.947755 \pm 4.192175$ \\
\hline & Fração Ameríndia & 19 & 21 & 6 & $0.8129 \pm 0.0505$ & $0.015142 \pm 0.008341$ & $6.783626 \pm 3.343918$ \\
\hline & Fração Africana & 28 & 46 & 14 & $0.8413 \pm 0.0646$ & $0.020993 \pm 0.011061$ & $9.404762 \pm 4.450912$ \\
\hline \multirow[t]{3}{*}{ Galvão } & Total & 30 & 38 & 11 & $0.7701 \pm 0.0746$ & $0.018560 \pm 0.009842$ & $8.314943 \pm 3.962108$ \\
\hline & Fração Ameríndia & 22 & 22 & 7 & $0.5842 \pm 0.1270$ & $0.010468 \pm 0.005976$ & $4.689474 \pm 2.397122$ \\
\hline & Fração Africana & 8 & 14 & 4 & $0.7500 \pm 0.1391$ & $0.012436 \pm 0.007611$ & $5.571429 \pm 2.993252$ \\
\hline \multirow[t]{3}{*}{ Ivaporunduva } & Total & 42 & 45 & 22 & $0.9315 \pm 0.0275$ & $0.017126 \pm 0.009046$ & $7.672474 \pm 3.649117$ \\
\hline & Fração Ameríndia & 25 & 25 & 11 & $0.8300 \pm 0.0677$ & $0.013214 \pm 0.007272$ & $5.920000 \pm 2.923485$ \\
\hline & Fração Africana & 16 & 27 & 10 & $0.9333 \pm 0.0399$ & $0.018322 \pm 0.010046$ & $8.208333 \pm 4.018188$ \\
\hline \multirow[t]{3}{*}{ Maria Rosa } & Total & 10 & 21 & 6 & $0.8889 \pm 0.0754$ & $0.016815 \pm 0.009705$ & $7.533333 \pm 3.844435$ \\
\hline & Fração Ameríndia & 4 & 7 & 3 & $0.8333 \pm 0.2224$ & $0.008185 \pm 0.006219$ & $3.666667 \pm 2.333333$ \\
\hline & Fração Africana & 6 & 15 & 3 & $0.7333 \pm 0.1552$ & $0.014137 \pm 0.009019$ & $6.333333 \pm 3.499206$ \\
\hline \multirow[t]{3}{*}{ Nhunguara } & Total & 51 & 47 & 19 & $0.9318 \pm 0.0151$ & $0.021703 \pm 0.011215$ & $9.723137 \pm 4.527816$ \\
\hline & Fração Ameríndia & 25 & 28 & 7 & $0.8133 \pm 0.0432$ & $0.016101 \pm 0.008699$ & $7.213333 \pm 3.497262$ \\
\hline & Fração Africana & 26 & 33 & 13 & $0.9169 \pm 0.0331$ & $0.021813 \pm 0.011498$ & $9.772308 \pm 4.624058$ \\
\hline \multirow[t]{3}{*}{ Pedro Cubas } & Total & 40 & 47 & 18 & $0.9359 \pm 0.0189$ & $0.019365 \pm 0.010145$ & $8.675641 \pm 4.091267$ \\
\hline & Fração Ameríndia & 22 & 28 & 10 & $0.8571 \pm 0.0537$ & $0.013741 \pm 0.007578$ & $6.155844 \pm 3.042750$ \\
\hline & Fração Africana & 17 & 27 & 8 & $0.8897 \pm 0.0431$ & $0.019105 \pm 0.010399$ & $8.558824 \pm 4.162691$ \\
\hline
\end{tabular}


Tabela V - Continuação.

\begin{tabular}{|c|c|c|c|c|c|c|c|}
\hline \multicolumn{2}{|c|}{ Populações } & \multirow{2}{*}{$\frac{\mathbf{N}}{24}$} & \multirow{2}{*}{$\frac{\mathbf{S}}{37}$} & \multirow{2}{*}{$\frac{\mathbf{h}}{15}$} & \multirow{2}{*}{$\frac{\text { Hd }}{0.9420 \pm 0.0286}$} & \multirow{2}{*}{$\frac{\pi}{0.017898 \pm 0.009604}$} & \multirow{2}{*}{$\frac{\mathbf{K}}{8.018116 \pm 3.859506}$} \\
\hline Pilões & Total & & & & & & \\
\hline & Fração Ameríndia & 9 & 15 & 6 & $0.8333 \pm 0.1265$ & $0.010541 \pm 0.006457$ & $4.722222 \pm 2.549906$ \\
\hline & Fração Africana & 14 & 26 & 8 & $0.8901 \pm 0.0603$ & $0.018299 \pm 0.010139$ & $8.197802 \pm 4.046334$ \\
\hline \multirow[t]{3}{*}{ Poça } & Total & 22 & 42 & 15 & $0.9524 \pm 0.0291$ & $0.019510 \pm 0.010444$ & $8.740260 \pm 4.193792$ \\
\hline & Fração Ameríndia & 5 & 14 & 4 & $0.9000 \pm 0.1610$ & $0.014286 \pm 0.009528$ & $6.400000 \pm 3.651127$ \\
\hline & Fração Africana & 12 & 28 & 9 & $0.9394 \pm 0.0577$ & $0.020360 \pm 0.011352$ & $9.121212 \pm 4.516843$ \\
\hline \multirow[t]{3}{*}{ São Pedro } & Total & 26 & 36 & 11 & $0.8062 \pm 0.0706$ & $0.016257 \pm 0.008761$ & $7.283077 \pm 3.523418$ \\
\hline & Fração Ameríndia & 19 & 18 & 5 & $0.6374 \pm 0.1045$ & $0.011644 \pm 0.006585$ & $5.216374 \pm 2.639942$ \\
\hline & Fração Africana & 7 & 24 & 6 & $0.9524 \pm 0.0955$ & $0.021259 \pm 0.012734$ & $9.523810 \pm 4.980395$ \\
\hline \multirow[t]{3}{*}{ Sapatu } & Total & 37 & 46 & 22 & $0.9444 \pm 0.0230$ & $0.017318 \pm 0.009170$ & $7.758258 \pm 3.696779$ \\
\hline & Fração Ameríndia & 18 & 15 & 9 & $0.8431 \pm 0.0756$ & $0.009322 \pm 0.005434$ & $4.176471 \pm 2.176894$ \\
\hline & Fração Africana & 16 & 33 & 11 & $0.9083 \pm 0.0633$ & $0.019568 \pm 0.010677$ & $8.766667 \pm 4.270535$ \\
\hline \multirow[t]{3}{*}{ Vale do Ribeira } & Total & 385 & 90 & 93 & $0.9442 \pm 0.0066$ & $0.019758 \pm 0.010098$ & $8.513080 \pm 4.090239$ \\
\hline & Fração Ameríndia & 187 & 46 & 31 & $0.8184 \pm 0.0224$ & $0.012982 \pm 0.006901$ & $5.816112 \pm 2.793733$ \\
\hline & Fração Africana & 181 & 58 & 54 & $0.9517 \pm 0.0072$ & $0.021530 \pm 0.010971$ & $8.945488 \pm 4.441248$ \\
\hline \multirow[t]{3}{*}{ São Paulo } & Total & 105 & 67 & 75 & $0.9862 \pm 0.0048$ & $0.016680 \pm 0.008700$ & $7.472741 \pm 3.519416$ \\
\hline & Fração Ameríndia & 38 & 31 & 27 & $0.9616 \pm 0.0211$ & $0.013542 \pm 0.007326$ & $6.066856 \pm 2.953485$ \\
\hline & Fração Africana & 49 & 47 & 37 & $0.9711 \pm 0.0159$ & $0.017250 \pm 0.009074$ & $7.727891 \pm 3.662676$ \\
\hline
\end{tabular}

$\mathrm{N}$ : número de indivíduos, $\mathrm{S}$ : número de sítios polimórficos, h: número de haplótipos, Hd: diversidade haplotípica, $\pi$ : diversidade nucleotídica, $\mathrm{K}$ : média do número de diferenças nucleotídicas. AbobralD: Abobral Margem Direita; AbobralE: Abobral Margem Direita.

\subsection{2 - Distribuição das diferenças par-a-par}

A análise das diferenças nucleotídicas entre os pares de indivíduos foi realizada com base nos resultados de sequenciamento da HVS-I do DNAmt, compreendeu 192 sequências ameríndias e 197 sequências africanas obtidas das doze populações do Vale do Ribeira e com base no conjunto de 401 sequências, considerando as populações de quilombos investigadas como um todo. Além disso, foram também analisadas as 104 sequências oriundas da cidade de São Paulo. Estes cálculos foram realizados da seguinte forma: (i) para os estoques de sequências de cada grupo étnico (africano e ameríndio) nas populações do Vale do Ribeira (Figuras 19 e 20, respectivamente), (ii) para o estoque total de sequências considerando as doze comunidades remanescentes de quilombos reunidas (Figura 21), (iii) para o estoque de sequências obtidas da cidade de São Paulo (Figura 22). 
Todas as análises revelaram uma distribuição que se aproxima da normal. Os valores dos índices de irregularidade (Harpending's Raggedness index) se mostraram baixos para todas as distribuições, o que fornece apoio estatístico à distribuição normal. Os testes de Tajima se mostraram todos negativos, com valores de $P$ significativos $(\mathrm{P}>0,05)$. Se considerarmos a região HVS-I do DNAmt como uma sequência livre de seleção, os valores obtidos neste caso são indicativos de eventos demográficos de expansão nas populações avaliadas.

No estoque ameríndio das comunidades de quilombos foi observada uma menor diversidade de sequências em relação ao estoque de sequências africanas. A média da distribuição de diferenças observadas em ameríndios foi de 5,8161 e no estoque africano a média foi de 8,9454. Considerando o estoque total de sequências das comunidades do Vale do Ribeira, a média da distribuição de diferenças $(8,5130)$ foi mais elevada que a média observada na amostragem de sequências da cidade de São Paulo $(7,4727)$.

No estoque ameríndio das comunidades de quilombos foi também observado um pico adicional significativo na posição que corresponde a zero (Figura 20). Este pico provavelmente é resultado da contribuição significativa, no conjunto de linhagens ameríndias, de alguns haplótipos predominantes, como por exemplo, um dos haplótipos pertencentes ao haplogrupo B (ver HAP 12 na Tabela III) muito frequente em praticamente todas as populações de quilombos do Vale do Ribeira. 
Estoque Africano: Média da distribuição de diferenças par-a-par: 8.9454

Harpending's Raggedness index: 0.01316564

Teste de Tajima : -0.08006

\section{Frequência relativa}

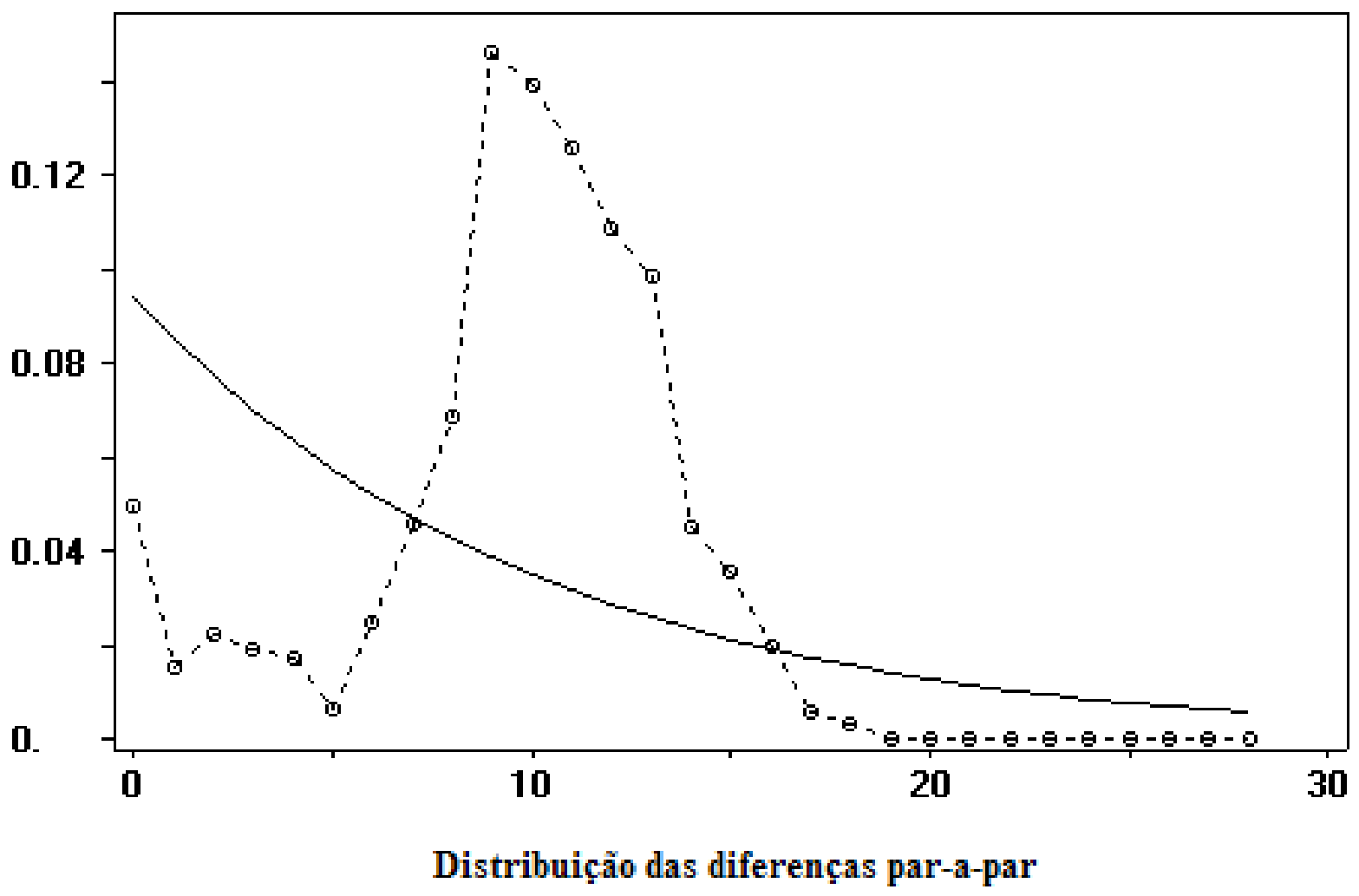

Figura 19 - Distribuição das diferenças par-a-par entre 197 sequências da região hipervariável do DNA mitocondrial de linhagens africanas de doze comunidades remanescentes de quilombos do Vale do Ribeira. A linha pontilhada (Obs) corresponde aos valores de distribuição calculados a partir dos dados de sequência coletados e a linha contínua (Exp) corresponde à distribuição esperada assumindo evolução neutra e tamanho populacional constante ao longo do tempo. 
Estoque Ameríndio: Média da distribuição de diferenças par-a-par: 5.8161

Harpending's Raggedness index: 0.03176516

Teste de Tajima: -0.71376

\section{Frequência relativa}

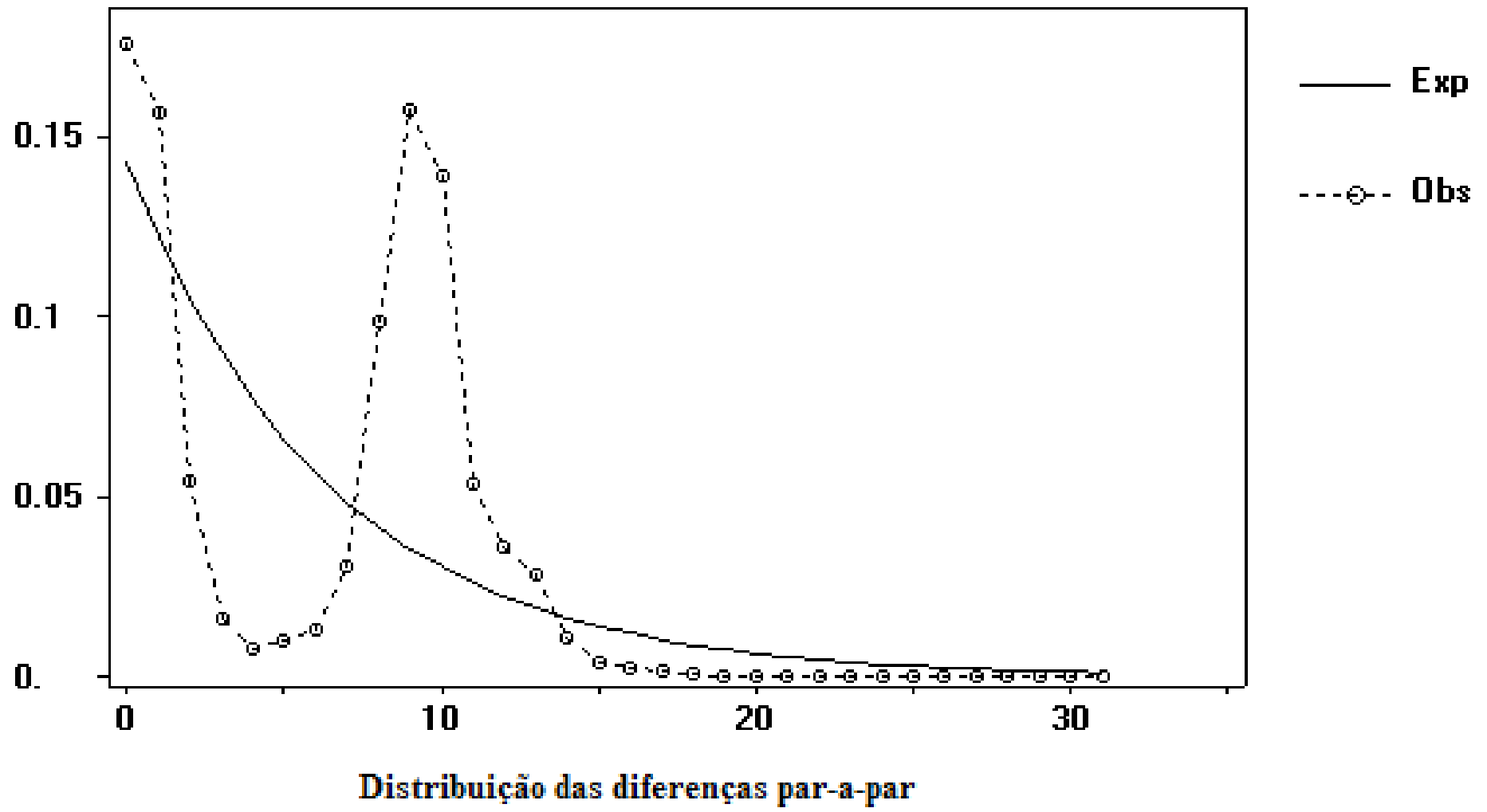

Figura 20 - Distribuição das diferenças par-a-par entre 192 sequências da região hipervariável I do DNA mitocondrial de linhagens ameríndias de doze comunidades remanescentes de quilombos do Vale do Ribeira. A linha pontilhada (Obs) corresponde aos valores de distribuição calculados a partir dos dados de sequência coletados e a linha contínua (Exp) corresponde à distribuição esperada assumindo evolução neutra e tamanho populacional constante ao longo do tempo. 


\section{Vale do Ribeira: Média da distribuição das diferenças par-a-par: 8.5130 \\ Harpending's Raggedness index: 0.00638082}

Teste de Tajima: -0.98829

\section{Frequência Relativa}

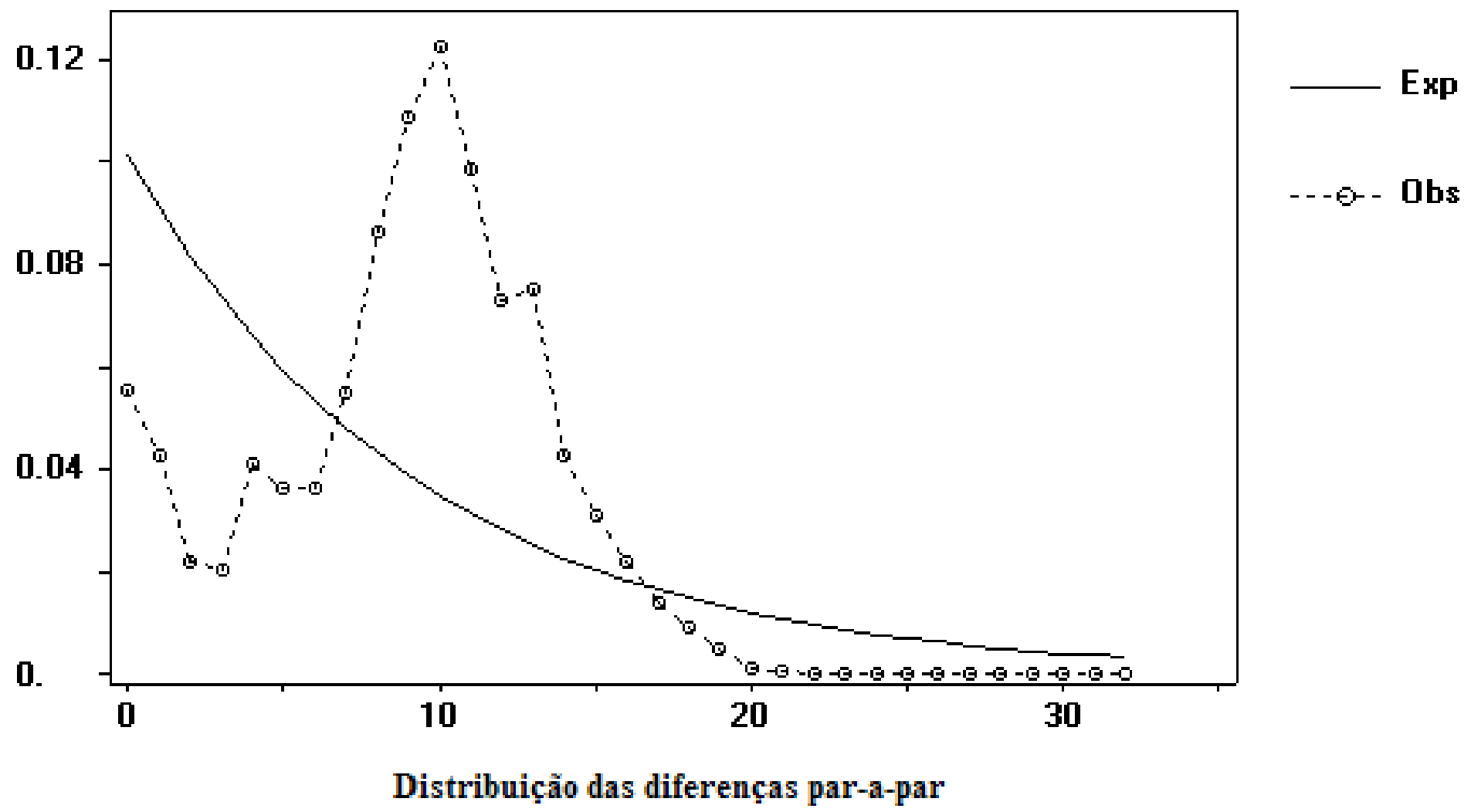

Figura 21 - Distribuição das diferenças par-a-par entre 382 sequências da região hipervariável I do DNA mitocondrial de linhagens das doze comunidades remanescentes de quilombos do Vale do Ribeira reunidas. A linha pontilhada (Obs) corresponde aos valores de distribuição calculados a partir dos dados de sequência coletados e a linha contínua (Exp) corresponde à distribuição esperada assumindo evolução neutra e tamanho populacional constante ao longo do tempo. 
São Paulo: Média da distribuição de diferenças par-a-par: 7.4727

Harpending's Raggedness index: 0.00702713

Teste de Tajima : -1.36304

\section{Frequência relativa}

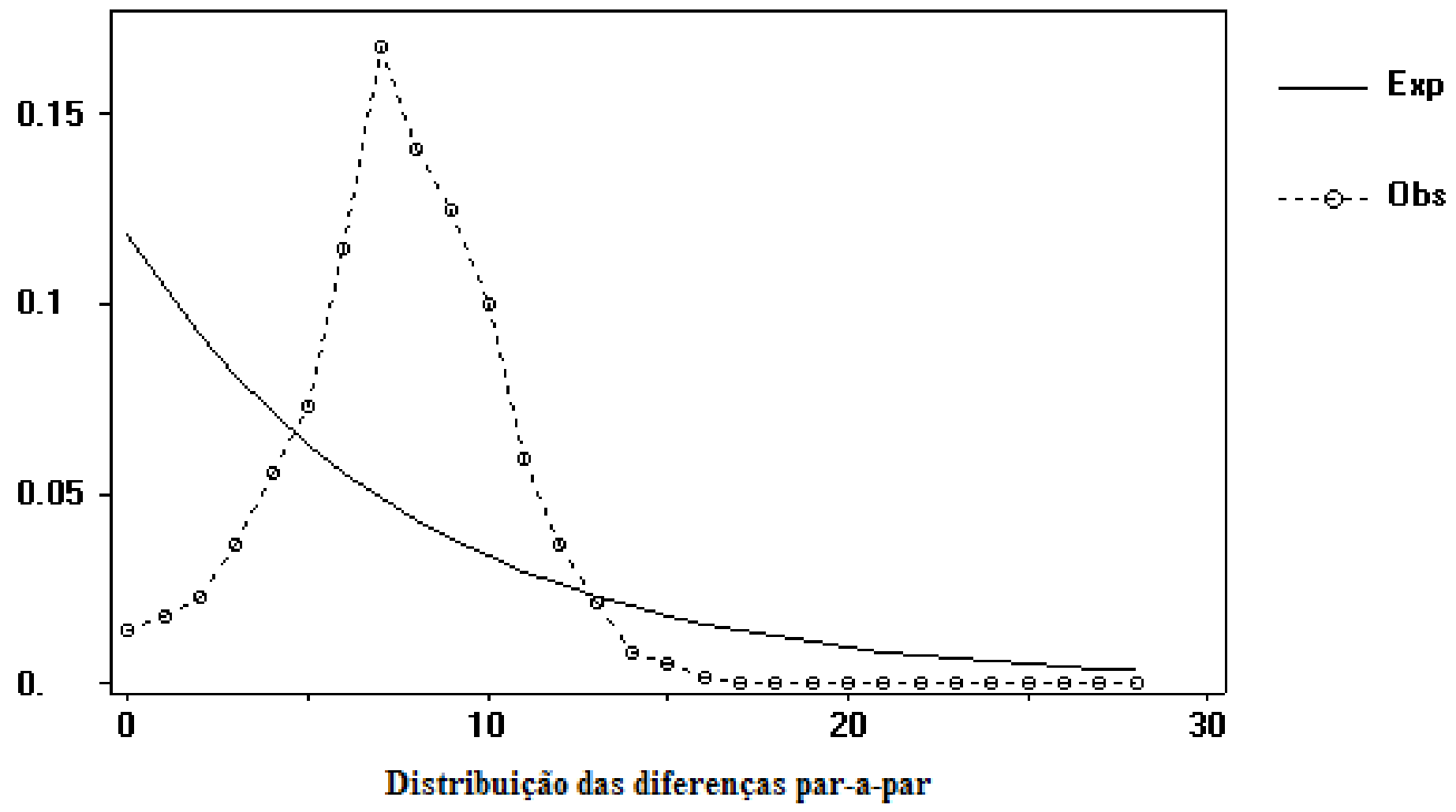

Figura 22 - Distribuição das diferenças par-a-par entre 104 sequências da região hipervariável I do DNA mitocondrial de linhagens da amostra da cidade de São Paulo. A linha pontilhada (Obs) corresponde aos valores de distribuição calculados a partir dos dados de sequência coletados e a linha contínua (Exp) corresponde à distribuição esperada assumindo evolução neutra e tamanho populacional constante ao longo do tempo. 


\section{4 - Distância Genética}

As árvores construídas a partir dos valores de $F s t$, obtidos a partir de frequências haplotípicas dos dados de sequenciamento da HVS-I estão representadas nas Figuras 23, 24 e 25. As matrizes obtidas de valores de Fst podem ser visualizadas no Anexo I.

\section{Galvão}

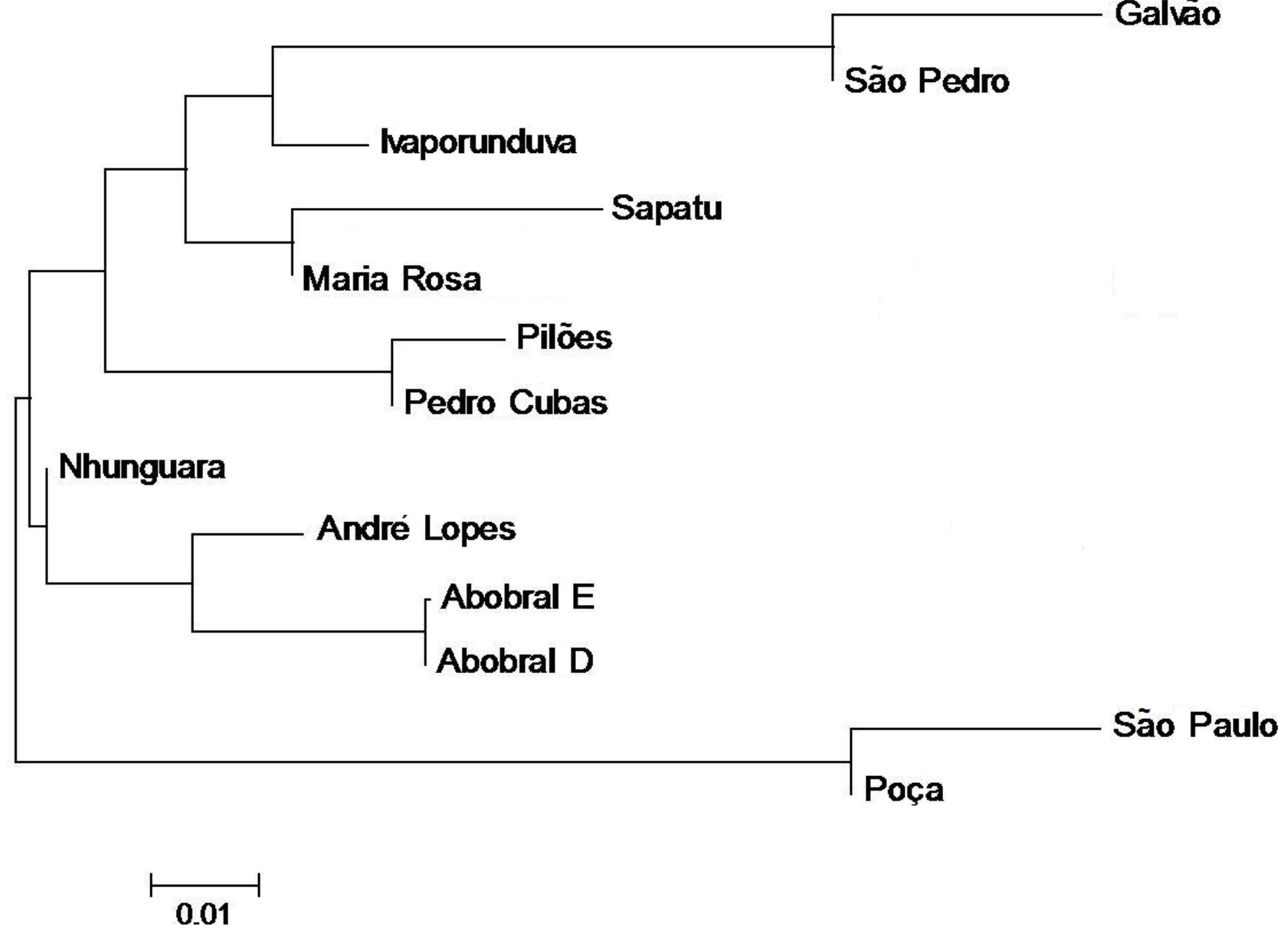

Figura 23 - Árvore das relações filogenéticas entre as comunidades remanescentes de quilombos do Vale do Ribeira e uma amostra da cidade de São Paulo com base na distância Fst entre as linhagens mitocondriais (Abobral D = Abobral Margem Direita; Abobral E = Abobral Margem Esquerda). 


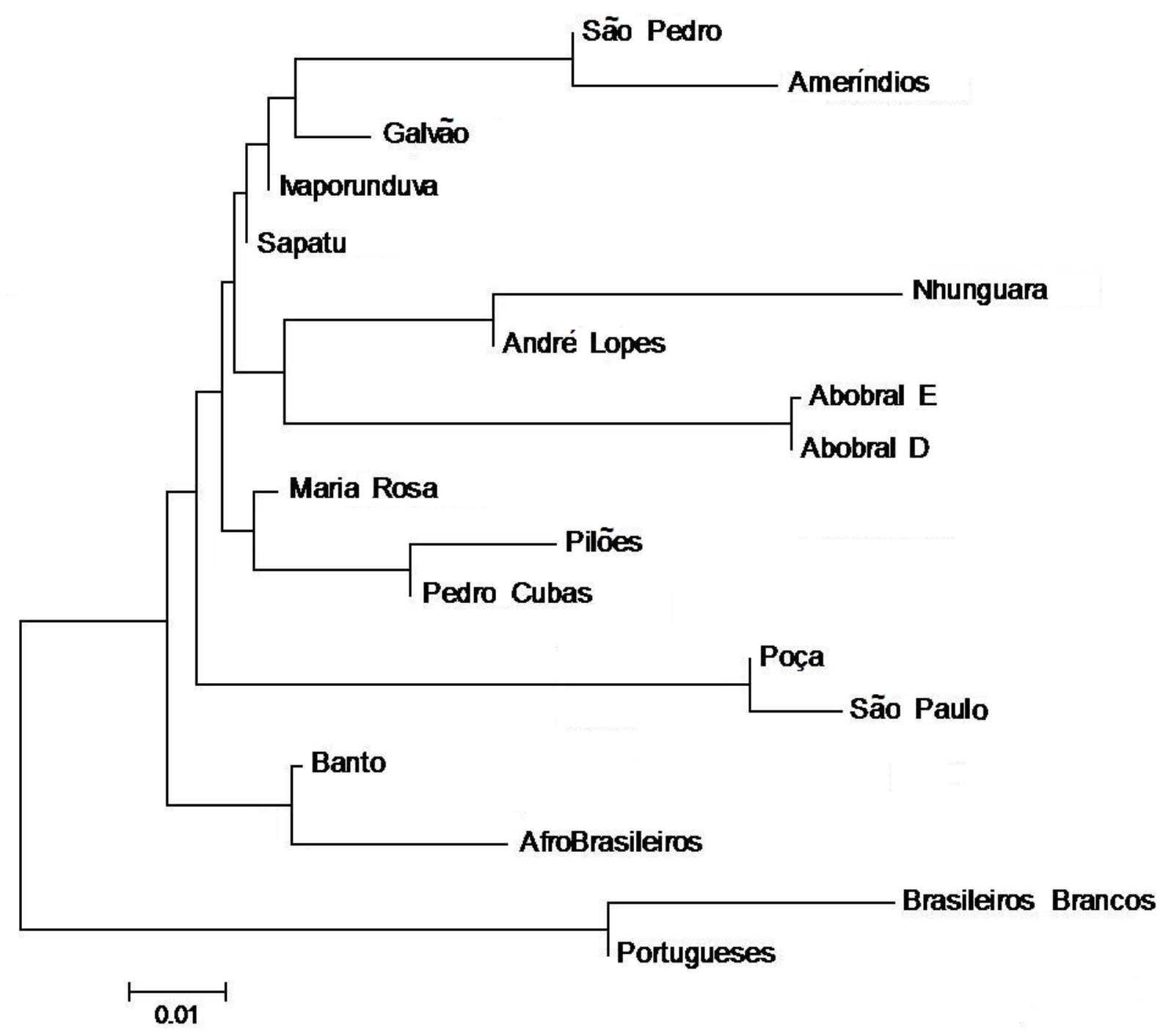

Figura 24 - Árvore das relações filogenéticas entre as comunidades remanescentes de quilombos do Vale do Ribeira, uma amostra da cidade de São Paulo e populações de referência com base na distância $F s t$ entre as linhagens mitocondriais. Como representantes de populações de referência da literatura foram selecionadas amostras dos bantos (Silva Jr. e col, 2006; Quintana-Murci e col, 2008), portugueses (Pereira e col, 2000), ameríndios (Marrero e col, 2007), afro-brasileiros (Bortolini e col, 1999; Ribeiro-dos-Santos e col, 2002; Silva Jr. e col, 2006; Hunemeier e col, 2007; Ribeiro-dos-Santos e col, 2007) e brasileiros brancos (Alves-Silva e col, 2000; Marrero e col, 2005). 


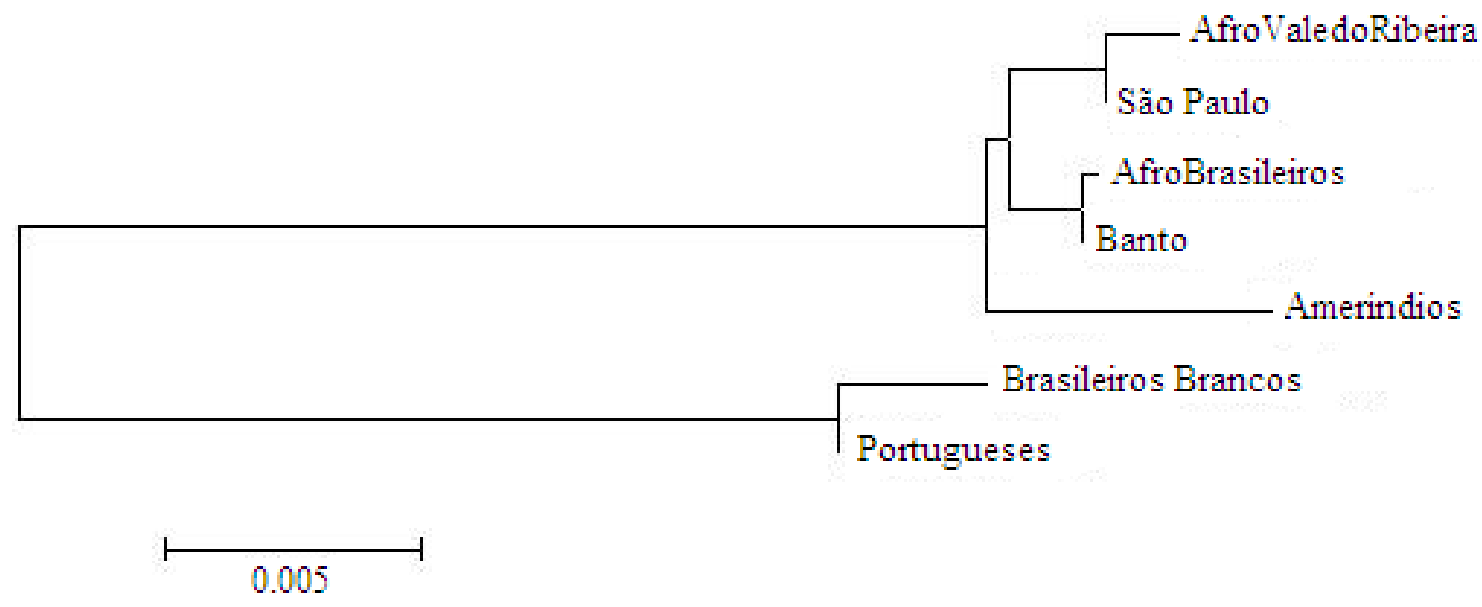

Figura 25 - Árvore das relações filogenéticas considerando os grandes grupos populacionais com base na distância $F s t$ entre as linhagens mitocondriais. Como representantes de populações de referência da literatura foram selecionadas amostras dos bantos (Silva Jr. e col, 2006; Quintana-Murci e col, 2008), portugueses (Pereira e col, 2000), ameríndios (Marrero e col, 2007), afro-brasileiros (Bortolini e col, 1999; Ribeiro-dos-Santos e col, 2002; Silva Jr. e col, 2006; Hunemeier e col, 2007; Ribeiro-dos-Santos e col, 2007) e brasileiros brancos (Alves-Silva e col, 2000; Marrero e col, 2005). 
5 - DISCUSSÃ̃ 


\section{5 - Discussão}

\section{1 - Frequência dos Haplogrupos Mitocondriais e Mistura Interétnica}

\subsection{1 - Populações Afro-Descendentes do Vale do Ribeira}

Os resultados globais obtidos nas comunidades remanescentes de quilombos são interessantes, pois indicam alta frequência de DNA mitocondrial ameríndio $(49,3 \%)$ e africano $(49,2 \%)$ e reduzida de haplogrupos europeus $(1,5 \%)$ em todas as doze populações (Tabela II).

Nas comunidades de Galvão, São Pedro e Ivaporunduva, detectamos as mais elevadas porcentagens de haplogrupos ameríndios. Um panorama ligeiramente distinto foi observado em Abobral Margem Direita, Abobral Margem Esquerda, Pilões, Nhunguara, Maria Rosa, André Lópes e Poça. Nestas comunidades, os haplogrupos africanos apresentaram porcentagens mais elevadas (valores superiores a 50\%). Nas comunidades restantes, de Sapatu e Pedro Cubas, a presença das linhagens mitocondriais foi equitativa, com aproximadamente $50 \%$ de contribuição para cada um dos dois grandes grupos étnicos (africanos e ameríndios). Haplogrupos europeus foram raramente detectados e estão presentes somente nas comunidades de Sapatu, André Lopes, Ivaporunduva e Poça (Tabela II).

A elevada frequência de DNAmt de origem ameríndia e africana nos quilombos não é um achado único: resultados semelhantes foram obtidos em quilombos da região amazônica, por exemplo, na população de Curiaú. A frequência de DNA mitocondrial africano foi de 53\%. A contribuição ameríndia foi também expressiva, atingindo $47 \%$ (Ribeiro-dos-Santos e col, 2002). Recentemente, 5 comunidades (Trombetas, Marajó, Pitimandeua, Tamauari e Mazagão) foram analisadas e detectou-se uma frequência de $50,2 \%$ de linhagens africanas e 46,6\% de linhagens ameríndias (Ribeiro dos Santos e col, 2007; Carvalho e col, 2008). Em três remanescentes de quilombos da região Nordeste (Mocambo, Riacho de Sacutiaba e Rio das Rãs) e um no Centro-Oeste do Brasil (Kalunga), a frequência de linhagens africanas foi maior, atingindo 85\%, seguida das linhagens ameríndias com frequência de 15\% (Brandão-Ferreira, 2006). Em 2006, Silva Jr. e col. analisaram o DNA mitocondrial de Cajueiro, outro remanescentes de quilombo da região Nordeste do Brasil, e encontraram uma contribuição africana de $70 \%$ e ameríndia de $30 \%$. 
No mesmo estudo, a comunidade de Cametá, quilombo da região Norte do Brasil, a contribuição africana foi de $40 \%$ e a ameríndia de $60 \%$.

Desde o início do tráfico negreiro para o Brasil, a região Nordeste do país foi uma importante entrada de negros africanos. Dois importantes portos de desembarque de escravos estavam localizados na Bahia e em Pernambuco. De acordo com os dados do IBGE em 2000, o Brasil tem a maior população negra fora da África sub-sahariana. Os negros e os pardos representam $45 \%$ da população brasileira. A maior concentração de afro-brasileiros dá-se na região Nordeste do país, especialmente no estado da Bahia, onde $80 \%$ da população é considerada de ascendência africana. Estes dados explicam a elevada frequência de material genético africano encontrado em populações de quilombos estudadas do Nordeste em relação às demais regiões do Brasil e pode também explicar a maior frequência de linhagens mitocondriais africanas nas comunidades afro-descendentes rurais da região central no trabalho de Brandão-Ferreira (2006), quando comparadas com os afrodescendentes rurais da região amazônica e do Vale do Ribeira, em São Paulo. A frequência de linhagens ameríndias detectadas em nosso trabalho se aproximou mais das observadas nos quilombos da Amazônia.

Diversos estudos com afro-descendentes urbanos de diversas regiões geográficas do Brasil detectaram uma baixa assimilação de linhagens ameríndias. A presença da fração ameríndia variou de nula em Ribeirão Preto até 11,7\% em São Paulo. A fração africana, por sua vez, atingiu valores superiores a 70\% (Bortolini e col, 1997; Silva Jr. e col, 2006; Hünemeier e col, 2007; Gonçalves e col, 2008). Estudos com afro-descendentes urbanos brasileiros, portanto, em contraste com as comunidades afro-descendentes rurais, sugerem baixa ocorrência de miscigenação interétnica com os indígenas.

Os escravos negros submetidos a precárias condições de vida e trabalho impostas pelos seus senhores fugiam das senzalas para a floresta. É muito provável que a sobrevivência em regiões desconhecidas para o negro africano e seu difícil acesso, locais típicos para o estabelecimento de um quilombo, tenha forçado o negro fugido a interagir com o indígena presente na região e dele aprendido a usufruir dos recursos locais para sua sobrevivência, como encontrar árvores frutíferas, animais para alimentação e rios que pudessem fornecer água e peixe (Azevedo e Castro, 1998; Bezerra-Neto, 2001). Essa interação pode explicar a miscigenação entre o homem africano e a mulher indígena, refletida nos dias de hoje pela 
elevada presença de linhagens mitocondriais ameríndias nos remanescentes de quilombos. Em comunidades urbanas, em contraste, o negro alforriado e mesmo o negro livre após a abolição do trabalho escravo, permaneceu estigmatizado e associado ao trabalho escravo, sem conseguir ocupar um melhor espaço na sociedade. As mulheres negras de uma maneira geral mantiveram seus trabalhos serviçais com salários reduzidos. Excluído e marginalizado da sociedade, o negro urbano interagiu menos com os demais grupos étnicos (www.saopaulo.sp.gov.br). Este fato pode, em parte, explicar a baixa assimilação detectada de linhagens ameríndias encontradas nas amostras urbanas, quando comparada aos quilombos.

\section{Fração Ameríndia}

Entre os afro-descendentes do Vale do Ribeira, as linhagens ameríndias mais frequentemente encontradas pertencem ao haplogrupo B $(29 \%)$, seguidas pelas linhagens do haplogrupo A (9\%), o haplogrupo C (8\%) e o menos freqüente, o haplogrupo D (4\%) (Tabela II). Na nossa amostra da cidade de São Paulo, o haplogrupo B também foi o mais frequente (12\%), seguidos pelos haplogrupos A e C (9\%) e o menos frequente, o haplogrupo D (4\%) (Tabela II).

Esse panorama é similar ao detectado na compilação de dados de Mendes-Júnior (2005), sobre a distribuição de frequências de haplogrupos indígenas no sudeste brasileiro. A distribuição indígena pode ajudar a explicar o padrão encontrado nos afro-descendentes do Vale do Ribeira e na cidade de São Paulo.

A distribuição dos haplogrupos mitocondriais em afro-descendentes rurais de outras regiões do Brasil apresenta um panorama diverso. Entre os afro-descendentes da Amazônia, na comunidade de Curiaú, o haplogrupo D foi o mais frequente, seguido do haplogrupo C e B e finalmente o A, menos frequente. (Ribeiro-dos-Santos e col, 2002). Nas 5 comunidades estudadas também da Região Amazônica (Trombetas, Marajó, Pitimandeua, Tamauari e Mazagão), as frequências detectadas dos haplogrupos A e C foram as mais elevadas, seguidas das dos haplogrupos B e D (Ribeiro-dos-Santos e col, 2007; Carvalho e col, 2008). Distribuição de frequências similar a essas foi identificada por Silva Jr. e col. (2006)

nas comunidades de Cametá e Trombetas, também na região Norte do Brasil. Em comunidades afro-descendentes do Nordeste e Centro-Oeste do país (Brandão-Ferreira, 
2006), o haplogrupo B foi o mais frequente, seguido pelo haplogrupo A, pelo haplogrupo C e finalmente o haplogrupo $\mathrm{D}$, menos frequente. Na comunidade de Cajueiro, também localizada no Nordeste, apenas o haplogrupo $\mathrm{C}$ foi identificado.

\section{Fração Africana}

Em relação às linhagens africanas, os afro-descendentes do Vale do Ribeira revelaram predomínio de linhagens do Macro-Haplogrupo L (L1 + L2) com uma frequência de 37\%, seguida das linhagens do haplogrupo L3 (12\%). Na amostra de São Paulo, o MacroHaplogrupo L atingiu uma frequência de $26 \%$ e o haplogrupo L3 uma frequência de $19 \%$. O haplogrupo L0 foi detectado com uma frequência de 5\%. No Vale do Ribeira nenhuma linhagem foi classificada como pertencente ao haplogrupo L0 (Tabela II).

Dados semelhantes foram encontrados nos remanescentes de quilombos da Amazônia e nos do Nordeste e Sul do Brasil (Bortolini e col, 1999; Ribeiro-dos-Santos e col, 2002; Silva Jr. e col, 2006; Ribeiro-dos-Santos e col, 2007; Carvalho e col, 2008). Em linhas gerais, o Macro-Haplogrupo L foi o mais frequente, seguido pelo haplogrupo L3 e, finalmente, o haplogrupo L0, com as frequências mais baixas.

Nos estudos com afro-brasileiros urbanos, panorama similar de distribuição de frequências entre os haplogrupos africanos é encontrado (Silva Jr. e col, 2006; Hünemeier e col, 2007; Gonçalves e col, 2008).

O haplogrupo L0 é encontrado principalmente nas regiões leste, sudeste e sul do continente africano (Gonder e col, 2007). Estas regiões africanas não são, segundo registros históricos, as fontes primárias de escravos africanos transportados para o Brasil. A baixa frequência desse haplogrupo no Brasil e sua eventual perda por deriva, podem explicar a ausência desse haplogrupo entre os remanescentes de quilombos do Vale do Ribeira. Em contrapartida, o Haplogroupo L1 é encontrado em elevada frequência na África centroocidental, o haplogrupo L2 possui uma distribuição ampla pela África subsaariana, mas encontra as mais elevadas frequências na região ocidental e sudeste do continente africano, distribuição similar à do haplogrupo L3 (Salas e col, 2002). Estas regiões, em especial a região centro-ocidental, segundo os registros históricos, foram importantes fontes de escravos para o território brasileiro (Klein, 2002), o que explica a elevada frequência do 
Macro-Haplogrupo L (L1 + L2) e haplogrupo L3 nos afro-brasileiros de uma maneira geral no Brasil e nos afro-descendentes do Vale do Ribeira.

\section{Fração Européia}

Haplogrupos mitocondriais europeus são pouco representados tanto nos quilombos da Região Sudeste de nossa amostra (1,5\%) (Tabela II) e da Região Amazônica do país (1,3\%) (Silva Jr. e col, 2006; Ribeiro-dos-Santos e col, 2007; Carvalho e col, 2008) como nos quilombos das regiões Nordeste e Centro-Oeste, onde estavam ausentes (Silva Jr. e col, 2006; Brandão-Ferreira, 2006).

Entre os indivíduos afro-brasileiros de populações urbanas, a representatividade de linhagens européias foi também baixa, mas as frequências foram superiores às das comunidades afro-brasileiras rurais. Em São Paulo, a contribuição européia foi estimada em 3\%, no Rio de Janeiro em 2\%, em Ribeirão Preto foi de 5\% e em Porto Alegre a estimativa foi de 8\% (Silva Jr. e col, 2006; Hünemeier e col, 2007; Gonçalves e col, 2008).

Apesar do número reduzido, a maioria dos haplogrupos europeus identificados em afro-brasileiros pertence ao haplogrupo $\mathrm{H}$, de ampla distribuição pela Europa ocidental (Torroni e col, 1998; Alves-Silva e col, 2000). Este fato condiz com os registros históricos sobre a origem dos europeus que aportaram em território brasileiro, com predominância dos portugueses.

\subsection{2 - População miscigenada da cidade de São Paulo}

Os resultados da amostra de São Paulo, descrita por alguns autores como uma população tri-híbrida, mostraram elevadas frequências de linhagens africanas (50\%), seguida das linhagens ameríndias (34\%) e européias (16\%) (Tabela II). De acordo com os critérios já mencionados de classificação dessa amostragem (Abreu-Silva, 2008), 61 indivíduos (59\%) foram classificados como brancos, 37 indivíduos (35\%) foram classificados como pardos, 4 indivíduos (3\%) foram classificados como negros e 2 indivíduos (2\%) foram classificados como indígenas.

Logo, certamente grande parte dos indivíduos que foram classificados como brancos por Abreu-Silva (2008) apresentam DNAmt africano ou indígena. Achados similares foram encontrados no estudo de Alves-Silva e col. (2000) com indivíduos classificados como 
brancos de cidades das diversas regiões do Brasil. Nesse trabalho, a contribuição genética global africana e ameríndia em indivíduos considerados brancos foi de, respectivamente, aproximadamente $30 \%$ e 30\%. Outro achado similar ocorreu no estudo de Marrero e col. (2005). Ao analisar 119 indivíduos oriundos de diversas localidades urbanas do Estado do Rio Grande do Sul, todos classificados como brancos, predominaram as linhagens européias. Entretanto, a frequência de linhagens ameríndias e africanas atingiram valores de, respectivamente, $36 \%$ e $16 \%$.

Estes dados indicam a natureza heterogênea das populacões brasileiras, mesmo quando classificadas como "brancas". Esse fenômeno é reflexo de uma história de prolongada e contínua de miscigenação diferenciada nas diferentes regiões do país. É retrato das particularidades históricas que podem gerar dissociação entre aparência física e ancestralidade.

Da mesma forma que os estudos com populações brancas urbanas brasileiras, os dados de populações brasileiras miscigenadas também refletem uma história de formação diversa entre as diferentes regiões do país. Foi constatado, por exemplo, um predomínio de linhagens africanas no Nordeste (Barbosa e col, 2008) e, em contraste, um predomínio de linhagens ameríndias na região da Amazônia (Santos e col, 1999; Marinho, 2004; Feio-dosSantos e col, 2006). Estes dados sugerem importante participação da mulher indígena na formação das comunidades urbanas miscigenadas na Região Norte do Brasil.

\section{2 - Redes de haplótipos}

No sub-haplogrupo L1b não foi observado nenhuma reticulação (Figura 10), diferentemente do sub-haplogrupo L1c, onde elas ocorreram (Figura 11). Reticulações foram observadas também nos haplogrupos L2 e L3 (Figuras 13 e 14). Em relação à fração ameríndia, todos os haplogrupos apresentaram redes livres de reticulações (Figuras 15, 16 e 17).

A análise da variabilidade haplotípica nos remanescentes de quilombos do Vale do Ribeira pela rede de haplótipos apresentou um claro padrão de divisão das linhagens ameríndias (A, B, C e D). O mesmo foi observado em relação às africanas (L1, L2 e L3) (ver Figuras 17 e 18), como esperado. 
A suspeita da presença de mutações fantasmas envolvidas em cada reticulação observada foi analisada de forma cuidadosa. Todas as mutações relacionadas com as formações prismáticas foram conferidas nos dados de sequenciamento, em cada amostra portadora de uma possível mutação fantasma. Além disso, todas as sequências foram realizadas em dois sentidos (forward e reverse) e as mutações estavam presentes em ambas as sequências. As linhagens deste trabalho estão, portanto, potencialmente livres de mutações fantasmas. A hipótese proposta para a presença dessas reticulações está relacionada a ocorrência de eventos de homoplasia, que ocorreram durante a evolução de cada linhagem. A ausência desse fenômeno nas linhagens ameríndias observada neste trabalho e sua presença nas africanas é provavelmente devida à história evolutiva mais recente das linhagens ameríndias, o que as torna menos provavelmente afetadas pelos fenômenos de homoplasia.

\section{3 - A Origem das sequências HVS-I dos Haplótipos Mitocondriais}

\section{Fração Ameríndia}

Em relação à investigação da HVS-I nos remanescentes de quilombos, 28 indivíduos foram classificados como pertencentes ao haplogrupo A, revelando 6 haplótipos diferentes (Tabela III; Figura 15). As transições 16319 e 16290 que praticamente definem este haplogrupo (Torroni e col, 1993) foram observadas em todos os haplótipos. A transição 16111, geralmente presente nas linhagens de nativos americanos do haplogrupo A e aparentemente ausente nas linhagens de amostras asiáticas (Horai e col, 1993; Torroni e col, 1993; Kolman e col, 1996; Yao e col, 2002) foi também observada em todos os haplótipos (ver Tabela II). No trabalho de Ward e col. (1996), ao analisarem amostras indígenas Xavante da comunidade Rio das Mortes e indígenas Tupi da comunidade Zoró (oriundos do Mato Grosso), e da comunidade Gavião (localizada em Rondônia), todas as 11 sequências classificadas como pertencentes ao haplogrupo A apresentaram as transições 16111, 16290 e 16319. Entretanto, Santos e col. (1996) não detectaram a transição 16111 em 5 amostras de ameríndios da Amazônia. Além disso, 2 amostras de indígenas da região Centro-Sul do Brasil no trabalho de Marrero e col. (2007) também não apresentaram essa transição. 
Um total de 122 indivíduos foram sequenciados e classificados como pertencentes ao haplogrupo B (Tabela III; Figura 15). Foram observados 7 haplótipos diferentes. Em todos eles, destacam-se a presença das transições 16189 e 16217, da deleção de 9pb e a ausência do sítio de restrição para a enzima $H p a I$ na posição 3592, marcadoras deste haplogrupo (Hertzberg e col, 1989; Torroni e col, 1993). Dois haplótipos do haplogrupo B claramente se destacam como predominantes nas populações de quilombos. O haplótipo mais frequente é definido pelas mutações nos nucleotídeos 16189, 16217, 16311 (HP12, Tabela III e Figura 15), detectado em 73 dos 122 indivíduos sequenciados com esse haplogrupo. O segundo haplótipo mais frequente é definido pelas mutações nos nucleotídeos 16189 e 16217 (HP09, Tabela III e Figura 15), detectado em 32 dos 122 indivíduos sequenciados. A frequência elevada do haplótipo HP12 é um forte indicativo de efeito do fundador na área.

O haplótipo HP12 é frequente nas comunidades de São Pedro e Galvão. Provavelmente herdado de uma única ou poucas mulheres ancestrais, é indicativo de uma origem genealógica comum para estas duas comunidades, o que combina com os relatos orais. Este haplótipo também ocorre em Ivaporunduva. Considerada a população mais antiga dos afrodescendentes do Vale do Ribeira e supostamente matriz das outras comunidades quilombolas, a presença significativa desse haplótipo na comunidade de Ivaporunduva e sua ampla distribuição por praticamente todas as comunidades estudadas reforça a hipótese de fundador. O haplótipo HP09 é outro haplótipo candidato a fundador. Este haplótipo foi detectado também em praticamente todas as comunidades afro-descendentes do Vale do Ribeira e foi o predominante entre as linhagens indígenas da comunidade de Sapatu.

No trabalho de Marrero e col. (2007), foram analisadas sequências mitocondriais de 278 indivíduos de tribos Guarani e Kaigang, localizadas no Mato Grosso do Sul, Paraná e Rio Grande do Sul. O haplogrupo B, muito frequentemente detectado no Vale do Ribeira, não foi identificado nos Guarani. Este dado contrasta com os resultados obtidos para as tribos Kaigang e com estudos da literatura com outras tribos da língua Tupi na América do Sul (eg. Schmitt e col, 2004; Dornelles e col, 2005; Ward e col, 1996; Bonatto e Salzano, 1997b), nas quais B ocorre com frequência. Este achado poderia indicar que a migração Tupi oriunda da região amazônica, provável origem dos Guarani, resultou na perda deste haplogrupo. Entretanto, mais estudos com os Guaranis são necessários para confirmar esta sugestão. 
Nos 78 indivíduos sequenciados do grupo Kaigang (Marrero e col, 2007), três indivíduos eram do haplogrupo B. Esse haplótipo (16189, 16217 e 16311) coincidiu com o haplótipo predominante encontrado nos indivíduos do haplogrupo B por nós estudados nos quilombos do Vale do Ribeira (HP12 da Tabela III e Figura 15). Em um estudo com 8 tribos indígenas da Amazônia de diversos grupos linguísticos, apenas 2 indivíduos de um total de 139 apresentaram a transição 16311. O haplótipo 16189, 16217 e 16311 foi identificado em uma única amostra (Santos e col, 1996). Nos outros estudos com afrodescendentes da região Amazônica, nenhum indivíduo do haplogrupo B apresentou a mutação 16311 por nós detectada no Vale do Ribeira (Ribeiro-dos-Santos e col, 2002; Ribeiro-dos-Santos e col, 2007; Carvalho e col, 2008) e nos Kaigang (Marrero e col, 2007). Este achado sugere a presença de mulheres indígenas Kaigang na formação das comunidades de quilombos do Vale do Ribeira. Registros históricos têm descrito um intenso movimento migratório dos Kaigang ao longo da costa sul e sudeste do Brasil em razão do contato com colonizadores não-ameríndios (Schmitz e Becker, 1997), o que poderia apoiar a sugestão do contato dos Kaigang com as populações afro-descendentes do Vale do Ribeira. Os Kaigang são reconhecidos como os descendentes dos nativos que habitavam o planalto centro-sul brasileiro em rústicas habitações subterrâneas. Seu número caiu drasticamente depois do contato com os colonizadores europeus. Hoje em dia vivem em reservas nos estados brasileiros do Rio Grande do Sul, Santa Catarina, Paraná e São Paulo.

Um total de 33 indivíduos sequenciados foram classificados como pertencentes ao haplogrupo C, revelando 9 haplótipos diferentes (Tabela III; Figura 16). O conjunto das transições 16298, 16325 e 16327 é característico do haplogrupo (Hertzberg e col, 1989; Torroni e col, 1993), foi observado, como esperado, em todos os haplótipos. O haplótipo HP14 (16051, 16172, 16223, 16295, 16298, 16311, 16325, 16327, 16335) foi o mais frequente, ocorrendo em 12 dos 33 indivíduos sequenciados. No trabalho de Marrero e col (2007) este foi também o haplótipo mais frequente entre amostras de indígenas Kaigang, encontrado em 19 indivíduos de um total de 36 sequenciados. Este haplótipo não ocorreu nas amostras Guarani. Este dado torna mais convincente a hipótese da contribuição dos Kaigang nos quilombos do Vale do Ribeira. Este haplótipo (HP14) não havia sido detectado em trabalhos anteriores no qual foram analisadas a HVS-I de 82 indivíduos 
indígenas das tribos Xavante (falantes do idioma Gê), Zoró (falantes do idioma Tupi) localizadas no Mato-Grosso, e Gavião (grupo Tupi-Mondé) localizados em Rondônia (Ward e col, 1996), e a HVS-I de 139 indivíduos indígenas de 8 tribos de diversos grupos linguísticos da região Amazônica, no segundo estudo (Santos e col, 1996).

O haplogrupo D foi observado em 9 amostras sequenciadas, revelando 5 haplótipos diferentes (Tabela III; Figura 16). A transição 16325 encontrada em linhagens de nativos americanos, foi observada em todos os haplótipos. Ela ocorre nas linhagens D do continente asiático. Outras transições, descritas anteriormente em populações ameríndias, encontram-se também presentes nas amostras do Vale do Ribeira: 16223, 16295, 16362 (Torroni e col, 1993; Ward e col, 1993; Torroni e col, 1993; Santos e col; 1996). Este haplogrupo foi o menos frequente nos remanescentes de quilombos do Vale do Ribeira, presente apenas em 4 das 11 comunidades (Sapatu, Ivaporunduva, Pedro Cubas, André Lópes e Poça) (Tabela II). O haplogrupo D não foi detectado nos indígenas Kaigang (Marrero e col, 2007). Em nossas amostras afro-descendentes do Vale do Ribeira, um dos haplótipos do haplogrupo D (HP 24: 16223, 16325, 16362) foi também detectado nas amostras indígenas Guarani descritas no trabalho de Marrero e col. (2007), mas nunca havia sido detectado antes. Estes dados sugerem também ter ocorrido interação entre os quilombos do Vale do Ribeira com indígenas Guarani.

\section{Fração Africana}

Cerca de 97 indivíduos sequenciados foram classificados como pertencentes ao haplogrupo L1, revelando 24 haplótipos diferentes (Tabela III; Figura 12).

O sequenciamento revelou que o sub-haplogrupo L1c, em especial, destaca-se por sua elevada frequência nos afro-descendentes do Vale do Ribeira e por ser o mais frequente entre todas as linhagens mitocondriais africanas (Tabela II). Do total de 90 diferentes haplótipos mitocondriais (africanos, ameríndios e europeus) identificados no Vale do Ribeira, 17 haplótipos foram classificados como pertencentes ao sub-haplogrupo L1c (Tabela III; Figura 11). Em Abobral Margem Esquerda, o haplótipo HP29 (L1c) é o mais numeroso, o que nos leva a sugerir este haplótipo como um fundador nessa comunidade.

Detectamos também nos indivíduos pertencentes ao sub-haplogrupo L1c, uma linhagem classificada como L1c3, nunca antes descrita em populações brasileiras (ver haplótipos 
HP40 e HP41 da Tabela III; Figura 11). Este pode ser um indicativo interessante de componentes africanos ainda não detectados que contribuíram para o pool gênico dos brasileiros atuais.

O sub-haplogrupo L1c foi inicialmente definido por Rando e col. (1998) sendo caracterizado pelas transições $(16129,16187,16189,16223,16294,16311,16360)$, pela presença de um sítio de restrição para a enzima TaqI na posição 9070 e para a enzima RsaI na posição 12810. Estudos indicaram que o sub-haplogrupo L1c ocorre em elevadas frequências na África Centro-Ocidental (Batini e col, 2006; Watson e col, 1997; Rando e col, 1998; Krings e col, 1999; Green e col, 2000; Salas e col, 2002; Fadhlaoui-Zid e col, 2004; Salas e col, 2004; Beleza e col, 2005). Estudos realizados com afro-descendentes no continente americano indicam que o sub-haplogrupo L1c apresenta as frequências mais elevadas na América do Sul (Batini e col, 2006). O haplogrupo L1c, juntamente com L0a1, L3e1 e L3e2, foi descrito como apresentando elevadas frequências entre afro-descendentes de diversas regiões do Brasil (Alves-Silva e col, 2000; Silva Jr. e col, 2006). O grupo de Alves-Silva e col. (2000) sugeriu que Angola poderia ser a origem das linhagens de L1c detectadas no Brasil, uma vez que foi este país a principal fonte de escravos que aportaram em terras brasileiras. Esta hipótese é apoiada por estudos realizados com populações Banto de Angola (Mbundu, Bakongo e Cabinda) por Plaza e col. (2004) e Beleza e col. (2005), que observaram nessas populações elevadas frequências do sub-haplogrupo L1c. Estes fatos sugerem ascendência Banto e angolana para os afro-descendentes do Vale-do-Ribeira. O mesmo foi observado pelo nosso grupo de pesquisa em relação aos haplótipos relacionados à mutação que causa anemia falciforme (Auricchio e col, 2007) nos mesmos quilombos, nos quais o haplótipo Banto foi o mais frequentemente encontrado em ligação com a mutação HbS.

Em um extenso estudo de revisão filogenética do sub-haplogrupo L1c realizado por Batini e col. (2006) foram compilados dados da literatura de sequências mitocondriais de HVS-I e HVS-II africanas e afro-americanas e uma reclassificação para o haplogrupo L1c foi proposta em relação à anterior de Salas e col. (2002). Foi sugerido nessa nova classificação que a linhagem por nós detectada e nomeada como L1c3 fosse incluída na L1c1b. Entretanto, o estudo manteve a sugestão de uma origem a partir dos Bantos para essa linhagem. 
A provável origem geográfica centro-ocidental Africana para o pool gênico dos afrodescendentes do Vale do Ribeira, sugerida neste trabalho, coincide com as inferências realizadas nos estudos de origens geográficas de DNA mitocondrial em populações afrodescendentes urbanas estudadas pelo grupo de pesquisa de Gonçalves e col. (2008) com 120 indivíduos afro-descendentes da cidade de São Paulo. A maioria das amostras (102) apresentou linhagens africanas características da região subsaariana, como por exemplo, os haplogrupos L0a, L1c1, L2a, L2a1 e L3e2 . As análises mais detalhadas de origem, utilizando dados da literatura de populações nativo-africanas, mostraram uma elevada contribuição genética ancestral africana oriunda principalmente das regiões da África centro-ocidental (Angola, Fang, Cabinda, Bakaka e Bassa) representada, por exemplo, pelos haplogrupos L1b, L1c, L2a1 e L3e, seguida da África Ocidental (Kanuri, Yoruba, Senegal, Serer, Wolof, Mandenka, Mende, Loko, Limba, Temne, Guiné-Bissau e Hause) representada, por exemplo, pelos haplogrupos L1b, L2, L3b, L3d. Uma contribuição genética africana menos frequente foi identificada em relação à região da África Oriental (Moçambique) representada, por exemplo, pelos haplogrupos L1a, L3f e L3g. Dados similares foram encontrados em outros estudos com afro-descendentes oriundos das cidades do Rio de Janeiro, Porto Alegre e Ribeirão Preto (Silva Jr. e col, 2006; Hünemeier e col, 2007).

Em resumo, tantos os nossos achados como os da literatura podem ser explicados por dados históricos, que, apesar de incompletos, apontam para uma significativa importância das regiões da África Centro-Ocidental (Angola, Cabinda, Congo) e da África Ocidental (Senegâmbia, Benin, Biafra e Serra Leoa) como origem dos escravos africanos que aportaram em terras brasileiras entre os anos de 1777 e 1888 (Klein, 2002). Outros dados históricos revelaram uma fonte secundária, mas significativa, de africanos oriundos da África Oriental (Moçambique). (Florentino, 1997; Alpers, 1997).

Dois indivíduos, ambos da comunidade de São Pedro, apresentaram além do sítio de restrição característico do Macro-Haplogruplo L (L1 + L2), a deleção de 9pb (haplótipo HP46 da Tabela III). Dados da literatura apontam que a deleção, marcadora do haplogrupo B, presente em populações ameríndias e asiáticas, foi também detectada em baixas frequências em algumas linhagens de populações africanas (Plaza e col, 2004). 
O haplogrupo L2 foi identificado em 49 indíviduos sequenciados, apresentando 13 diferentes haplótipos (Tabela III; Figura 15). Na comunidade de Pilões, o haplogrupo L2 se destaca como o mais frequente de todos (Tabela II). Os dados de sequenciamento revelaram o haplótipo HP56 (Tabela III) como o mais frequente. Este haplótipo pode ser, portanto, considerado como candidato a fundador da comunidade de Pilões. A transição que esteve presente em todas as amostras sequenciadas deste haplogrupo, a 16278, é considerada na literatura como marcadora do grupo. Entretanto, não é exclusiva. O sub-haplogrupo L2a, considerado um dos marcadores representativos dos Bantos (Bandelt e col, 1995; Watson e col, 1997; Alves-Silva e col, 2000) ocorreu em 22 dos 49 indivíduos sequenciados no nosso estudo com esse haplogrupo. Esses dados convergem com os dados de sub-haplogrupo L1c ao apontar uma provável ascendência dos Bantos nos quilombos do Vale do Ribeira. Diversos outros trabalhos com nativos africanos confirmam a ampla distribuição do haplogrupo L2a no continente africano, com predomínio na região Sudeste do continente (Salas e col, 2004). Em Angola, a frequiência atingiu 25\% (Plaza e col, 2004) e em Moçambique, 44\% (Pereira e col, 2001). É possível que uma fração dos L2a nos quilombos tenha vindo da região de Moçambique.

Finalmente, 51 indivíduos sequenciados foram classificados como pertencentes ao haplogrupo L3, revelando 16 haplótipos diferentes (Tabela III; Figura 16). O haplótipo HP77 (16223, 16311 e 16320) se revelou predominante, detectado em 28 dos 51 indivíduos sequenciados. Dentre os 16 haplótipos detectados, 13 foram classificados como pertencentes ao sub-haplogrupo L3e2. Este sub-haplogrupo já foi descrito como frequente em afro-descendentes brasileiros de diversas regiões do Brasil (Alves-Silva e col, 2000; Silva-Júnior e col, 2006). L3e2 é considerado como outro marcador representativo dos Bantos (Bandelt e col, 1995; Watson e col, 1997; Alves-Silva e col, 2000) e esses achados novamente corroboram a ascendência dos Bantos nos quilombos do Vale do Ribeira, como sugerido pelas análises dos sub-haplogrupos L1c e L2a.

Dados da literatura com nativos africanos apontam incidência mais elevada do haplogrupo L3e na região Centro-Oeste africana. Sua frequência também é significativa no Oeste e Sudeste do continente africano. Entretanto, é baixa no sul, leste e norte da África (Salas e col, 2004). Em Angola este haplogrupo registrou frequência de 20,5\% (Plaza e col, 2004) e atingiu 17,4\% em Moçambique (Pereira e col, 2001). 
Em resumo, a presença de DNA mitocondrial das linhagens L1c, L2a e L3e apontam para as regiões Oeste, Centro-Oeste e Sudeste da África como principal origem do material genético africano encontrado nos remenescentes de quilombos do Vale do Ribeira. Porém, não excluem alguma contribuição de linhagens oriundas de Moçambique. Estes dados são compatíveis com os relatos históricos que se referem a estas regiões como as que mais forneceram escravos durante o período do tráfico da África para o Brasil (Florentino, 1997; Alpers, 1997; Anjos, 2000; Vainfas, 2000; Klein, 2002).

\section{Fração Européia}

Somente 6 linhagens foram identificados como européias: duas do haplogrupo J, uma do haplogrupo K, um indivíduo do haplogrupo T e dois do haplogrupo H (Tabela III). A pequena assimilação de linhagens européias nos remanescentes de quilombos do Vale do Ribeira foi também encontrada em outros trabalhos com afro-descendentes brasileiros (Ribeiro-dos-Santos e col, 2002; Brandão-Ferreira, 2006; Ribeiro-dos-Santos e col, 2007; Carvalho e col, 2008).

\section{4 - Estimativas de Diversidade Genética.}

\subsection{1 - Diversidade haplotípica e nucleotídica}

\section{Fração ameríndia nos afro-descendentes do Vale do Ribeira}

A Tabela VI apresenta a comparação dos dados de diversidade nucleotídica ameríndia nos afro-descendentes do Vale do Ribeira com os dados sobre indígenas da literatura.

Quanto à diversidade nucleotídica, a fração ameríndia dos remanescentes de quilombos do Vale do Ribeira apresentou valores mais baixos de diversidade do que os observados em tribos indígenas da Amazônia (Ward e col, 1996; Santos e col, 1996). Já em relação a indígenas do Centro-sul do Brasil, a fração ameríndia nos afro-descendentes do Vale do Ribeira apresentou valores de diversidade superiores às comunidades Guarani e valores inferiores aos das comunidades Kaigang (Marrero e col, 2007). A comparação com demais tribos Tupi e Jê, incluindo dados de indígenas da América do Sul, revelou que os valores de 
diversidade nucleotídica da fração ameríndia dos afro-descendentes do Vale do Ribeira foram superiores (Marrero e col, 2007).

Tabela VI - Estimativas de diversidade nucleotídica do DNA mitocondrial em populações indígenas e na fração ameríndia de afro-descendentes do Vale do Ribeira.

\begin{tabular}{lcl}
\hline \multicolumn{1}{c}{ Populações } & $\boldsymbol{\pi}$ & \multicolumn{1}{c}{ Referências } \\
\hline Afro-descendentes Vale do Ribeira & 0.0129 & Presente estudo \\
Ameríndios da Amazônia & 0,0131 & Ward e col, 1996; Santos e col, 1996 \\
Guarani & 0,0067 & Marrero e col, 2007 \\
Kaigang & 0,0171 & Marrero e col, 2007 \\
Outros Tupi & 0,0423 & Marrero e col, 2007 \\
Outros Jê & 0,0379 & Marrero e col, 2007 \\
\hline
\end{tabular}

$\pi$ : diversidade nucleotídica.

A região do Vale do Ribeira foi marcada pela presença indígena Guarani. As comunidades indígenas do Vale do Ribeira hoje são formadas por dez aldeias Guaranis de famílias pertencentes aos subgrupos Mbyá e Ñandeva. Os indios Guarani pertencem à família linguística Tupi e a teoria mais aceita sobre o local de origem dessa família é a região Amazônica. Uma de suas rotas de dispersão teria sido em direção a regiões mais ao sul do Brasil (Carneiro e Cunha, 1998). Durante essa dispersão, supõe-se que teriam sofrido grave efeito de gargalo e queda de diversidade genética, fato confirmado nos indivíduos do grupo Guarani atuais pelo baixo valor de diversidade nucleotídica (Marrero e col, 2007). Os indígenas Kaigang pertencem a família linguistica Jê e seu provável local de origem situase no Nordeste do Brasil, entre os rios São Francisco e Tocantins. Grupos dessa família linguística teriam também migrado para localidades mais ao sul do Brasil, dando origem aos Kaigang (Urban, 1998). Não há evidências de forte efeito gargalo com os Kaigang (Urban, 1998), o que explica seus índices de diversidade mais elevados em relação aos Guarani.

Como os índices de diversidade genética das amostras de quilombos do Vale do Ribeira mostraram valores intermediários entre os grupos Guarani e Kaigang, podemos especular que ocorreu mistura de mulheres de ambos grupos indígenas na formação dos quilombos do Vale do Ribeira. Essa especulação tem sentido se considerarmos a discussão da origem das sequências observadas (ver item 5.3 na página 87 ). 


\section{Fração africana dos afro-descendentes do Vale do Ribeira}

O conjunto de matrilinhagens africanas, observadas nas populações afro-descendentes do Vale do Ribeira apresentou elevados valores nas estimativas de diversidade haplotípica. Nesta análise, comparamos a média das diferenças nucleotídicas (k) e os resultados de diversidade haplotípica (Hd) entre o estoque africano no Vale do Ribeira com os estoques de linhagens mitocondriais de diversas regiões do continente africano. Foram observados valores próximos entre os dois grupos amostrais (Tabela VII).

Tabela VII - Estimativas de diversidades genéticas, representadas pelas estimativas de diversidade haplotípica $(\mathrm{Hd})$ e média das diferenças nucleotídicas $(\mathrm{k})$, em populações do continente africano e no estoque de linhagens africanas nos afro-descendentes do Vale do Ribeira.

\begin{tabular}{lccl}
\hline \multicolumn{1}{c}{ Populações } & Hd & k & \multicolumn{1}{c}{ Ref. } \\
\hline Norte da África & 0.975 & 5.10 & Salas e col, 2004 \\
Oeste da África & 0.988 & 6.60 & Salas e col, 2004 \\
Centro-Oeste da África & 0.987 & 8.70 & Salas e col, 2004 \\
Leste da África & 0.994 & 8.00 & Salas e col, 2004 \\
Sudeste da África & 0.964 & 8.40 & Salas e col, 2004 \\
Sul da África & 0.925 & 7.90 & Salas e col, 2004 \\
\hline Média Africana & $\mathbf{0 . 9 7 2}$ & $\mathbf{7 . 4 5}$ & Salas e col, 2004 \\
Afro-descendentes Vale do Ribeira & $\mathbf{0 . 9 5 1}$ & $\mathbf{8 . 9 4}$ & Presente estudo \\
Afro-descendentes da Amazônia & $\mathbf{0 . 9 8 4}$ & $\mathbf{7 . 6 6}$ & Carvalho e col, 2008 \\
\hline
\end{tabular}

Hd: diversidade haplotípica; k: média das diferenças nucleotídicas.

Durante o tráfico negreiro para o Brasil, muitos navios levavam cerca de três a seis meses nos portos da África para completar uma carga de cerca de 400 escravos. Isto resultou em grupos de escravos muito heterogêneos, com africanos de várias nações em um único navio. Era inclusive a prática dos comerciantes misturar negros que não falassem o mesmo idioma, ainda no porto de origem, de modo a aumentar a segurança e desencorajar eventuais levantes ou insubordinações. Além disso, no Brasil, os escravos africanos passaram por processos de migrações internas, como remanejamento de mão-de-obra para agricultura e pecuária em diferentes regiões do país. Este remanejamento foi especialmente intenso após o bloqueio naval inglês contra o tráfico atlântico (Florentino, 1997; Klein, 
2002). Como resultado, a literatura sobre índices de diversidade nos afro-brasileiros indicam que eles mantiveram de forma significativa a variabilidade genética do continente africano. Este fato pode explicar os valores similares de diversidade genética observados, nas linhagens mitocondriais, entre os afro-brasileiros nos quilombos e as populações africanas.

\section{Comunidades Afro-descendentes do Vale do Ribeira}

Os índices de diversidade haplotípica variaram de 0,7701 a 0,9524 nas populações completas dos afro-descendentes do Vale do Ribeira. Em São Paulo, esse valor correspondeu a 0,9862. Devido à composição mais heterogênea da população da cidade de São Paulo, é esperado um valor superior de diversidade genética. O compartilhamento de haplótipos entre a amostra de São Paulo e as comunidades afro-descendentes do Vale do Ribeira foi, entretanto, considerável. Aproximadamente 52\% dos haplótipos mitocondriais detectados em São Paulo ocorreram também no Vale do Ribeira (ver Tabela IV).

Em linhas gerais, os valores de diversidade genética entre as doze comunidades afrodescendentes do Vale do Ribeira foram muito similares entre si (Tabela V). Esta aparente homogeneidade genética entre as comunidades afro-descendentes do Vale do Ribeira pode ser explicada pelo processo geral de ocupação da área pelos escravos africanos e seus descendentes.

De acordo com alguns registros, a ocupação da região foi marcada por intensa mobilidade geográfica, que caracterizou a extração de ouro de lavagem e absorção expressiva de mão-de-obra escrava acompanhada por pequenas roças de subsistência. A população negra que se manteve livre durante o período escravista ocupou o Vale do Ribeira como uma extensa área de continuidade geográfica. Os relatos indicam, ainda, que os casamentos eram uma maneira de garantir acesso a terra e, através da descendência, estabelecer novos núcleos (Paes, 2009). Muitos desses casamentos devem ter ocorrido com mulheres indígenas. Essa característica geral de ocupação pode explicar os valores similares encontrados de diversidade genética entre as doze comunidades estudadas neste presente estudo, já que não é incomum encontrar relações de parentesco entre as diferentes comunidades afro-descendentes do Vale do Ribeira. Em outras palavras, há continuidade geográfica e genealógica entre essas populações. 


\subsection{2 - Diferenças par-a-par}

Neste trabalho, as análises de distribuição das diferenças par-a-par (Figuras 21, 22, 23 e 24) representam uma forma complementar de representação da diversidade genética nos quilombos do Vale do Ribeira. Apesar dessa análise também fornecer indícios sobre a história demográfica, essa interpretação demográfica deve ser encarada com cautela nos remanescentes de quilombos. A distribuição em forma de sino ou unimodal (que se assemelha à distribuição normal), observada nas análises realizadas, a princípio poderia ser resultado de episódios de expansão populacional a partir de um número reduzido de haplótipos mitocondriais nos afro-descendentes do Vale do Ribeira. Esta expansão de fato pode ter ocorrido nas populações, usualmente fundadas por pequenos grupos. Entretanto, como se tratam de comunidades cuja formação provém do amalgamento de populações parentais pré-existentes (ameríndios, africanos e europeus), a inferência demográfica pode na verdade representar um fenômeno ocorrido nas populações parentais e não exclusivamente nas comunidades afro-descendentes do Vale do Ribeira. Da mesma forma, o teste D de Tajima é capaz de detectar desvios nas frequências esperadas de sítios segregantes sob a teoria da neutralidade. Entretanto, o teste não é capaz de discenir entre as causas demográficas ou relacionadas à seleção para os desvios identificados. Se considerarmos a região HVS-I do DNAmt como uma sequência livre de seleção, os valores obtidos neste caso são também indicativos de eventos demográficos nas populações avaliadas. Os testes de Tajima se mostraram todos negativos, com valores de $P$ significativos $(\mathrm{P}>0,05)$, sugestivo de eventos de expansão populacional.

Por outro lado, ocorreu a formação de um segundo pico na distribuição das diferenças par-a-par na posição que corresponde a zero (Figura 22) no estoque ameríndio das linhagens mitocondriais encontradas nos afro-descendentes do Vale do Ribeira. Certamente esse fenômeno é resultado de um episódio demográfico ocorrido na região após a fundação dos quilombos. Estudos similares realizados com diversas populações ameríndias do continente americano mostraram que a curva da distribuição das diferenças par-a-par, quando avaliada por haplogrupo, frequentemente apresenta uma distribuição unimodal. Este dado indica que cada haplogrupo ameríndio pode ter passado por um grande episódio de expansão após sua chegada no continente americano. Entretanto, quando a análise é realizada para as tribos indígenas americanas, frequentemente a distribuição resultante é 
bimodal. Isto sugere, neste caso, que esses grupos humanos possam ter sofrido pelo menos dois episódios de expansão desde que as populações ancestrais chegaram inicialmente no novo mundo (Slatkin e Hudson, 1991; Bonatto e Salzano, 1997; Schurr, 2004; Schurr e Sherry, 2004). Certamente, ao longo das migrações internas pelo continente americano, as populações ameríndias passaram por episódios demográficos diversos, com pelo menos mais de um evento de efeito gargalo seguido de expansão populacional.

A fração de linhagens ameríndia nos quilombos é resultado de processos de interação entre quilombolas e indígenas que viviam no local, além de efeitos da história genealógica posterior. Episódios demográficos resultantes do contato ou após esses contatos podem provocar efeitos perceptíveis locais, posteriores aos que ocorreram com a população parental, nas análises de distribuição das diferenças par-a-par. Um determinado haplótipo pertencente ao haplogrupo B (ver HP12, Tabela III e Figura 15) apresenta frequência elevada e distribuição ampla entre as comunidades afro-descendentes do Vale do Ribeira. Esta frequência elevada e ampla do haplótipo é um forte indicativo de efeito fundador na área, provavelmente herdado de uma única ou poucas mulheres ancestrais. A análise da distribuição das diferenças par-a-par (a presença de um segundo pico, na Figura 2) na fração ameríndia dos afro-descendentes do Vale do Ribeira provavelmente é resultado do efeito do fundador do haplótipo HP12, pertencente ao haplogrupo B. Vale a pena destacar mais uma vez que esse haplótipo (HP12), esteve ausente e em baixa frequência, respectivamente, em tribos Guarani e Kaigang, localizadas no centro-sul do Brasil, próximas da região do Vale do Ribeira. Estes achados reforçam a idéia de um efeito demográfico localizado e específico para o haplogrupo B e que poderia explicar a distribuição bimodal das diferenças par-a-par observada na fração ameríndia. Além disso, efeito semelhante não foi observado nos diferenças par-a-par estudadas em relação à fração dos haplogrupos africanos.

\section{5 - Distância Genética}

Foram construídos dendrogramas a partir dos valores de Fst calculados com base nas frequências haplotípicas obtidas pelo sequenciamento da HVS-I. 
Estas filogenias (Figuras 23, 24 e 25), em conjunto com dados históricos existentes, permitem recontar parte da história materna das comunidades remanescentes de quilombos do Vale do Ribeira. No que se refere à história dos escravos africanos e seus descendentes na região do Vale do Ribeira, as informações disponíveis foram compiladas de algumas fontes, em especial de Almeida (1955), Careno (1997), Andrade (2000) e Oliveira Jr. e col. (2000). As informações sobre possíveis haplótipos fundadores nas comunidades serão novamente discutidas na medida que forem pertinentes às inferências históricas.

No dendrograma que inclui as comunidades afro-descendentes do Vale do Ribeira e a amostra de São Paulo (Figura 23) e no dendrograma que inclui informações sobre populações da literatura (Figura 24), as populações de São Pedro e Galvão aparecem próximas, partindo de um mesmo nó. Este fato condiz com a pequena distância geográfica entre essas duas comunidades. Relatos históricos apontam a história de São Pedro como intimamente ligada à de Galvão. Ambas formavam um único grupo de parentesco, ocupando um território inicialmente contínuo. O início do povoamento dessa área data de 1833, com a chegada de Bernardo Machado dos Santos, juntamente com mais ou menos 8 mulheres e 4 homens, os primeiros habitantes de São Pedro. Eram escravos fugidos de uma mesma fazenda. Por causa das perseguições que sofria, Bernardo trocou seu nome para Bernardo Furquim de França. A construção das genealogias das duas comunidades atesta para essa origem comum. Muitas foram as relações de parentesco detectadas entre os indivíduos das duas populações.

Bernardo Furquim é uma figura importante nessa região. Segundo os moradores, Bernardo Furquim teve pelo menos duas mulheres diferentes, tendo com elas cerca de 24 filhos (nem todos os nascimentos foram registrados). Esses filhos teriam se espalhado pela região e contribuído para a fundação de outras comunidades.

No trabalho de Cotrim e col (2004), onde se investigaram marcadores moleculares autossômicos do tipo inserção de Alu em parte das comunidades afro-descendentes do Vale do Ribeira estudadas no presente estudo, Galvão e São Pedro também aparecem como comunidades próximas entre si. Situação similar foi observada no trabalho de MacedoSouza (2003) que também estudou parte das comunidades afro-descendentes do Vale do Ribeira em relação a marcadores moleculares do cromossomo Y. 
No presente trabalho, as comunidades de São Pedro e Galvão se aproximam mais dos ameríndios do que das populações da etnia dos Bantos, fato distinto do observado pelas análises de cromossomo $\mathrm{Y}$ e de inserções de Alu. As linhagens mitocondriais ameríndias em Galvão e São Pedro são frequentes (Tabela II) e chegam a atingir frequências superiores a $70 \%$ do total. Essa alta frequência de DNA mitocondrial indígena certamente provocou a aproximação maior com os grupos ameríndios, aqui representados por amostras de referência Guarani e Kaigang (Figura 24).

Nossos dados permitiram identificar um haplótipo candidato (HP12, Tabela III; Figura 15) a fundador para as comunidades de Galvão e São Pedro. É provável que seja o haplótipo de pelo menos uma das mulheres de Bernardo Furquim, como indicou a análise genealógica realizada pela nossa equipe e principalmente nos relatos colhidos nas comunidades de André Lopes e Ivaporunduva. Este haplótipo está presente em quase todos os remanescentes de quilombos do Vale do Ribeira e é especialmente frequente nas comunidades de Galvão e São Pedro. Certamente o efeito do fundador provocado pelo grande número de filhos das mulheres de Bernardo Furquim pode explicar a frequência observada do haplótipo HP12 entre os afro-descendentes do Vale do Ribeira. Nos estudos com marcadores de cromossomo Y, o estudo genealógico revelou um haplótipo de origem européia para Bernardo Furquim (Macedo-Souza, 2003). Esses achados permitem algumas especulações: filho bastardo de uma relação entre um senhor de escravos com uma escrava africana, Bernardo Furquim fugiu e se estabeleceu na atual região de São Pedro. O local pode pode ter coincidido com um assentamento temporário indígena, provavelmente Kaigang, o que teria favorecido a interação com as mulheres indígenas no local. Deve ser essa a origem étnica de pelos menos uma das mulheres de Bernardo Furquim, de acordo com o haplótipo mitocondrial candidato. Histórias semelhantes à de Bernardo Furquim explicariam os resultados gerais obtidos pelas análises de DNA mitocondrial e de cromossomo Y, ou seja, explicariam a elevada frequência de material genético europeu detectado pelas análises de cromossomo Y (não detectado no DNA mitocondrial) e presença frequente de material genético indígena nas análises mitocondriais, não observada nas análises do cromossomo $\mathrm{Y}$.

Esse achado é coerente com a história de formação do povo brasileiro, em que se sabe que os homens de origem portuguesa deixaram muitos descendentes com suas escravas. Os 
estudos de Pena e col. (2000) e Carvalho-Silva e col. (2001) realizados com brasileiros de diversas regiões do Brasil indicam alta frequência de cromossomos Y portugueses mesmo nos indivíduos com DNAmt de origem africana. O mesmo também foi observado em outros remanescentes de quilombos e afro-descendentes urbanos (e.g. Bortolini e col, 1999; Ribeiro dos Santos e col, 2002; Hünemeier e col, 2007; Gonçalves e col, 2008).

As comunidades de Pilões e Maria Rosa, assim como Galvão e São Pedro, são muito próximas geograficamente. Pilões e Maria Rosa se formaram em um local distante e de difícil visibilidade. Escravos fugiam para o local, onde se instalaram e desenvolviam atividade agrícola para sobreviver. De acordo com os relatos e documentos disponíveis, acredita-se que houve uma ocupação territorial negra em Maria Rosa e em Pilões, na mesma época em que algumas fazendas da região ainda contavam com o trabalho escravo. Em um documento de 1863, o subdelegado de polícia de Iporanga noticia à presidência da Província a existência de negros em quilombos nas proximidades da região. A partir de 1844, os registros de batismo começam a indicar a presença de negros livres nos arredores da região.

Nos dendrogramas construídos (Figuras 23 e 24), as comunidades de Maria Rosa e Pilões não aparecem tão próximas como o esperado. De forma similar, os estudos com marcadores de cromossomo $\mathrm{Y}$ e inserções de Alu nas mesmas comunidades afrodescendentes do Vale do Ribeira (Cotrim e col, 2004; Macedo-Souza, 2003) essas comunidades, de uma maneira geral, aparecem próximas entre si, mas não necessariamente dividindo um mesmo nó ancestral. Nesse caso, os autores sugeriram que o reduzido tamanho amostral de Maria Rosa e um gargalo populacional registrado nas população de Maria Rosa e Pilões entre os anos de 1998 e 2001 podem explicar esse maior distanciamento genético, maior do que o esperado com base nas características geográficas e genealógicas dessas comunidades. Na comunidade de Pilões há predomínio do haplogrupo africano L2 (Tabela II). O haplótipo predominante dentro desse haplogrupo foi HP56 (ver Tabela III). Em Maria Rosa não foi possível estabelecer a predominância de nenhum haplótipo específico. Dado o número pequeno de indivíduos estudados e redução populacional é possível que diversas linhagens de DNA mitocondrial presentes na constituição original dessas comunidades tenham sofrido extinção. 
As comunidades Abobral Margem Esquerda e Abobral Margem Direita, como era esperado, dividem um mesmo nó (Figuras 23 e 24). Divididas pelo rio Ribeira de Iguape, ambas podem ser consideradas como uma única população do ponto de vista genealógico. Distando apenas oito quilômetros da cidade de Eldorado, Abobral é constituída por cerca de 50 a 60 famílias, totalizando aproximadamente 500 habitantes. Segundo consta no Diário das Professoras de UEAC (Unidades Escolares de Ação Comunitária) e de Escolas Rurais de Emergência, os primeiros moradores foram senhores de escravos. Ainda segundo esses relatos, os descendentes de escravos que se mantiveram na área após a saída dos senhores são retratados como formadores de núcleos familiares numerosos.

O haplótipo HP29 é observado com predominância em Abobral Margem Esquerda e está presente no indivíduo mais antigo da comunidade (AB129). Este haplótipo africano deve ser um importante haplótipo fundador da comunidade.

A comunidade de Pedro Cubas, mesmo sem afinidades genealógicas, geográficas ou históricas detectáveis, apresentou proximidade genética com a comunidade de Abobral nos estudos com cromossomo Y e inserções de Alu (Cotrim e col, 2004; Macedo-Souza, 2003). Em nosso estudo, entretanto, essa aproximação não foi observada. Além disso, tanto em relação ao estudo com cromossomo Y como ao estudo das inserções de $A l u$, ocorreu maior aproximação de Pedro Cubas com as comunidades indígenas que em relação as demais comunidades. Nos estudos com marcadores de cromossomo Y, Pedro Cubas foi a comunidade com maior presença de material genético indígena. Nos estudos com DNA mitocondrial, por sua vez, a presença indígena foi equivalente à africana $(50 \%)$ e, como consequência, a aproximação filogenética com as populações ameríndias não foi tão distinta do padrão das demais populações.

De acordo com relatos sobre a origem de Pedro Cubas, o início da ocupação das terras banhadas pelo Rio Pedro Cubas deve-se a Gregório Marinho, escravo fugido da fazenda Caiacanga, de propriedade de Miguel Antônio Jorge, que era filho de um comprador de escravos, que viveu no século XVIII. Outros fundadores da comunidade foram negros escravos que trabalhavam na mineração do ouro. A entrada de fazendeiros na região, principalmente para o cultivo de arroz, banana e criação de gado trouxe pressão pela saída das famílias quilombolas. Não tendo como resistir, várias famílias deixaram suas terras e foram para outras áreas ou cidades. 
Na comunidade de Pedro Cubas o haplogrupo L1c prevalece (Tabela II) e dentro desse grupo destacam-se os haplótipos HP35 (L1c1) e o haplótipo HP41 (L1c3). O indivíduo PC215 desta comunidade se declarou descendente pelo lado materno, de Gregório Marinho, o escravo que teria dado origem à comunidade. Este indivíduo apresentou o haplótipo HP41, pertencente ao inédito haplogrupo mitocondrial africano detectado no Brasil (L1c3). Este achado é indicativo do carácter fundador do haplótipo HP41 na comunidade de Pedro Cubas, pois provavelmente é o haplótipo da mulher de Gregório Marinho.

A família Marinho aparece nos registros também como uma das fundadoras da comunidade de Ivaporunduva. Alguns mencionam a origem de Ivaporunduva ainda no século XVI. Um deles fala de uma antiga proprietária de terras e de escravos, dona Maria Joana, que teria adoecido e morrido enquanto se tratava no exterior. Sendo viúva e não tendo parentes, as terras ficaram para os escravos. Esse fato teria estimulado também a vinda de escravos fugidos, que resistiram à captura dos capitães do mato por volta de 1690, formando o quilombo de Ivaporunduva.

Segundo o livro de tombo da paróquia de Xiririca, antigo nome da cidade de Eldorado, de 1813, Ivaporunduva é a mais antiga das comunidades do Vale do Ribeira. Surge como povoado no século XVII, mesmo antes de Xiririca, por causa da mineração de ouro. Ivaporunduva, primeira comunidade negra do Vale do Ribeira, supõe-se ter funcionado como ancestral das outras comunidades quilombolas que foram aparecendo na região.

Nos dendrogramas construídos apenas com dados dos remanescentes de quilombos do Vale do Ribeira e a amostra de São Paulo (Figuras 24), Pedro Cubas e Ivaporunduva não aparecem geneticamente próximas como o esperado pela afinidade histórica relatada para ambas comunidades por meio da família Marinho. A presença de linhagens ameríndias em Ivaporunduva é mais frequente (67\%) que na comunidade de Pedro Cubas (50\%), fato que deve ter aproximado mais Ivaporunduva dos ameríndios do que de Pedro Cubas. Além disso, em Ivaporunduva é predominante o haplótipo HP12, ameríndio, outro importante haplótipo fundador e que também deve ter contribuído para o seu distanciamento genético da comunidade de Pedro Cubas.

As comunidades de São Pedro, Galvão, Sapatu e Ivaporunduva aparecem próximas um das outras nos dendrograma construídos (Figuras 23 e 24). De acordo com relatos, os primeiros moradores de Sapatu vieram de São Pedro e de Ivaporunduva. Descendentes de 
Bernardo Furquim, fundador do bairro de São Pedro, mudaram-se para Sapatu. Este dado histórico pode explicar a aproximação filogenética observada entre estas quatro comunidades. Dados haplotípicos também reforçam essa aproximação. O haplótipo HP12, ameríndio, é frequente em todas as quatro comunidades (ver Tabela III). Outro haplótipo frequente nas quatro comunidades foi HP09. Este haplótipo foi detectado também em praticamente todas as comunidades afro-descendentes do Vale do Ribeira e foi especialmente predominante na comunidade de Sapatu.

As comunidades de Nhunguara e André Lopes aparecem próximas nos dendrogramas construídos (Figuras 23 e 24). Essa aproximação genética é apoiada pela geografia e pelos relatos históricos. Estes dois bairros vizinhos, além de possuírem estreitas relações de parentesco, têm origem histórica comum. Os primeiros moradores do bairro são os Vieira, Dias e Maia, que, por sua vez, casaram-se com mulheres de Ivaporunduva.

A comunidade da Poça permaneceu próxima à cidade de São Paulo nos dendrogramas construídos (Figuras 23 e 24). Esta comunidade forma um clado com a cidade de São Paulo, separado das demais comunidades afro-descendentes. Pouco se sabe até o momento sobre a história da comunidade da Poça. Relatos de moradores indicam que há indivíduos descendentes da família Marinho, de Ivaporunduva. Também há referência de ancestrais de provenientes da comunidade de Nhunguara. Nos estudos com DNA mitocondrial, a comunidade da Poça apresentou, entre todas as comunidades afro-descendentes do Vale do Ribeira, as frequências mais elevadas de linhagens européias (10\%), fato que provocou sua agregação com São Paulo e seu distanciamento das demais comunidades quilombolas.

As amostras de populações portuguesas e de brasileiros brancos formaram um clado separado, distante de todos os demais grupos populacionais (Figura 24), como esperado. Esse distanciamento certamente se deve a sua alta frequência de linhagens européias, ausentes ou em baixas frequências nos demais grupos populacionais incluídos.

Como última análise, reunimos todas as comunidades afro-descendentes do Vale do Ribeira, considerando-as como um único grupo populacional, e construímos um dendrograma para avaliar suas relações filogenéticas com os demais grupos de referência selecionados da literatura (Figura 25). A cidade de São Paulo formou um clado com os afro-descendentes do Vale do Ribeira. Em nosso estudo, foi elevado o compartilhamento de linhagens mitocondriais, tanto africanas como ameríndias, entre São Paulo e as 
comunidades do Vale do Ribeira (ver Tabela IV), o que explica essa aproximação filogenética. Já os afro-brasileiros formaram um segundo clado com os Banto africanos e ambas amostragens compartilham um ancestral comum com o clado formado pelas amostras de São Paulo e do Vale do Ribeira. Como esperado, e concordante com todas as observações sobre sequências que já apresentamos, a presença significativa de sequências africanas de origem Banto é uma marca importante das quatro amostragens avaliadas, o que explica sua aproximação na filogenia.

No grupo dos afro-brasileiros e nas comunidades do Vale do Ribeira, especialmente entre os das comunidades rurais, a presença de linhagens ameríndias também é elevada. As amostras ameríndias neste trabalho são representadas por material genético dos Guarani e Kaigang do centro-sul do Brasil. Diversos haplótipos presentes nesse material indígena são compartilhados com os demais grupos predominantemente africanos. Este fato, pode explicar a curiosa aproximação observada entre ameríndios e as populações de ascendência africana nessa árvore.

Finalmente, como um clado separado, aproximaram-se as amostras de Brasileiros Brancos, de ancestralidade predominantemente européia, e as populações de origem portuguesa, como é esperado. A fração européia que aportou em terras brasileiras durante o processo de colonização e que se manteve em destaque durante todo o período corresponde à dos portugueses. As linhagens européias que predominam na população brasileira, são as mesmas linhagens que predominam na península ibérica, especialmente na região do território de Portugal (Alves-Silva e col, 2000; Marrero e col, 2005). 


\section{6 - CONCLUSÕES}




\section{6 - Conclusões}

Visto que a história da ocupação do Vale do Ribeira foi o produto de interações étnicosociais, principalmente com sociedades indígenas que já estavam estabelecidas na área, nossos resultados são surpreendentes, porém explicáveis. Nas doze populações de quilombo, importante contribuição ameríndia (com 49,3\% de linhagens) e africana (49,2\% das linhagens) foram detectadas e poucas linhagens européias foram observadas. Os resultados de sequenciamento da região hipervariável I sugerem uma origem étnica predominantemente a partir dos Bantos para a fração do DNA mitocondrial africano no Vale do Ribeira. A significativa assimilação de linhagens ameríndias observada nos indivíduos remanescentes de quilombos é um indicativo de que as interações entre quilombolas e sociedades indígenas ocorreram por meio de mulheres indígenas. Em especial, o sequenciamento da região hipervariável I indica provável contribuição Kaigang e Guarani na fração do DNA mitocondrial ameríndia.

É importante mencionar que nos estudos de Macedo-Souza (2003) e Kimura (2004) conduzidos no nosso laboratório, raríssimas linhagens de cromossomo Y ameríndias foram detectadas nessas populações. Chamou a atenção nesses estudos a elevada fração de haplogrupos de Y considerados europeus. A contribuição européia, por outro lado, foi pouco expressiva nos nossos estudos de DNA mitocondrial. Portanto, a presença indígena nos quilombos ocorreu por meio de mulheres e não por homens.

Em relação aos haplótipos, foi possível identificar em quase todas as comunidades afrodescendentes do Vale do Ribeira haplótipos predominantes, candidatos a fundadores, exceção feita a Maria Rosa, André Lopes, Nhunguara e Poça. O haplótipo HP12 (Haplogrupo B), haplótipo provável de uma das esposas de Bernardo Furquim, foi predominante em Galvão, São Pedro e Ivaporunduva; o haplótipo HP56 (Haplogrupo L2d) foi o principal em Pilões; o haplótipo HP29 (Haplogrupo L1c1) se destaca em Abobral; o haplótipo HP41 (Haplogrupo L1c3), possivelmente herdado da mulher de Gregório Marinho, se destaca em Pedro Cubas; em Sapatu é frequente o haplótipo HP09 (Haplogrupo B). Galvão foi a comunidade de quilombo que evidenciou maior efeito de

fundador e, consequentemente, onde se observou o menor índice de diversidade haplotípica. 
$\mathrm{Na}$ análise dos dendrogramas, as comunidades quilombolas de Galvão, São Pedro, Sapatu e Ivaporunduva mostram-se mais próximas das populações ameríndias. As demais comunidades quilombolas (André Lópes, Poça, Pedro Cubas, Abobral, Nhunguara, Pilões e Maria Rosa) estão geneticamente mais próximas de populações da etnia Banto. A comunidade da Poça se manteve próxima a São Paulo e separada das demais comunidades quilombolas, provavelmente devido à maior presença de material genético europeu. As proximidades genéticas observadas entre Galvão e São Pedro; Abobral Margem Esquerda e Margem Direita; São Pedro, Galvão, Sapatu e Ivaporunduva e, finalmente, entre Nhunguara e André Lopes, têm concordância com os registros históricos que atestam para proximidade genealógica e geográfica desses grupos. Pilões e Maria Rosa não se apresentaram tão próximas entre si, como esperado, provavelmente devido à redução do tamanho populacional. Os demais afro-descendentes do Brasil e populações da etnia banto, como esperado, formaram um clado, assim como as populações de origem portuguesa e os brasileiros brancos.

Os nossos resultados e os da literatura apontam para uma formação genética e histórica muito rica e diversa nos remanescentes de quilombos. O que os estudos genéticos revelaram de mais notável foi a contribuição genética indígena preservada nos quilombos, que começa a ser resgatada, após anos e anos de depopulação provocada pela entrada de grupos europeus, no continente americano. Esperamos que nosso estudo, além de contribuir para retratar a diversidade genética dos povos afro-brasileiros, possa contribuir com o resgate da história de povos ameríndios no sudeste, deslocados pela ocupação européia. 


\section{7 - REFERÊNCIAS BIBLIOGRÁFICAS}




\section{7 - Referências}

ABE-SANDES, K. Diversidade genética de afro-brasileiros: DNA mitocondrial e cromossomo Y. (2002). PhD - Tese de Doutorado, FMRPUSP, Universidade de São Paulo, Ribeirão Preto, Brasil, 2002.

ABREU-SILVA, R. S. Susceptibilidade genética à perda auditiva induzida por ruído (PAIR). (2008). PhD - Tese de Doutorado, IBUSP, Universidade de São Paulo, São Paulo, Brasil, 2008.

ACHILLI, A. et al. The phylogeny of the four pan-American MtDNA haplogroups: implications for evolutionary and disease studies. PLOS ONE [S.I.], v. 3, n. 3, p. e1764, 2008.

ALLARD, M. W. et al. Characterization of the Caucasian haplogroups present in the SWGDAM forensic mtDNA dataset for 1771 human control region sequences. Scientific Working Group on DNA Analysis Methods. J Forensic Sci [S.I.], v. 47, n. 6, p. 1215-23, Nov 2002.

Control region sequences for East Asian individuals in the Scientific Working Group on DNA Analysis Methods forensic mtDNA data set. Leg Med (Tokyo) [S.I.], v. 6, n. 1, p. 11-24, Mar 2004.

ALMEIDA, A. P. Memória Histórica de Xiririca (Eldorado Paulista). São Paulo, Brasil: Departamento do Arquivo do Estado de São Paulo, Secretaria da Educação, 1955.

ALPERS, E. A. Moçambiques in Brazil: another dimension of the African diaspora in the Atlantic World; in: Curto JC, Soulandre-LaFrance (eds) Africa and the Americas: Interconections during the slave trade. Lawrenceville - NJ: Africa World Press, 1997.

ALVES-SILVA, J. et al. The ancestry of Brazilian mtDNA lineages. Am J Hum Genet [S.I.], v. 67, N. 2, p. 444-61, Aug 2000.

ANDERSON, S. et al. Sequence and organization of the human mitochondrial genome. Nature [S.I.], v. 290, n. 5806, p. 457-65, Apr 91981.

ANDRADE, T. et al. Negros do Ribeira: Reconhecimento Étnica e Conquista do Território. São Paulo, Brasil: ITESP, 2000.

ANJOS, R. S. A. Territórios das comunidades remanescentes de antigos quilombos no Brasil - Primeira configuração espacial. Brasília - DF: Mapas Editora e Consultoria, 2000.

ARCTANDER, P. Mitochondrial recombination? Science [S.I.], v. 284, p. 2090-2091, 1999. 
ATKINSON, Q. D. et al. mtDNA variation predicts population size in humans and reveals a major Southern Asian chapter in human prehistory. Mol Biol Evol [S.I.], v. 25, n. 2, p. 468-74, Feb 2008.

AURICCHIO, M. T. B. M. et al. Frequency and origins of HBB*S mutation in Africanderived Brazilian populations. Human Biology [S.I.], v. 79, n. 9, p. 667-678, 2007.

AWADALLA, P. et al. Linkage disequilibrium and recombination in hominid mitochondrial DNA. Science [S.I.], v. 286, p. 2524-2525, 1999.

AZEVEDO, R.; CASTRO, E. Negros do Trombetas. Guardiães de mata e rios. . Belém PA: Cejup, 1998.

BAILLIET, G. et al. Founder mitochondrial haplotypes in Amerindian populations. Am J Hum Genet [S.I.], v. 55, n. 1, p. 27-33, Jul 1994.

BALLARD, J. W. O.; RAND, D. M. The population biology of mitochondrial DNA and its phylogenetic implications. Annual Review of Ecology, Evolution, and Systematics [S.I.], v. 36, p. 621-642, 2005.

BANDELT, H. J. et al. Median-joining networks for inferring intraspecific phylogenies. Mol Biol Evol [S.I.], v. 16, n. 1, p. 37-48, Jan 1999.

Mitochondrial portraits of human populations using median networks. Genetics [S.I.], v. 141, n. 2, p. 743-53, Oct 1995.

Identification of Native American founder mtDNAs through the analysis of complete mtDNA sequences: some caveats. Ann Hum Genet [S.I.], v. 67, n. Pt 6, p. 512-24, Nov 2003.

. Detecting errors in mtDNA data by phylogenetic analysis. Int J Legal Med [S.I.], v. 115, n. 2, p. 64-9, Oct 2001.

Median networks: speedy construction and greedy reduction, one simulation, and two case studies from human mtDNA. Mol Phylogenet Evol [S.I.], v. 16, n n. 1, p. 8-28, Jul 2000.

BARBOSA, A. B. G. et al. Mitochondrial DNA control region polymorphism in the population of Alagoas State, North-Eastern Brazil. Journal of Forensic Science [S.I.], v. 53, n. 1, p. 142-146, 2008.

BATINI, C. et al. Phylogeography of the human mitochondrial L1c haplogroup: genetic signatures of the prehistory of Central Africa. Mol Phylogenet Evol [S.I.], v. 43, n. 2, p. 635-44, May 2007.

BATTILANA, J. et al. Alu insertions versus blood group plus protein genetic variability in four Amerindian populations. Ann Hum Biol [S.I.], v. 29, n. 3, p. 334-47, May-Jun 2002. 
BEHAR, D. M. et al. The Genographic Project public participation mitochondrial DNA database. PLoS Genet [S.I.], v. 3, n. 6, p. e104, Jun 2007.

BEIGUELMAN, B. Dinâmica dos genes nas famílias e nas populações Ribeirão Preto, São Paulo, Brasil, 1994.

BELEZA, S. et al. The genetic legacy of western Bantu migrations. Hum Genet [S.I.], v. 117, N. 4, p. 366-75, Aug 2005.

BETHELL, L. Nota sobre as populações americanas às vesperas das invasões européias. In: Bethell L (ed) América Latina colonial. São Paulo - SP: Editora Universidade de São Paulo, 1997.

BEZERRA-NETO, J. M. Escravidão negra na Amazônia (Sécs. XVII - XIX). Belém - PA: Paka-Tatu, 2001.

BIANCHI, N. O. et al. Peopling of the Americas as inferred through the analisys of mitochondrial DNA. Brazilian Journal of Genetics [S.I.], v. 18, p. 661-668, 1995.

BONATTO, S. L.; SALZANO, F. M. Diversity and age of the four major mtDNA haplogroups, and their implications for the peopling of the New World. Am J Hum Genet [S.I.], v. 61, n. 6, p. 1413-23, Dec 1997a.

A single and early migration for the peopling of the Americas supported by mitochondrial DNA sequence data. Proc Natl Acad Sci U S A [S.I.], v. 94, n. 5, p. 1866-71, Mar 4, $1997 b$.

BORTOLINI, M. C. et al. Evolutionary relationships between black South American and African populations. Hum Biol [S.I.], v. 67, n. 4, p. 547-59, Aug 1995.

Evolutionary and anthropological implications of mitochondrial DNA variation in African Brazilian populations. Hum Biol [S.I.], v. 69, n. 2, p. 141-59, Apr 1997.

Diversity in protein, nuclear DNA, and mtDNA in South Amerinds--agreement or discrepancy? Ann Hum Genet [S.I.], v. 62, n. Pt 2, p. 133-45, Mar 1998.

African-derived South American populations: A history of symmetrical and asymmetrical matings according to sex revealed by bi- and uni-parental genetic markers. Am J Hum Biol [S.I.], v. 11, n. 4, p. 551-563, 1999.

Y-chromosome biallelic polymorphisms and Native American population structure. Ann Hum Genet [S.I.], v. 66, n. Pt 4, p. 255-9, Jul 2002.

Y-chromosome evidence for differing ancient demographic histories in the Americas. Am J Hum Genet [S.I.], v. 73, n. 3, p. 524-39, Sep 2003.

BORTOLINI, M. C.; PENA, S. D. Pode a genética definir quem pode se beneficiar das cotas universitárias e demais ações. Estudos Avançados [S.I.], v. 18, n. 50, p. 31-51, 2004. 
BRANDÃO-FERREIRA, L. Diversidade do DNA mitochondrial de populações brasileiras ameríndias e afrodescendentes. (2006). PhD - Tese de Doutorado, FMRPUSP, Universidade de São Paulo, Ribeirão Preto, Brasil, 2006.

BRAVI, C. M. et al. Characterization of mitochondrial DNA and Y-chromosome haplotypes in a Uruguayan population of African ancestry. Hum Biol [S.I.], v. 69, n. 5, p. 641-52, Oct 1997.

BROMHAM, L. et al. Mitochondrial Steve: paternal inheritance of mitochondria in humans. TRENDS in Ecology and Evolution [S.I.], v. 18, N. 1, p. 2-4, 2003.

BROWN, M. D. et al. mtDNA haplogroup X: An ancient link between Europe/Western Asia and North America? Am J Hum Genet [S.I.], v. 63, n. 6, p. 1852-61, Dec 1998.

BUDOWLE, B. et al. Forensics and mitochondrial DNA: applications, debates, and foundations. Annu Rev Genomics Hum Genet [S.I.], v. 4, p. 119-41, 2003.

CALLEGARI-JACQUES, S. M.; SALZANO, F. M. Brazilian Indian/non-Indian interactions and their effects. Ciência e Cultura: Journal of the Brazilian Association for the Advancement of Science [S.I.], v. 51, p. 166-174, 1999.

CALLEGARI-JACQUES, S. M. et al. The Wai Wai Indians of South America: history and genetics. Ann Hum Biol [S.I.], v. 23, n. 3, p. 189-201, May-Jun 1996.

Further blood genetic studies on Amazonian diversity--data from four Indian groups. Ann Hum Biol [S.I.], v. 21, n. 5, p. 465-81, Sep-Oct 1994.

CANN, R. L. mtDNA and Native Americans: a Southern perspective. Am J Hum Genet [S.I.], v. 55, n. 1, p. 7-11, Jul 1994.

CANN, R. L. et al. Mitochondrial DNA and human evolutioN. Nature [S.I.], v. 325, N. 6099, p. 31-6, Jan 1-7 1987.

CARDOSO, G. L.; GUERREIRO, J. F. frican gene flow to north Brazil as revealed by HBB*S gene haplotype analysis. American Journal of Human Biology [S.I.], v. 18, p. 9398, 2006.

CARENO, M. F. Vale do Ribeira: a voz e a vez das comunidades negras. São Paulo, Brasil: UNIP, 1997.

CARNEIRO DA CUNHA, M. História dos Índios no Brasil. São Paulo, Brasil: Companhia das Letras, 1992.

CARRIL, L. F. B. Terra de Negros no Vale do Ribeira : Territorialidade e Resistência. (1995). Msc - Dissertação de Mestrado, FFLCH/USP, Universidade de São Paulo, São Paulo, Brasil, 1995. 
CARVALHO, B. M. et al. Mitochondrial DNA mapping of social-interactions in Brazilian Amazonian African-descendent populations. Genetics and Molecular Biology [S.I.], v. 31, n. 1, p. 12-22, 2008.

CARVALHO-SILVA, D. R. et al. The phylogeography of Brazilian Y-chromosome lineages. Am J Hum Genet [S.I.], v. 68, N. 1, p. 281-6, Jan 2001.

CAVALLI-SFORZA, L. L. The DNA revolution in population genetics. Trends Genet [S.I.], v. 14, N. 2, p. 60-5, Feb 1998.

The Human Genome Diversity Project: past, present and future. Nat Rev Genet [S.I.], v. 6, N. 4, p. 333-40, Apr 2005.

CAVALLI-SFORZA, L. L.; FELDMAN, M. W. The application of molecular genetic approaches to the study of human evolutioN. Nat Genet [S.I.], v. 33 Suppl, p. 266-75, Mar 2003.

CAVALLI-SFORZA, L. L. et al. The history and geography of human genes. USA: Princeton University Press, 1996.

CHEN, F. et al. Genetic polymorphism of mitochondrial DNA HVS-I and HVS-II of Chinese Tu ethnic minority group. Journal of Genetics and Genomics [S.I.], v. 35, p. 225$232,2008$.

CHEN, Y. S. et al. mtDNA variation in the South African Kung and Khwe-and their genetic relationships to other African populations. Am J Hum Genet [S.I.], v. 66, n. 4, p. 1362-83, Apr 2000.

COBLE, M. D. et al. Effective strategies for forensic analysis in the mitochondrial DNA coding region. Int J Legal Med [S.I.], v. 120, n. 1, p. 27-32, Jan 2006.

CONDIT, C. M. et al. The changing meanings of "mutation:" A contextualized study of public discourse. Hum Mutat [S.I.], v. 19, n. 1, p. 69-75, Jan 2002.

CONSORTIUM, I. H. A second generation of human haplotype map over 3,1 million SNPs. Nature [S.I.], v. 449, p. 851-861, 2007.

CONSORTIUM, I. H. G. S. Initial sequencing and analysis of the humans genome. Nature [S.I.], v. 409, p. 860-921, 2001.

COTRIM, N. H. et al. Polymorphic Alu insertions in six Brazilian African-derived populations. Am J Hum Biol [S.I.], v. 16, n. 3, p. 264-77, May-Jun 2004.

CRESPILLO, M. et al. Mitochondrial DNA sequences for 118 individuals from northeastern SpaiN. Int J Legal Med [S.I.], v. 114, n. 1-2, p. 130-2, 2000. 
CUMMINGS, M. R. A healthy hiring approach. J Healthc Prot Manage [S.I.], v. 17, n. 1, p. 70-9, Winter 2000.

CURTIN, P. D. The Atlantic slave trade: a census. Madison - USA: University of Wisconsin Press, 1969.

DEL PRIORE, M.; VENÂNCIO, R. P. O Livro de Ouro da História do Brasil.: Ediouro Publicações S.A., 2001.

DENARO, M. et al. Ethnic variation in Hpa 1 endonuclease cleavage patterns of human mitochondrial DNA. Proceedings of the National Academy of Sciences [S.I.], v. 78, n. 9, p. 5768-5772, 1981.

DERBENEVA, O. A. et al. Traces of early Eurasians in the Mansi of northwest Siberia revealed by mitochondrial DNA analysis. Am J Hum Genet [S.I.], v. 70, n. 4, p. 1009-14, Apr 2002.

DERENKO, M. et al. Phylogeographic analysis of mitochondrial DNA in northern Asian populations. Am J Hum Genet [S.I.], v. 81, n. 5, p. 1025-41, Nov 2007.

DORNELLES, C. L. et al. Is haplogroup X present in extant South American Indians? Am J Phys Anthropol [S.I.], v. 127, n. 4, p. 439-48, Aug 2005.

Genetics, surnames, grandparents nationalities, and ethnic admixture in Southern Brazil: do the parents of variation coincide? Genetics and Molecular Biology [S.I.], v. 22, p. 151-161, 1999.

DRUZHYNA, N. M. et al. Mitochondrial DNA repair in aging and disease. Mech Ageing Dev [S.I.], v. 129, n. 7-8, p. 383-90, Jul-Aug 2008.

ELSON, J. L. et al. Analysis of European mtDNAs for RecombinatioN. American Journal of Human Genetics [S.I.], v. 68, n. 1, p. 145-153, 2001.

EYRE-WALKER, A. et al. How clonal are human mitochondria? Proceedings of the Royal Society B: Biological Sciences [S.I.], v. 266, p. 477-483, 1999.

FADHLAOUI-ZID, K. et al. Mitochondrial DNA heterogeneity in Tunisian Berbers. Ann Hum Genet [S.I.], v. 68, n. Pt 3, p. 222-33, May 2004.

FAGUNDES, N. J. et al. Genetic, geographic, and linguistic variation among South American Indians: possible sex influence. Am J Phys Anthropol [S.I.], v. 117, n. 1, p. 6878, Jan 2002.

FAGUNDES, N. J. R. et al. A Reevaluation of the Native American MtDNA Genome Diversity and Its Bearing on the Models of early Colonization of Beringia. PLOS One [S.I.], v. 3, n. 3, p. e3157, 2008 b. 
Mitochondrial Population Genomics Supports a Single Pre-Clovis Origin with a Coastal Route for the Peopling of the Americas. The American Journal of Human Genetics [S.I.], v. 82, p. 583-592, 2008a.

FEIO-DOS-SANTOS, A. C. et al. Nucleotide variability of HV-I in admixed population of the Brazilian Amazon RegioN. Forensic Sci Int [S.I.], v. 164, n. 2-3, p. 276-7, Dec 20 2006.

FIEDEL, S. J. The peopling of the new world: present evidence, new theories, and future directions. Journal of Archaeological Research [S.I.], v. 8, p. 39-103, 2000.

FIGUEIREDO, M. S. et al. The heterogeneity of the beta s cluster haplotypes in Brazil. Gene Geogr [S.I.], v. 8, n. 1, p. 7-12, Apr 1994.

FILOSTO, M. et al. Lack of paternal inheritance of muscle mitochondrial DNA in sporadic mitochondrial myopathies. Ann Neurol [S.I.], v. 54, n. 4, p. 524-6, Oct 2003.

FIX, A. G. Colonization models and initial genetic diversity in the Americas. Hum Biol [S.I.], v. 74, N. 1, p. 1-10, Feb 2002.

FLORENTINO, M. Em costas negras. São Paulo, Brasil: Companhia das Letras, 1997.

FORSTER, P. Ice Ages and the mitochondrial DNA chronology of human dispersals: a review. Philos Trans $R$ Soc Lond B Biol Sci [S.I.], v. 359, n. 1442, p. 255-64; discussion 264, Feb 292004.

FORSTER, P. et al. Origin and evolution of Native American mtDNA variation: a reappraisal. Am J Hum Genet [S.I.], v. 59, n. 4, p. 935-45, Oct 1996.

FORSTER, P.; MATSUMURA, S. Evolution. Did early humans go north or south? Science [S.I.], v. 308, n. 5724, p. 965-6, May 132005.

FRAZER, K. A. et al. A second generation human haplotype map of over 3.1 million SNPs. Nature [S.I.], v. 449, n. 7164, p. 851-61, Oct 182007.

GONCALVES, M. S. et al. BetaS-haplotypes in sickle cell anemia patients from Salvador, Bahia, Northeastern Brazil. Braz J Med Biol Res [S.I.], v. 36, n. 10, p. 1283-8, Oct 2003.

Sickle cell disease in a Brazilian population from Sao Paulo: a study of the beta $\mathrm{s}$ haplotypes. Hum Hered [S.I.], v. 44, n. 6, p. 322-7, Nov-Dec 1994.

GONCALVES, V. F. et al. The phylogeography of African Brazilians. Hum Hered [S.I.], v. 65 , n. 1, p. 23-32, 2008.

GONDER, M. K. et al. Whole-mtDNA genome sequence analysis of ancient African lineages. Mol Biol Evol [S.I.], v. 24, n. 3, p. 757-68, Mar 2007. 
GRAVEN, L. et al. Evolutionary correlation between control region sequence and restriction polymorphisms in the mitochondrial genome of a large Senegalese Mandenka sample. Mol Biol Evol [S.I.], v. 12, n. 2, p. 334-45, Mar 1995.

GREEN, L. D. et al. mtDNA affinities of the peoples of North-Central Mexico. Am J Hum Genet [S.I.], v. 66, n. 3, p. 989-98, Mar 2000.

GUERREIRO, J. F. et al. Genetical-demographic data from two Amazonian populations composed of descendants of African slaves: Pacoval and Curiaú. Genetics and Molecular Biology [S.I.], v. 22, p. 163-167, 1999.

HAGELBERG, E. et al. Evidence for mitochondrial DNA recombination in a human population of island Melanesia. Proceedings of the Royal Society B: Biological Sciences [S.I.], v. 266, p. 485-492, 1999.

HALL, T. A. BioEdit: a user-friendly biological sequence alignment editor and analysis program for Windows 95/98/NT. Nucleid Acid Symposium Series [S.I.], v. 41, p. 95-98, 1999.

HEDGES, S. B. et al. Human origins and analysis of mitochondrial DNA sequences. Science [S.I.], v. 255, n. 5045, p. 737-9, Feb 71992.

HEDMAN, M. et al. Finnish mitochondrial DNA HVS-I and HVS-II population data. Forensic Sci Int [S.I.], v. 172, n. 2-3, p. 171-8, Oct 252007.

HELGASON, A. et al. mtDna and the islands of the North Atlantic: estimating the proportions of Norse and Gaelic ancestry. Am J Hum Genet [S.I.], v. 68, n. 3, p. 723-37, Mar 2001.

HERTZBERG, M. et al. An Asian-specific 9-bp deletion of mitochondrial DNA is frequently found in Polynesians. Am J Hum Genet [S.I.], v. 44, n. 4, p. 504-10, Apr 1989.

HORAI, S. et al. Peopling of the Americas, founded by four major lineages of mitochondrial DNA. Mol Biol Evol [S.I.], v. 10, n. 1, p. 23-47, Jan 1993.

HUNEMEIER, T. et al. Niger-Congo speaking populations and the formation of the Brazilian gene pool: mtDNA and Y-chromosome data. Am J Phys Anthropol [S.I.], v. 133, n. 2, p. 854-67, Jun 2007.

INGMAN, M.; GYLLENSTEN, U. Analysis of the complete human mtDNA genome: methodology and inferences for human evolutioN. J Hered [S.I.], v. 92, n. 6, p. 454-61, Nov-Dec 2001.

INGMAN, M. et al. Mitochondrial genome variation and the origin of modern humans. Nature [S.I.], v. 408, n. 6813, p. 708-13, Dec 72000. 
ISENBERG, A. R.; MOORE, J. M. Mitochondrial DNA Analysis at the FBI Laboratory. Forensic Science Communications [S.I.], v. 1, n. 2, p. 1-10, 1999.

JIN, H. J. et al. Forensic genetic analysis of mitochondrial DNA hypervariable region I/II sequences: an expanded Korean population database. Forensic Sci Int [S.I.], v. 158, n. 2-3, p. 125-30, May 102006.

JOBLING, M. A. et al. Human Evolutionary Genetics: Origins, Peoples and Disease. New York, USA: Garland Science, 2004.

JOHNSON, M. J. et al. Radiation of human mitochondria DNA types analyzed by restriction endonuclease cleavage patterns. J Mol Evol [S.I.], v. 19, n. 3-4, p. 255-71, 1983.

JORDE, L. B.; BAMSHAD, M. Questioning evidence for recombination in human mitochondrial DNA. Science [S.I.], v. 288, p. 1931a, 2000.

KIMURA, L. Estudo da mistura gênica nos remanescentes de quilombos do Vale do Ribeira: a origem dos cromossomos Y. . (2004). Dissertação de Iniciação Científica, IBUSP, Universidade de São Paulo, São Paulo, Brasil, 2004.

KITCHEN, A. et al. A three-stage colonization model for the peopling of the Americas. PLoS ONE [S.I.], v. 3, n. 2, p. e1596, 2008.

KIVISILD, T. et al. Ethiopian mitochondrial DNA heritage: tracking gene flow across and around the gate of tears. Am J Hum Genet [S.I.], v. 75, n. 5, p. 752-70, Nov 2004.

KIVISILD, T.; VILLEMS, R. Questioning Evidence for Recombination in Human Mitochondrial DNA. Science [S.I.], v. 288, p. 1931a, 2000.

KLEIN, H. S. As origens Africanas dos escravos brasileiros; in Pena SDL (ed): Homo brasilis: aspectos genéticos, linguísticos, históricos e socioantropológicos da formação do povo brasileiro. Ribeirão Preto, Brasil: FUNPEC, 2002.

KOLMAN, C. J. et al. Mitochondrial DNA analysis of Mongolian populations and implications for the origin of New World founders. Genetics [S.I.], v. 142, n. 4, p. 1321-34, Apr 1996.

KRAYTSBERG, Y. et al. Recombination of human mitochondrial DNA. Science [S.I.], v. 304, p. 981, 2004.

KRINGS, M. et al. mtDNA analysis of Nile River Valley populations: A genetic corridor or a barrier to migration? Am J Hum Genet [S.I.], v. 64, n. 4, p. 1166-76, Apr 1999.

KUMAR, S. et al. MEGA3: Integrated software for molecular evolutionary genetics analysis and sequence alignment. Briefings in Bioinformatics [S.I.], v. 5, p. 510-163, 2004. 
KVIST, L. et al. Paternal leakage of mitochondrial DNA in the great tit (Parus major). Molecular Biology and Evolution [S.I.], v. 20, p. 243-247, 2003.

LEE, H. Y. et al. Mitochondrial DNA control region sequences in Koreans: identification of useful variable sites and phylogenetic analysis for mtDNA data quality control. Int $J$ Legal Med [S.I.], v. 120, n. 1, p. 5-14, Jan 2006.

LIND, J. M. et al. Elevated male European and female African contributions to the genomes of African American individuals. Hum Genet [S.I.], v. 120, n. 5, p. 713-22, Jan 2007.

LUTZ, S. et al. A third hypervariable region in the human mitochondrial D-loop. Hum Genet [S.I.], v. 101, n. 3, p. 384, Dec 1997.

MABUCHI, T. et al. Typing the $1.1 \mathrm{~kb}$ control region of human mitochondrial DNA in Japanese individuals. J Forensic Sci [S.I.], v. 52, n. 2, p. 355-63, Mar 2007.

MACA-MEYER, N. et al. Major genomic mitochondrial lineages delineate early human expansions. BMC Genet [S.I.], v. 2, p. 13, 2001.

MACAULAY, V. et al. Mitochondrial DNA recombination-no need to panic. Proceedings of the Royal Society B: Biological Sciences [S.I.], v. 266, p. 2037-2039, 1999.

MACEDO-SOUZA, L. L. Variabilidade molecular do cromossomo Y em remanescentes de quilombos do Vale do Ribeira. (2003). Msc - Dissertação de Mestrado, IBUSP, Universidade de São Paulo, São Paulo, Brasil, 2003.

MANFREDI, G. et al. The fate of human sperm-derived mtDNA in somatic cells. Am J Hum Genet [S.I.], v. 61, n. 4, p. 953-60, Oct 1997.

MARINHO, A. N. R. Mutações na região controle do DNA mitocondrial em uma amostra de indivíduos jovens e idosos da população de Belém. (2004). Msc - Dissertação de Mestrado, Universidade Federal do Pará, Belém, Brasil, 2004.

MARRERO, A. R. et al. Heterogeneity of the genome ancestry of individuals classified as White in the state of Rio Grande do Sul, Brazil. Am J Hum Biol [S.I.], v. 17, n. 4, p. 496506, Jul-Aug 2005.

. Demographic and evolutionary trajectories of the Guarani and Kaingang natives of Brazil. Am J Phys Anthropol [S.I.], v. 132, n. 2, p. 301-10, Feb 2007.

MARUYAMA, S. et al. Sequence polymorphisms of the mitochondrial DNA control region and phylogenetic analysis of mtDNA lineages in the Japanese population. Int $J$ Legal Med [S.I.], v. 117, n. 4, p. 218-25, Aug 2003. 
MATEU, E. et al. A tale of two islands: population history and mitochondrial DNA sequence variation of Bioko and Sao Tome, Gulf of Guinea. Ann Hum Genet [S.I.], v. 61, n. Pt 6, p. 507-18, Nov 1997.

MELLARS, P. Why did modern human populations disperse from Africa ca. 60,000 years ago? A new model. Proc Natl Acad Sci U S A [S.I.], v. 103, n. 25, p. 9381-6, Jun 202006.

MENDES-JÚNIOR, C. T. DNA mitocondrial na Amazônia brasileira: estrutura genética e inferências continentais. (2005). PhD - Dissertação de Doutorado, FMRPUSP, Universidade de São Paulo, Ribeirão Preto, Brasil, 2005.

MENDIZABAL, I. et al. Genetic origin, admixture, and asymmetry in maternal and paternal human lineages in Cuba. BMC Evolutionary Biology [S.I.], v. 8, p. 213, 2008.

MERRIWETHER, D. A. et al. The structure of human mitochondrial DNA variation. J Mol Evol [S.I.], v. 33, n. 6, p. 543-55, Dec 1991.

MERRIWETHER, D. A.; KAESTLE, F. A. Mitochondrial recombination? (continued). Science [S.I.], v. 285, p. 837, 1999.

MISHMAR, D. et al. Natural selection shaped regional mtDNA variation in humans. Proc Natl Acad Sci U S A [S.I.], v. 100, n. 1, p. 171-6, Jan 72003.

MONTEIRO, J. M. Negros da terra: índios e bandeirantes nas origens de São Paulo. São Paulo, Brasil: Companhia da Letras, 1994.

MOROVVATI, S. et al. Sequence analysis of mitochondrial DNA hypervariable regions: an approach to personal identification. Arch Med Res [S.I.], v. 38, n. 3, p. 345-9, Apr 2007.

NEI, M. Stochastic errors in DNA evolution and molecular phylogeny. In Evolutionary perspective and the new genetics (H. Gershowitz, ed.). New York, USA: Alan R. Liss, 1986.

1987.

Molecular evolutionary genetics. New York, USA: Columbia University Press,

NEI, M.; JIN, L. Variances of the average numbers of nucleotide sobstitutions within and between populations. Molecular Biology and Evolution [S.I.], v. 6, p. 290-300, 1989.

NEI, M.; KUMAR, S. Molecular Evolution and Phylogenetics. New York, USA: Oxford University Press, 2000.

OLIVEIRA JR, N. A. et al. Comunidades Negras de Ivaporunduva, São Pedro, Pedro Cubas, Sapatu, Nhunguara, André Lópes, Maria Rosa e Pilões in Andrade T, Pereira CAC, Andrade MRO (eds.) - Negros do Ribeira: reconhecimento étnico e conquista do território. ITESP: Páginas e Letras. São Paulo, SP, Brasil: Editora Gráfica, 2000. 
PAES, G. S. M. Considerações sobre o Passado e o Presente in Volochko A, Batista E (Eds.) - Saúde nos Quilombos. ITESP. São Paulo, Brasil: Instituto de Saúde - SESSP, 2009.

PAJNIČ, Z. et al. Sequence polymorphism of the mitochondrial DNA control region in the Slovenian population. International Journal of Legal Medicine [S.I.], v. 118, p. 1-4, 2004.

PAKENDORF, B.; STONEKING, M. Mitochondrial DNA and human evolutioN. Annu Rev Genomics Hum Genet [S.I.], v. 6, p. 165-83, 2005.

PANTE-DE-SOUSA, G. et al. Origin of the hemoglobin S gene in a northern Brazilian population: the combine effects of slave trade and internal migrations. Genetics and Molecular Biology [S.I.], v. 21, p. 1415-4757, 1998.

PARRA, F. C. et al. Color and genomic ancestry in Brazilians. Proc Natl Acad Sci U S A [S.I.], v. 100, n. 1, p. 177-82, Jan 72003.

PARSONS, T. J.; COBLE, M. D. Increasing the forensic discrimination of mitochondrial DNA testing through analysis of the entire mitochondrial DNA genome. Croat Med $J$ [S.I.], v. 42, n. 3, p. 304-9, Jun 2001.

PENA, S. D. J. et al. Retrato Molecular do Brasil. Ciência Hoje [S.I.], v. 27, n. 159, p. 16$25,2000$.

A major founder Y-chromosome haplotype in Amerindians. Nature Genetics [S.I.], v. 11, p. 15-16, 1995.

PEREIRA, L. et al. Prehistoric and historic traces in the mtDNA of Mozambique: Insights into the Bantu expansions and the slave trade. Annals of Human Genetics [S.I.], v. 65, p. 439-458, 2001.

. Diversity of mtDNA lineages in Portugal: not a genetic edge of European variation. Ann Hum Genet [S.I.], v. 64, n. Pt 6, p. 491-506, Nov 2000.

PIMENTA, J. R. et al. Color and genomic ancestry in Brazilians: a study with forensic microsatellites. Hum Hered [S.I.], v. 62, n. 4, p. 190-5, 2006.

PLAZA, S. et al. Insights into the western Bantu dispersal: mtDNA lineage analysis in Angola. Hum Genet [S.I.], v. 115, n. 5, p. 439-47, Oct 2004.

QUINTANA-MURCI, L. et al. Maternal traces of deep common ancestry and asymmetric gene flow between Pygmy hunter-gatherers and Bantu-speaking farmers. Proc Natl Acad Sci U S A [S.I.], v. 105, n. 5, p. 1596-601, Feb 52008.

Genetic evidence of an early exit of Homo sapiens sapiens from Africa through eastern Africa. Nature Genetics [S.I.], v. 23, p. 437-441, 1999. 
RANDO, J. C. et al. Mitochondrial DNA analysis of northwest African populations reveals genetic exchanges with European, near-eastern, and sub-Saharan populations. Ann Hum Genet [S.I.], v. 62, n. Pt 6, p. 531-50, Nov 1998.

REIDLA, M. et al. Origin and diffusion of mtDNA haplogroup X. Am J Hum Genet [S.I.], v. 73, n. 5, p. 1178-90, Nov 2003.

RENFREW, C.; BOYLE, K. Archeogenetics: DNA and the population prehistory of Europe. Cambridge: McDonald Institute for Archaeological Research 2000.

RIBEIRO, D. O povo brasileiro: a formação e o sentido do Brasil. São Paulo, Brasil: Companhia das Letras, 1995.

RIBEIRO-DOS-SANTOS, A. K. et al. Nucleotide variability of HV-I in Afro-descendents populations of the Brazilian Amazon Region. Forensic Sci Int [S.I.], v. 167, n. 1, p. 77-80, Mar 222007.

. The split of the Arara population: comparision of genetic drift and founder effect. Human Heredity [S.I.], v. 51, p. 79-84, 2001.

Dissimilarities in the process of formation of Curiau, a semi-isolated AfroBrazilian population of the Amazon region. Am J Hum Biol [S.I.], v. 14, n. 4, p. 440-7, JulAug 2002.

RODRIGUEZ-DELFIN, L. et al. Diversity of the human Y chromosome of South American Amerindians: a comparison with blacks, whites, and Japanese from Brazil. Ann Hum Genet [S.I.], v. 61, n. Pt 5, p. 439-48, Sep 1997.

RODRIGUEZ-DELFIN, L. A. et al. Genetic diversity in an Andean population from Peru and regional migration patterns of Amerindians in South America: data from Y chromosome and mitochondrial DNA. Hum Hered [S.I.], v. 51, n. 1-2, p. 97-106, 2001.

ROSA, A. et al. MtDNA profile of West Africa Guineans: towards a better understanding of the Senegambia regioN. Ann Hum Genet [S.I.], v. 68, N. Pt 4, p. 340-52, Jul 2004.

ROSENBERG, N. A. et al. Genetic structure of human populations. Science [S.I.], v. 298, n. 5602, p. 2381-5, Dec 202002.

ROZAS, J. et al. DNA Polymorphism analysis by the coalescent and other methods. Bioinformatics [S.I.], v. 19, p. 2496-2497, 2003.

RUIZ-PESINI, E. et al. An enhanced MITOMAP with a global mtDNA mutational phylogeny. Nucleic Acids Res [S.I.], v. 35, n. Database issue, p. D823-8, Jan 2007.

SAILLARD, J. et al. mtDNA variation among Greenland Eskimos: the edge of the Beringian expansion. Am J Hum Genet [S.I.], v. 67, n. 3, p. 718-26, Sep 2000. 
SAITOU, N.; NEI, M. The neighbour-joining method: a new method for reconstructing phylogenetic trees. Molecular Biology and Evolution [S.I.], v. 4, p. 406-425, 1987.

SALAS, A. et al. The making of the African mtDNA landscape. Am J Hum Genet [S.I.], v. 71, n. 5, p. 1082-111, Nov 2002.

The African diaspora: mitochondrial DNA and the Atlantic slave trade. Am J Hum Genet [S.I.], v. 74, n. 3, p. 454-65, Mar 2004.

SALZANO, F. M. Human races: myth, invention or reality? Interciência [S.I.], v. 22, p. 221-227, 1997a.

Molecular variability in Amerindians: widespread but uneven information. An Acad Bras Cienc [S.I.], v. 74, n. 2, p. 223-63, Jun 2002.

SALZANO, F. M. et al. Blood genetic systems in four Amazonian tribes. Am J Phys Anthropol [S.I.], v. 85, n. 1, p. 51-60, May 1991.

SALZANO, F. M.; CALLEGARI-JACQUES, S. M. Amerindian and nonAmerindian autosome molecular variability--a test analysis. Genetica [S.I.], v. 126, n. 1-2, p. 237-42, Jan 2006.

SALZANO, F. M. et al. The Brazilian Xavante Indians revisited: new protein genetic studies. Am J Phys Anthropol [S.I.], v. 104, n. 1, p. 23-34, Sep 1997 b.

SALZANO, F. M.; FREIRE-MAIA, N. Populações brasileiras, aspectos demográficos, genéticos e antropológicos. São Paulo, Brasil: Companhia Editora Nacional, 1967.

. Problems in Human Biology. A Study of Brazilian Populations. Detroit, USA: Wayne State University Press, 1970.

SAlZANO, F. R.; CALlEGARI-JACQUES, S. M. South Americans. A Case Study in EvolutioN. New York, USA: Claredon Press, Oxford, 1988.

SAMBROOK, J. et al. Molecular cloning: A laboratory manual. New York, USA: Cold Spring Harbor Press, 1989.

SANS, M. Admixture studies in Latin America: from the 20th to the 21st century. Human Biology [S.I.], v. 72, p. 155-177, 2000.

SANTOS, F. R. et al. The central Siberian origin for native American Y chromosomes. Am J Hum Genet [S.I.], v. 64, n. 2, p. 619-28, Feb 1999.

Genetic and population study of a Y-linked tetranucleotide repeat DNA polymorphism with a simple non-isotopic technique. Hum Genet [S.I.], v. 90, n. 6, p. 6556, Feb 1993. 
SANTOS, S. E. et al. Multiple founder haplotypes of mitochondrial DNA in Amerindians revealed by RFLP and sequencing. Ann Hum Genet [S.I.], v. 60, n. Pt 4, p. 305-19, Jul 1996.

SCHEFFLER, I. E. Mitochondria. New York, USA: Wiley-Liss, 1999.

A century of mitochondrial research: achievements and perspectives Mitochondrion [S.I.], v. 1, n. 1, p. 3-31, 2001.

SCHMITT, R. et al. Extremely limited mitochondrial DNA variability among the Aché Natives of Paraguay. Annals of Human Biology [S.I.], v. 31, p. 87-94, 2004.

SCHMITZ, P. I.; BECKER, I. I. B. Os primitives engenheiros do planalto e suas estruturas subterrâneas: a tradição Taquara. In: Kern A, editor. Arqueologia pré-histórica do Rio Grande do Sul. Porto Alegre, Brasil: Mercado Aberto, 1997.

SCHNEIDER, H. et al. Isolate breakdown in Amazonia. The blacks of the Trombetas river. Revista Brasileira de Genética [S.I.], v. 10, p. 565-574, 1987.

SCHNEIDER, S. et al. Arlequin (ver 2000) - a software for population genetic data analysis. Geneva: University of Geneva, 2000.

SCHURR, T. G. The peopling of the new world: perspectives from molecular anthropology. Annual Review of Anthropology [S.I.], v. 33, p. 551-583, 2004.

SCHURR, T. G. et al. Amerindian mitochondrial DNAs have rare Asian mutations at high frequencies, suggesting they derived from four primary maternal lineages. Am J Hum Genet [S.I.], v. 46, n. 3, p. 613-23, Mar 1990.

SCHURR, T. G.; SHERRY, S. T. Mitochondrial DNA and Y chromosome diversity and the peopling of the Americas: evolutionary and demographic evidence. Am J Hum Biol [S.I.], v. 16, n. 4, p. 420-39, Jul-Aug 2004.

SCHWARTZ, M.; VISSING, J. Paternal inheritance of mitochondrial DNA. N Engl J Med [S.I.], v. 347, n. 8, p. 576-80, Aug 222002.

. New patterns of inheritance in mitochondrial disease. Biochemical and Biophysical Research Communications [S.I.], v. 310, p. 247-251, 2003.

SHEN, P. et al. Reconstruction of patrilineages and matrilineages of Samaritans and other Israeli populations from Y-chromosome and mitochondrial DNA sequence variation. Hum Mutat [S.I.], v. 24, n. 3, p. 248-60, Sep 2004.

SHITARA, H. et al. Maternal inheritance of mouse mtDNA in interspecific hybrids: segregation of the leaked paternal mtDNA followed by the prevention of subsequent paternal leakage. Genetics [S.I.], v. 148, N. 2, p. 851-7, Feb 1998. 
SILVA, W. A. et al. mtDNA haplogroups analysis of black brazilian and sub-saharan populations: Implications for the atlantic slave trade. Human Biology [S.I.], v. 78, p. 29-41, 2006.

SILVA, W. A. J. et al. Mitochondrial genome diversity of Native Americans supports a single and early entry of founder populations into América. American Journal of Human Genetic [S.I.], v. 72, p. 1346-1348, 2002.

SLATKIN, M.; HUDSON, R. R. Pairwise comparisons of mitochondrial DNA sequence in stable and exponentially growing populations. Genetics [S.I.], v. 129, p. 555-562, 1991.

SOODYALL, H. et al. mtDNA control-region sequence variation suggests multiple independent origins of an "Asian-specific" 9-bp deletion in sub-Saharan Africans. Am J Hum Genet [S.I.], v. 58, n. 3, p. 595-608, Mar 1996.

STONEKING, M.; SOODYALL, H. Human evolution and the mitochondrial genome. Curr Opin Genet Dev [S.I.], v. 6, N. 6, p. 731-6, Dec 1996.

SUTOVSKY, P. et al. Ubiquitin tag for sperm mitochondria. Nature [S.I.], v. 402, n. 6760, p. 371-2, Nov 251999.

Ubiquitinated sperm mitochondria, selective proteolysis, and the regulation of mitochondrial inheritance in mammalian embryos. Biol Reprod [S.I.], v. 63, n. 2, p. 582-90, Aug 2000.

SZATHMARY, E. J. mtDNA and the peopling of the Americas. Am J Hum Genet [S.I.], v. 53, N. 4, p. 793-9, Oct 1993.

TAMM, E. et al. Beringian standstill and spread of Native American founders. PLoS ONE [S.I.], v. 2, N. 9, p. e829, 2007.

TARAZONA-SANTOS, E. et al. Genetic differentiation in South Amerindians is related to environmental and cultural diversity: evidence from the Y chromosome. Am J Hum Genet [S.I.], v. 68, N. 6, p. 1485-96, Jun 2001.

TARAZONA-SANTOS, E.; SANTOS, F. R. The peopling of the Americas: a second major migration? Am J Hum Genet [S.I.], v. 70, N. 5, p. 1377-80; author reply 1380-1, May 2002.

TAYLOR, R. W. et al. Genotypes from patients indicate no paternal mitochondrial DNA contributioN. Ann Neurol [S.I.], v. 54, N. 4, p. 521-4, Oct 2003.

TETZLAFF, S. et al. Mitochondrial DNA population data of HVS-I and HVS-II sequences from a northeast German sample. Forensic Sci Int [S.I.], v. 172, N. 2-3, p. 218-24, Oct 25 2007. 
THYAGARAJAN, B. et al. Mammalian mitochondria possess homologousDNArecombination activity. Journal of Biological Chemistry [S.I.], v. 271, p. 27536-27543, 1996.

TORRONI, A. et al. Classification of European mtDNAs from an analysis of three European populations. Genetics [S.I.], v. 144, N. 4, p. 1835-50, Dec 1996.

Mitochondrial DNA "clock" for the Amerinds and its implications for timing their entry into North America. Proc Natl Acad Sci U S A [S.I.], v. 91, N. 3, p. 1158-62, Feb 1 1994.

Asian affinities and continental radiation of the four founding Native American mtDNAs. Am J Hum Genet [S.I.], v. 53, N. 3, p. 563-90, Sep 1993.

Native American mitochondrial DNA analysis indicates that the Amerind and the Nadene populations were founded by two independent migrations. Genetics [S.I.], v. 130, n. 1, p. 153-62, Jan 1992.

TORRONI, A.; WALlACE, D. C. MtDNA haplogroups in Native Americans. Am J Hum Genet [S.I.], v. 56, n. 5, p. 1234-8, May 1995.

TROVOADA, M. J. et al. Pattern of mtDNA variation in three populations from Sao Tome e Principe. Ann Hum Genet [S.I.], v. 68, n. Pt 1, p. 40-54, Jan 2004.

UMETSU, K.; YUASA, I. Recent progress in mitochondrial DNA analysis. Leg Med (Tokyo) [S.I.], v. 7, n. 4, p. 259-62, Jul 2005.

UNDERHILL, P. A.; KIVISILD, T. Use of y chromosome and mitochondrial DNA population structure in tracing human migrations. Annu Rev Genet [S.I.], v. 41, p. 539-64, 2007.

UNDERHILL, P. A. et al. The phylogeography of Y chromosome binary haplotypes and the origins of modern human populations. Ann Hum Genet [S.I.], v. 65, n. Pt 1, p. 43-62, Jan 2001.

Y chromosome sequence variation and the history of human populations. Nat Genet [S.I.], v. 26, n. 3, p. 358-61, Nov 2000.

URBAN, G. A história da cultura brasileira segundo as línguas nativas. In: Carneiro da Cunha MC, editor. Historia dos índios no Brasil. São Paulo, Brasil: Companhia das Letras, 1998.

VAINFAS, R. Dicionário do Brasil colonial. Rio de Janeiro, Brasil: Editora Objetiva, 2000.

VAN HOLST PELLEKAAN, S. M. et al. Mitochondrial genomics identifies major haplogroups in Aboriginal Australians. Am J Phys Anthropol [S.I.], v. 131, n. 2, p. 282-94, Oct 2006. 
VIGILANT, L. et al. African populations and the evolution of human mitochondrial DNA. Science [S.I.], v. 253, n. 5027, p. 1503-7, Sep 271991.

VOGEL, F.; MOTULSKY, A. G. Human Genetics. Seattle, WA, USA: University of Washington, 2000.

WAGNER, S. C. et al. Caracterização molecular da anemia falciforme em pacientes de Porto Alegre. Revista Brasileira de Genética [S.I.], v. 19, p. 244, 1996.

WALLACE, D. C. Mitochondrial defects in cardiomyopathy and neuromuscular disease. Am Heart J [S.I.], v. 139, n. 2 Pt 3, p. S70-85, Feb 2000.

- A mitochondrial paradigm of metabolic and degenerative diseases, aging, and cancer: a dawn for evolutionary medicine. Anпu Rev Genet [S.I.], v. 39, p. 359-407, 2005.

. Why do we still have a maternally inherited mitochondrial DNA? Insights from evolutionary medicine. Annu Rev Biochem [S.I.], v. 76, p. 781-821, 2007.

WALLACE, D. C. et al. Mitochondrial DNA variation in human evolution and disease. Gene [S.I.], v. 238, n. 1, p. 211-30, Sep 301999.

- Dramatic founder effects in Amerindian mitochondrial DNAs. Am J Phys Anthropol [S.I.], v. 68, n. 2, p. 149-55, Oct 1985.

WALLACE, D. C.; TORRONI, A. American Indian prehistory as written in the mitochondrial DNA: a review. Human Biology [S.I.], v. 64, p. 403-416, 1992.

WANG, S. et al. Genetic Variation and Population Structure in Native Americans. PLOS Genetics [S.I.], v. 3, n. 11, p. e185, 2007.

WARD, R. H. et al. Genetic and linguistic differentiation in the Americas. Proc Natl Acad Sci U S A [S.I.], v. 90, n. 22, p. 10663-7, Nov 151993.

. Mitochondrial DNA polymorphism in three Brazilian tribes. American Journal of Human Biology [S.I.], v. 8, p. 317-323, 1996.

WATSON, E. et al. Mitochondrial footprints of human expansions in Africa. Am J Hum Genet [S.I.], v. 61, n. 3, p. 691-704, Sep 1997.

WONG, H. Y. et al. Sequence polymorphism of the mitochondrial DNA hypervariable regions I and II in 205 Singapore Malays. Leg Med (Tokyo) [S.I.], v. 9, n. 1, p. 33-7, Jan 2007.

WRIGHT, S. The genetical structure of populations. Annals of Eugenics [S.I.], v. 15, p. 323-354, 1951. 
YAO, Y. G. et al. A call for mtDNA data quality control in forensic science. Forensic Sci Int [S.I.], v. 141, N. 1, p. 1-6, Apr 202004.

Phylogeographic differentiation of mitochondrial DNA in Han Chinese. Am J Hum Genet [S.I.], v. 70, N. 3, p. 635-51, Mar 2002.

ZAGO, M. A. et al. Bantu beta s cluster haplotype predominates among Brazilian blacks. Am J Phys Anthropol [S.I.], v. 88, N. 3, p. 295-8, Jul 1992.

ZHANG, Y. et al. Haplotype diversity in mitochondrial DNA hypervariable region I, II and III in a Korean ethnic group from northeast China. Forensic Sci Int [S.I.], v. 151, n. 2-3, p. 299-301, Jul 162005.

\section{Web sites consultados:}

Centro de Cartografia Aplicada e Informação Geográfica - UNB. Acesso: 08/08/2009.

Fundação Instituto de Terras do Estado de São Paulo. Acesso: 06/08/2008.

Fundação Nacional do Índio - FUNAI. Acesso: 08/08/2009.

The Genographic Project. Acesso: 06/08/2009.

Governo do Estado de São Paulo. Acesso: 06/08/2009.

Human Genomic Diversity Project. Acesso: 06/08/2009.

Instituto Brasileiro de Geografia e Estatística. Acesso: 06/08/2009.

ISA - Instituto Socio Ambiental. Acesso: 06/08/2009.

MITOMAP - A Human Mitochondrial Genome Database. Acesso: 06/08/2009.

Programa das Nações Unidas para o Desenvolvimento. Acesso: 08/08/2009.

Programa das Nações Unidas para o Desenvolvimento. Acesso: 15/09/2009.

Stanford University - Morrison Institute. Acesso: 08/08/2009. 


\section{ANEXO I}

Matrizes de distância genética $F s t$ entre as populações remanescente de quilombos do Vale do Ribeira, uma amostra da cidade de São Paulo e populações referência. 
Tabela V - Matriz de distâncias genéticas Fst entre as comunidades remanescentes de quilombos do Vale do Ribeira e uma amostra da cidade de São Paulo.

$\begin{array}{llllllllllllll}\text { Populações } & 1 & 2 & 3 & 4 & 5 & 6 & 7 & 8 & 9 & 10 & 11 & 12 & 13\end{array}$

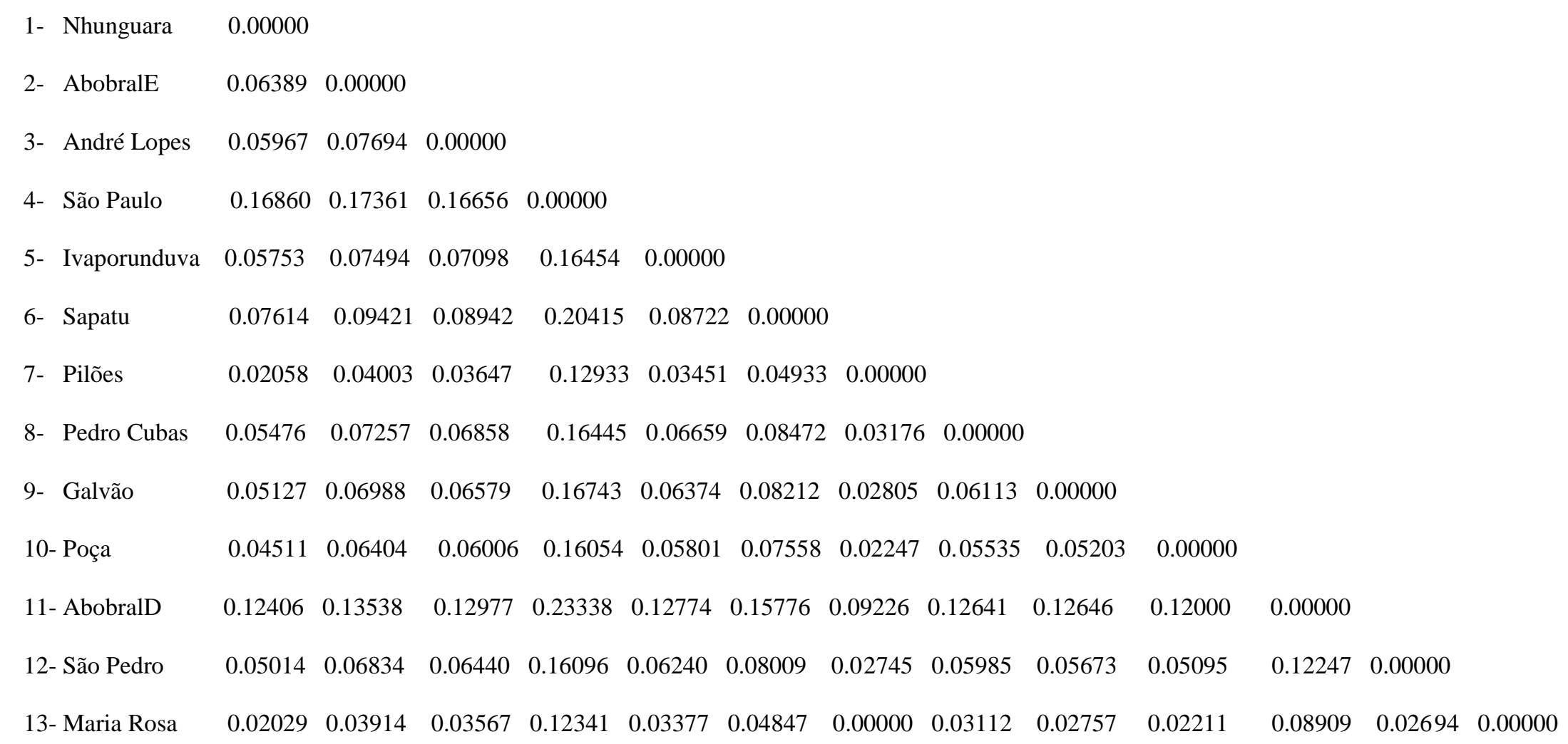


Tabela VI - Matriz de distâncias Fst entras as comunidades remanescentes de quilombos, uma amostra de São Paulo e populações referência.

\begin{tabular}{|c|c|c|c|c|c|c|c|c|c|c|c|c|c|c|c|c|c|c|}
\hline Populações & 1 & 2 & 3 & 4 & 5 & 6 & 7 & 8 & 9 & 10 & 11 & 11 & 12 & 13 & 14 & 16 & 17 & 18 \\
\hline 1- São Paulo & 0.00000 & & & & & & & & & & & & & & & & & \\
\hline 2- Pedro Cubas & 0.06389 & 0.00000 & & & & & & & & & & & & & & & & \\
\hline 3- Pilões & 0.05967 & 0.07694 & 0.00000 & & & & & & & & & & & & & & & \\
\hline 4- Sapatu & 0.16860 & 0.17361 & 0.16656 & 0.00000 & & & & & & & & & & & & & & \\
\hline 5- Maria Rosa & 0.05753 & 0.07494 & 0.07098 & 0.16454 & 0.00000 & & & & & & & & & & & & & \\
\hline 6- Nhunguara & 0.07614 & 0.09421 & 0.08942 & 0.20415 & 0.08722 & 0.00000 & & & & & & & & & & & & \\
\hline 7- Banto & 0.02058 & 0.04003 & 0.03647 & 0.12933 & 0.03451 & 0.04933 & 0.00000 & & & & & & & & & & & \\
\hline 8- Afro-Brasileiros & 0.05476 & 0.07257 & 0.06858 & 0.16445 & 0.06659 & 0.08472 & 0.03176 & 0.00000 & & & & & & & & & & \\
\hline 9- Ameríndio & 0.05127 & 0.06988 & 0.06579 & 0.16743 & 0.06374 & 0.08212 & 0.02805 & 0.06113 & 0.00000 & & & & & & & & & \\
\hline 10- Poça & 0.04511 & 10.06404 & 0.06006 & 60.16054 & 0.05801 & 0.07558 & 0.02247 & $7 \quad 0.05535$ & 0.05203 & 30.00000 & & & & & & & & \\
\hline 11- André Lopes & 0.12406 & 50.13538 & 0.12977 & $7 \quad 0.23338$ & 0.12774 & $4 \quad 0.15776$ & 50.09226 & $\begin{array}{ll}6 & 0.12641\end{array}$ & 10.12646 & 60.12000 & 0.00000 & & & & & & & \\
\hline 12- Galvão & 0.05014 & 0.06834 & 0.06440 & 0.16096 & 0.06240 & 0.08009 & 0.02745 & $5 \quad 0.05985$ & 0.05673 & $\begin{array}{ll}3 & 0.05095\end{array}$ & 50.12247 & $7 \quad 0.00000$ & & & & & & \\
\hline 13- AbobralD & 0.02029 & 0.03914 & 0.03567 & 0.12341 & 0.03377 & 0.04847 & 0.00000 & 0.03112 & 0.02757 & $7 \quad 0.02211$ & 10.08909 & 90.02694 & 40.00000 & & & & & \\
\hline 14- AbobralE & 0.09922 & 0.11366 & 0.10946 & 0.19371 & 0.10764 & 0.12847 & 0.07463 & 0.10577 & 0.10396 & 0.09837 & 0.16245 & 0.10195 & 0.07269 & 90.00000 & & & & \\
\hline 15- Brasileiros Brancos & 0.02061 & 0.03881 & 0.03537 & 0.11844 & 0.03354 & 0.04838 & 0.00051 & 0.03104 & 0.02769 & 0.02233 & 0.08678 & 80.02700 & 0.00051 & 10.06933 & 0.00000 & & & \\
\hline 16- Portugueses & 0.02307 & 0.04139 & 0.03793 & 0.12263 & 0.036080 & 0.05102 & 0.00279 & 0.03354 & 0.03015 & 0.02475 & 0.09006 & 0.02945 & 0.00276 & 50.07342 & 0.00324 & 0.00000 & & \\
\hline 17- São Pedro & 0.02059 & 0.03884 & 0.03539 & 0.11879 & 0.033560 & 0.04838 & 0.00048 & 0.03105 & 0.02768 & 0.02232 & 0.08695 & 0.02700 & 0.00048 & 0.06975 & 0.00098 & 0.00321 & 0.00000 & \\
\hline 18- Ivaporunduva & 0.02008 & 0.03836 & 0.03491 & 0.11831 & $0.03308 \quad 0$ & 0.04787 & 0.00000 & 0.03057 & 0.02719 & 0.02183 & 0.08646 & 0.02652 & 0.00000 & 0.06928 & 0.00051 & 0.00274 & 0.00047 & 000 \\
\hline
\end{tabular}


Tabela VII - Matriz de distâncias Fst entre os grandes grupos populacionais.

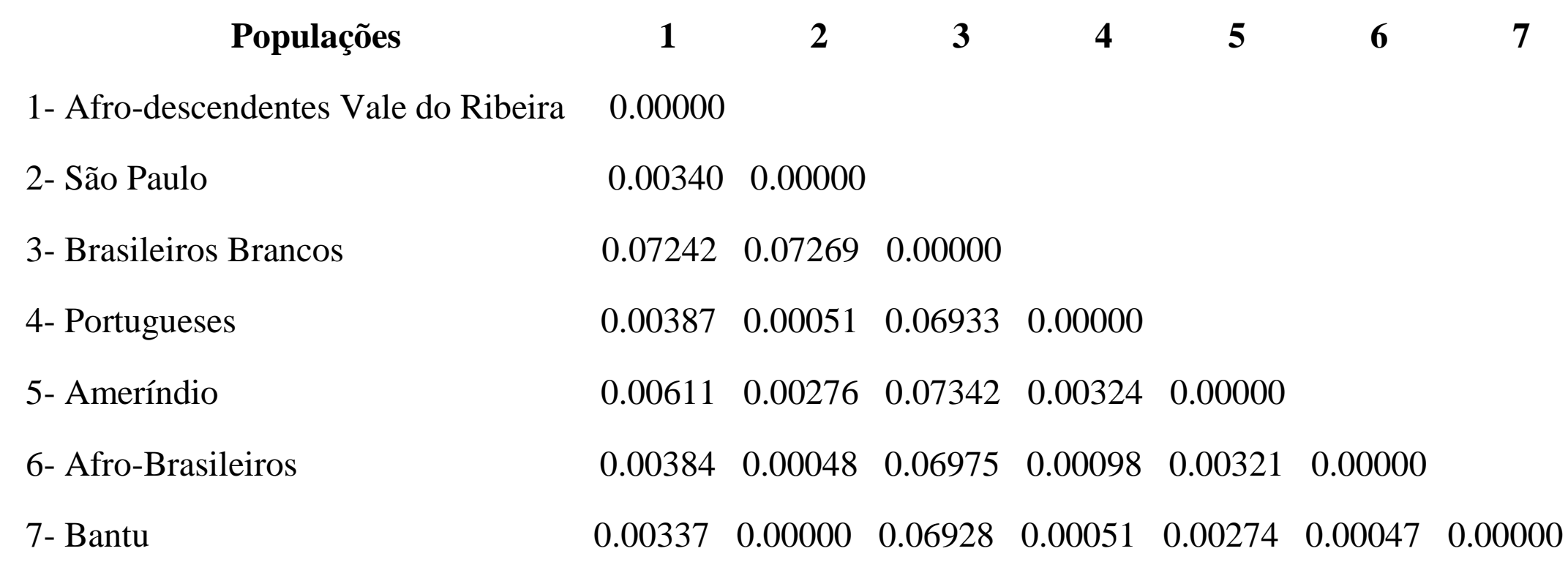

